The Geological Society of America

Special Paper 500

2013

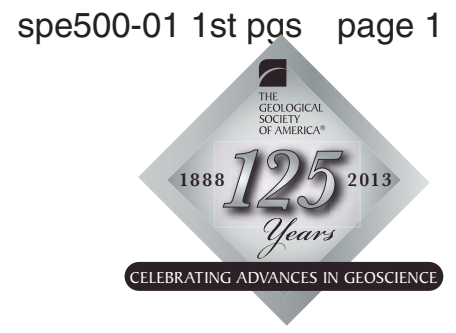

\title{
Plates, planets, and phase changes: 50 years of petrology
}

\author{
David Walker* \\ Department of Earth and Environmental Sciences, Lamont-Doherty Earth Observatory, \\ Columbia University, Palisades, New York 10964, USA
}

\begin{abstract}
Three advances of the previous half-century fundamentally altered petrology, along with the rest of the Earth sciences. Planetary exploration, plate tectonics, and a plethora of new tools all changed the way we understand, and the way we explore, our natural world. And yet the same large questions in petrology remain the same large questions. We now have more information and understanding, but we still wish to know the following. How do we account for the variety of rock types that are found? What does the variety and distribution of these materials in time and space tell us? Have there been secular changes to these patterns, and are there future implications? This review examines these bigger questions in the context of our new understandings and suggests the extent to which these questions have been answered. We now do know how the early evolution of planets can proceed from examples other than Earth, how the broad rock cycle of the present plate tectonic regime of Earth works, how the lithosphere atmosphere hydrosphere and biosphere have some connections to each other, and how our resources depend on all these things. We have learned that small planets, whose early histories have not been erased, go through a wholesale igneous processing essentially coeval with their formation. By inference, this also happened to Earth. The early differentiation on a small planet produces observable basaltic rock types-and produces little else besides a residue and a planetary core. In contrast, the larger Earth's preservation of its original differentiation products has been eroded by continued activity which still involves extensive basaltic volcanism with further reprocessing through plate tectonic cycles to form continents and cratons. We also now have a good understanding of the pressure-induced phase changes that are responsible for the Earth's mantle's seismic layered structure. It is unclear the extent to which this layered seismic structure corresponds to chemical layering as well as to mineralogical layering. Earth's transition zone, lower, and upper mantles may not have the same composition. It is possible that still larger exoplanets might be expected to develop additional modes of activity with emphasis on additional phase changes producing more internal layering and differentiation.
\end{abstract}

\footnotetext{
*dwalker@1deo.columbia.edu
}

Walker, D., 2013, Plates, planets, and phase changes: 50 years of petrology, in Bickford, M.E., ed., The Web of Geological Sciences: Advances, Impacts, and Interactions: Geological Society of America Special Paper 500, p. 1-32, doi:10.1130/2013.2500(01). For permission to copy, contact editing @ geosociety.org. @ 2013 The Geological Society of America. All rights reserved. 


\section{INTRODUCTION}

I am honored to have been asked to participate in this celebration of 125 years of the Geological Society of America. But I am daunted by the thought that I could do full justice in a single article to the past 50 years of petrology, or for that matter to any of the subdisciplines of the geological sciences that have been essentially rewritten from the developments of the past 50 years. Whole textbooks have recently been devoted to petrology alone (Hess, 1989; Best, 2003; Philpotts and Ague, 2009; Gill, 2010). Therefore for the purposes of this review, petrology is restricted to the study of the processes that cause the differentiation of the terrestrial planets from which we have samples. These are mostly igneous processes, but this review will also explore the subject of mantle phase changes, not because they are necessarily igneous, but because they are felt to be useful to an understanding of our planet's cumulative differentiation and evolution. The metamorphic and sedimentary aspects of the rock cycle that does the differentiation have their own highlights in the past half century and are covered in other articles in this volume. I hope this limited view of petrology will offend as few as possible and that my participation over the past 40 years in this subset of the discipline will serve as an excuse for such a selective review.

\section{THREE REVOLUTIONS IN WHICH PETROLOGY WAS ENTRAINED}

The plate tectonics revolution in our understanding of how the Earth works gave contextual significance to the occurrence and distribution of the variety of terrestrial rocks that was already well known (Wyllie, 1973). Petrology was a mature field with many volumes written about the variety and occurrence of igneous rocks (e.g., Johannsen, 1939). It was analogous to botany and zoology before Darwin. Our new understanding that the Earth's surface tectonics could be viewed in terms of the motions of a few large semi-rigid, cap-like plates being dragged about on the underlying lubricant of significantly weaker material, is intimately tied to our current picture of the mid-oceanic-ridge basalt (MORB)-to-arc cycle of crust building by igneous (and metamorphic) rock-forming processes. The crust-building processes are largely concentrated along plate margins. The relatively simple, voluminous MORB volcanism of divergent margins building oceanic crust, is complemented by the relatively more complex arc volcanism associated with subduction and plate consumption at convergent margins that leads to continental growth. The stabilization of continental cratons may or may not be part of this modern tectonic cycle. Intraplate volcanism, with or without plumes, is further understood as an ancillary expression of the convective motions of the mobile interior of the Earth in its quest to eliminate thermal imbalances. Thermal imbalances lead to buoyant rise and decompression partial melting of peridotite material that drives crust-forming volcanism. The products of melting in both magmatic types of plate margins, and also within plates, are skewed heavily to basaltic volcanism.
This reflects the importance of olivine-rich materials (peridotites) as the feed-stocks of melting throughout the upper mantle. Differences between the melting products in different tectonic environments reflect both the differences in source materials feeding the decompression melting in those various environments (i.e., modal mineralogy and extent of recycled contaminants), as well as the nature (temperature, extent, depth, moisture content, etc.) of the melting process. The plate tectonic framework for our new understandings did not exist before the half-century covered by this review, even though various bits and pieces such as the importance of peridotite, decompression melting, and general rock associations were well known.

The second revolution in which petrology was entrained began about the time of the fall of the Allende meteorite in February of 1969. A couple of tons of extraterrestrial material was recovered for study from a wide strewn field in the Mexican desert. This fall coincided with the final preliminary stages of the NASA Apollo mission to Earth's moon. These two events were the beginning of an exploration of the solar system including landing and sampling missions and robotic exploration of the Moon, Venus, Mars, Mercury, some asteroids, and the outer planets and their moons with flybys. This revolution is ongoing and now includes identification of terrestrial planets in other solar systems. The significance of the Allende meteorite fall is that it occurred at the time when a dedicated section of the petrology community was in a fever of anticipation to have a look at the Apollo sample returns from the moon. The exotic meteorite fall of Allende was in a sense a dry run for the detailed and intensive, and competitive, techniques that were to be used for examination of the Apollo lunar rock samples. Allende was a large fall with many fragments that were widely studied by this intensely focused community. Allende contained an unusually conspicuous population of light-colored nuggets embedded in carbonaceous chondrite, not the most common of meteorites to begin with. These calcium and aluminum-rich inclusions (CAIs) turned out to be as interesting and as significant as the Apollo samples for understanding the original petrology of the solar system - as we shall hear. The standards of detailed petrological characterization of samples enjoyed a quantum leap in the Allende-Apollo era. In some measure, these extraterrestrial samples enjoyed a measure of scrutiny and detailed characterization that was unprecedented for terrestrial rocks. Coordinated teams of collaborating and competing scientists, fueled by NASA support, set new standards for comprehensive and detailed sample characterizations. This was in part a consequence of the third revolution in which petrology was entrained in the past half century-the development and wide dissemination of new tools and resources for petrological research.

One can best appreciate this third change, the introduction of new tools into petrology, by reflecting on the typical substantial petrological studies which might have been published from research undertaken before the era under review. Hess's (1960) monograph on the Stillwater intrusion in Montana, and Carmichael's (1964) study of the Thingmuli volcano in Iceland, are typical of the best studies of this era. There is no mystery why 
these authors were the leaders of their field. They arrived at acute insights no matter what was the nature of their tools. There was careful study of field relations. There was petrographic analysis of thin sections supplemented by a few half-tone plates. There were wet chemical analyses of typical rock specimens and of selected mineral separates. Trace elements and isotopic analyses were a rarity at best, as was any experimental study of the suggested relations inferred from the studies undertaken. Quantitative instrumental analysis would have the output numbers hand-recorded in note books after being read from analog charts. Data reduction was aided by analog adding machine. And global data sets for comparison to the materials under study might have had at most a few dozen analyses and were represented by blobs of points or trend lines on variation diagrams. The manuscripts were typed, and distributed in carbon copy; figures were drawn in India ink with Rapidographs using Leroy drafting templates on Herculene or Bristol board. Single-authored papers were common. I suspect many of these modes of research enterprise are alien to current students, for which we may all be grateful. It is hoped that current investigators can rise to the level of insight produced by the masters of the past who themselves managed to lead the science into the current review period. In contrast to past practices, we currently aggregate (if funded) into consortia on missions, with extensive analytical, theoretical, experimental, and data management computer-based digital support systems that did not exist 50 years ago and whose introduction has fundamentally changed the way we conduct petrological research. Hess and Carmichael played no small part in incubating this transformation. Programs such as Apollo, ocean exploration, and continental drilling and sounding are modern enterprises analogous to the previous century's expedition of the Challenger in that they are only undertaken in a climate of liberal support by organizations considerably larger than the individual bands of explorers or their individual institutions. Examination of rock and mineral samples returned from such missions proceeds by electron microprobe, scanning electron microscope (SEM), X-ray fluorescence (XRF) spectrograph, secondary ion mass spectrometer, automated crystal structure difffractometer, infrared spectrometer, plasma-activated emission spectrographs and mass spectrometers, thermal ionization mass spectrometers, and related instrumentation. Data collection for petrology and mineralogy of major and trace elements and isotopes is performed with precisions and with a rapidity undreamed of 50 years ago. The theoretical underpinnings of the petrological sciences are now considerably more sophisticated and are backed up with much more experimental control than previously enjoyed. It is ironic that the advancements in technologies in the experimental petrology field, especially in our ability to achieve simultaneously high pressures and temperatures, should have contributed to making those developments almost obsolete, except as calibration and confirmation exercises. Indeed it has become almost routine to attack petrological phase relation problems with computational rather than experimental methods through the work of Longhi (1991) in developing MAGPOX, Ghiorso and Sack (1995) in developing the MELTS program, or Connolly (2005) in developing PERPLEX. Furthermore, novel mineral stability has been successfully predicted computationally with ab initio methods (Oganov and Ono, 2004). And computer-based data handling of local and global data sets has made new data more easily manipulated and viewed for comparison with what is already known. The resources available for research in the post-World War II and especially the post-Sputnik era of the National Science Foundation, NASA, the Department of Energy, and the Department of Defense sponsorship of basic and applied research has driven many of these developments. It is difficult to imagine that pre1960 levels of research support could ever have sustained the planetary and terrestrial exploration programs from which so much scientific insight has been derived.

\section{IN THE BEGINNING...}

The geology of Hutton and Playfair had "...no vestige of a beginning." Geological time was delimited through the recorded cycle of crustal disturbances and their erosive removal to form sediments and their subsequent consolidation. Presumably the cycles had to start somehow at some time, but the record was too fragmentary to be able to see clearly beyond a few cycles. This shroud has been dissipated considerably in the past 50 years. Our planets' dimly perceived origins are less obscure. We now believe that the weakly anisotropic $\sim 3 \mathrm{~cm}$ cosmic microwave background is the reverberation of the "big bang" creation of our universe $\sim 13.7 \mathrm{Ga}$ ago. Petrological records of that distant time have not been discovered and it is doubtful whether any exist; solid-states were sparingly encountered until considerable expansion and cooling had overtaken the elementary particles that rushed forth from the void. What is perhaps remarkable is that petrological records of the birth of our solar system at $4.567 \mathrm{Ga}$ do survive, in certain chondritic meteorites, as do mineralogical artifacts of the pre-solar intragalactic dust from which our solar system was accreted in the last third of the universe's history. These materials then are our earliest petrological objects for study.

Presolar grains, that are recognizable as such, are often monomineralic, for instance, diamonds (Lewis et al., 1987), or silicon carbide, graphite, silicon nitride and a few other ultrarefractory materials that can survive processing to eliminate isotopically normal materials (Zinner, 1998). They are not a petrologic assemblage although they could have some relation to the (gaseous) medium surrounding exploding stars older than our sun and the interstellar near-vacuum which provided the materials from which our solar system accreted. (The grains owe their recognizable pre-solar isotopic characteristics, principally in noble gases like Xe and Ne, more to their tenacious survivorship and to physical processes like ion implantation, than to petrological equilibrium processes and accretion.) Furthermore, the earliest recognized presolar grains are not the silicates which comprise most of our planetary materials. Subsequently, rare presolar silicates have been recognized by their oxygen isotope signatures in interplanetary dust particles collected from the stratosphere (Messenger et 
al., 2003) and from the most primitive carbonaceous meteorites (Nagashima et al., 2004; Nguyen and Zinner, 2004). These discoveries were facilitated by the development of nanoSIMS ion probe techniques. The presolar isotopic signatures are found in iron-rich magnesian silicate amorphous materials and minerals. The rarity of surviving presolar grains emphasizes that the materials accreting to the early solar system were mostly (but not completely) digested in the accretion and early nebular stages of the solar system. And accrete they did, with a complex series of processes that are recorded imperfectly in meteorites, especially the chondrites. The Allende meteorite deserves and receives here special status for bringing to the attention of science an assemblage of calcium and aluminum-rich inclusions (CAIs) that appear to be the very earliest petrological relicts of our solar system. Complex assemblages of glass and well-crystallized $\mathrm{Ca}-\mathrm{Al}$ rich mineralsanorthite, mellilite, hibonite, diopside, perovskite, corundum, spinel, hercynite, fassaite, grossular to mention a few-are found (Marvin et al., 1970) as nuggets or as fragments (Fig. 1), some with internally zoned sequences (Wark and Lovering, 1977), within the more normal sooty assemblages of debris that normally constitute this sort of carbonaceous chondrite. Undoubtedly some of these CAI objects may have been observed previously but they were not of such a recognition level as to be mentioned in preAllende popular text books (Mason, 1962) on meteorites.

The reason for the interest in the CAIs is their correspondence in mineralogy to the early crystalline phases that might be expected to condense from a gas of roughly solar nebula composition in a modest pressure range in the neighborhood of a millibar. That a tenuous presolar gas cloud could have been compressed into a disc with this order of magnitude pressure, and a temperature sufficient to evaporate and recondense refractory solids was certainly an explored theme in early solar evolution. Significant chemical fractionation of Ca-Al-Ti refractory components into solids at temperatures approaching full evaporation was predicted to occur at thermodynamic equilibrium (Lord, 1965). Early observers of Allende made the connection between the studies of Lord and the CAI nuggets in Allende (Marvin et al., 1970; Larimer and Anders, 1970; Grossman, 1972; Grossman, 1975). There was initially some uncertainty whether these nuggets represented fractional evaporation residues of presolar materials or fractional condensation products of a fully evaporated solar gas. The former interpretation was largely driven by the discovery of strikingly anomalous oxygen isotopic variations in the CAIs of Allende and other carbonaceous chondrites. This discovery was serendipitous, originating as an attempt to look for the characteristic temperature-sensitive oxygen isotope fractionations used to such good purpose in metamorphic thermometry. If the CAIs were a thermal evaporation/condensation sequence then perhaps oxygen isotopes would assist in recognition of the temperatures involved from the extent of inter-mineral fractionation. Instead of isotopic fractionation on an ${ }^{17} \mathrm{O} /{ }^{16} \mathrm{O}$ versus ${ }^{18} \mathrm{O} /{ }^{16} \mathrm{O}$ slope $\sim 0.52$ line characteristic of normal planetary fractionation processes (like thermal evaporation), Clayton et al. $(1973,1977)$ discovered arrays of slope $\sim 1$ trending toward pure
${ }^{16} \mathrm{O}$. These were interpreted as mixing arrays of surviving presolar, ${ }^{16} \mathrm{O}$-enriched materials that were not homogenized within a gaseous nebula, and thus comprised evaporation residues. The interpretation of survival of presolar nucleosynthesis effects has been challenged by the work of Thiemens and Heidenreich (1983), Thiemens (1999) and coworkers who demonstrated that non-mass-dependent isotopic fractionations could be induced by other processes than nucleosynthesis. If the ${ }^{16} \mathrm{O}$ enrichments can be induced photolytically within the solar system, there is no need to interpret them as pre-solar effects. The current view of the matter is that isotope-selective photodissociation of $\mathrm{CO}$ is responsible (Clayton, 2008), a proposition supported by the discovery during recovery of the NASA Genesis mission collectors that the solar wind has different oxygen isotopic composition from planetary materials. The operation of photolytic effects upon planetary materials does not remove the constraint that the mineral assemblages of the CAIs represent near-complete evaporation/initial condensation temperatures of near-solar gases at pressures of the order $\left( \pm 10^{2}\right)$ of a millibar.

Given that nebular gas did achieve near-complete evaporation temperatures, it is natural to expect that subsequent cooling could lead to fractional condensation sequences. Indeed the recognition by Wark and Lovering (1977) of intricate layered sequences upon the rims of the CAI nuggets is thought to represent just such a condensation stratigraphy. The layers and reaction relations preserved strongly indicate the preservation of down-temperature condensation stratigraphy rather than uptemperature evaporation. The principal issues are whether temperature and time or nebular chemistry or position are the main determinants of the stratigraphy and its variations, and the extent to which a liquid phase was involved (Simon, 2012). Textural interpretation within accepted geological paradigms like relative ages by cross-cutting relationships is key to this and many other studies of this era. Such foundational relationships were slightly cracked by analytical and experimental studies of the formation of porphyries and some recrystallization textures but they still are powerful guidelines if properly interpreted (Walker et al., 1976; Park and Means, 1996).

The timing of the assembly of these initial solar system petrological objects is now exquisitely well known. The discovery of ${ }^{26} \mathrm{Mg}$ anomalies in CAIs, presumably sourced in extinct ${ }^{26} \mathrm{Al}$ (Gray and Compston, 1974; Lee at al., 1976) pushed the formation of the CAIs to within a few million years or so of the last pre-solar nucleosynthesis event in our galactic neighborhood. The aggregation of CAIs is now known from $\mathrm{U} / \mathrm{Pb}$ ages to be $4.567 \mathrm{Ga}$ ago (Amelin et al., 2009). The assembly of additional objects to form the chondrites themselves was a few million years after that.

\section{SMALL PLANETS...LONG, LONG AGO}

The chondrites themselves are undifferentiated in refractory elements with respect to the sun and have remained that way since their formation (Fig. 2), various degrees of metamorphic reconstitution notwithstanding (VanSchmus and Wood, 1967). 
However pieces of several small differentiated planets have been preserved in meteorites, including the iron cores and their erupted and residual silicate complements. These various materials are known to be from different planetary objects from their differences in isotopic and trace element patterns which presumably would have been mixed and homogenized in a planetary meltdown, at least to the extent that homogenization is achieved on Earth. Early studies of $\mathrm{Sr}$ isotopic initial variations of the materials of a range of differentiated meteorites showed that the assembly and differentiation events of their parent planets were closely spaced within a few 10s of millions years near the start of the solar system (Papanastassiou and Wasserburg, 1968). The study more recently of ${ }^{182} \mathrm{~W} /{ }^{184} \mathrm{~W}$ isotope variability left by short-
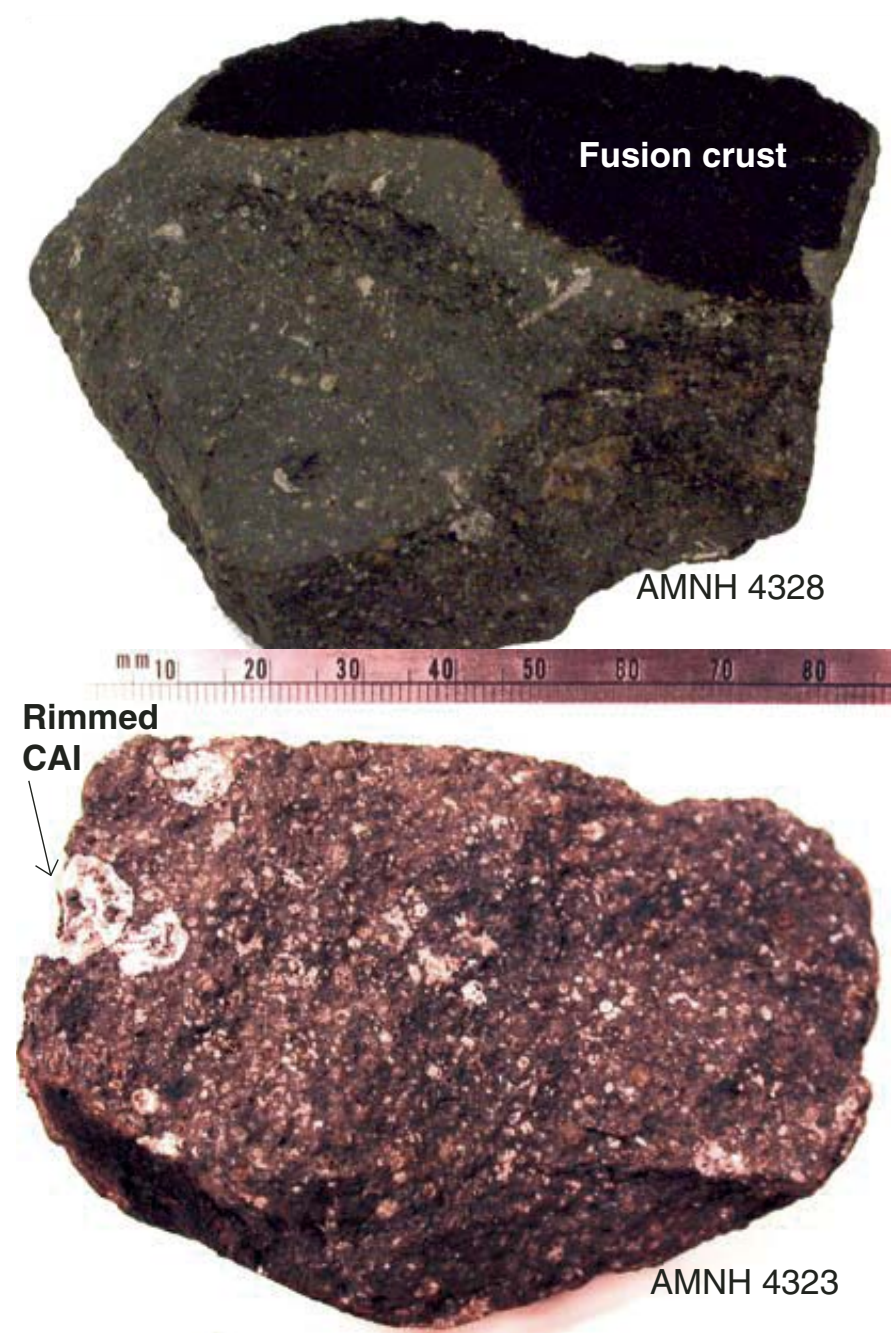

Figure 1. Two Allende meteorite specimen images courtesy of Denton Ebel, American Museum of Natural History. Note heterogeneous distribution of CAIs in carbonaceous chondrite matrix and zoned character of largest CAI visible in lower frame. Mm ruler for scale. Recovery of fragments of this meteorite at the same time that preparations for Apollo lunar sample examination were under way lead to intense scrutiny and recognition of the CAIs and their significance as very early solar system petrology relics. lived and now extinct ${ }^{182} \mathrm{Hf}$ has confirmed the few 10 s of millions of years' time scale for the assembly, differentiation, and cooling of these small objects (Kleine et al., 2002). When one considers that the cooling time scales of iron and stony-iron meteorites are in the range of $1{ }^{\circ} \mathrm{C} / \mathrm{m}$.y. in the range of late evolution of the Widmanstaaten pattern in the interval $600-400{ }^{\circ} \mathrm{C}$, the formation and differentiation of the objects which so slowly cooled subsequently must have been almost immediate following the condensation and accretion of solids (Fig. 3). The early planetesimal objects wasted no time getting down to the business of core formation and initial planetary differentiation. Accretion must not have been a stately process of the gradual accumulation of cold dust and slow heating as once imagined by Urey (1952).
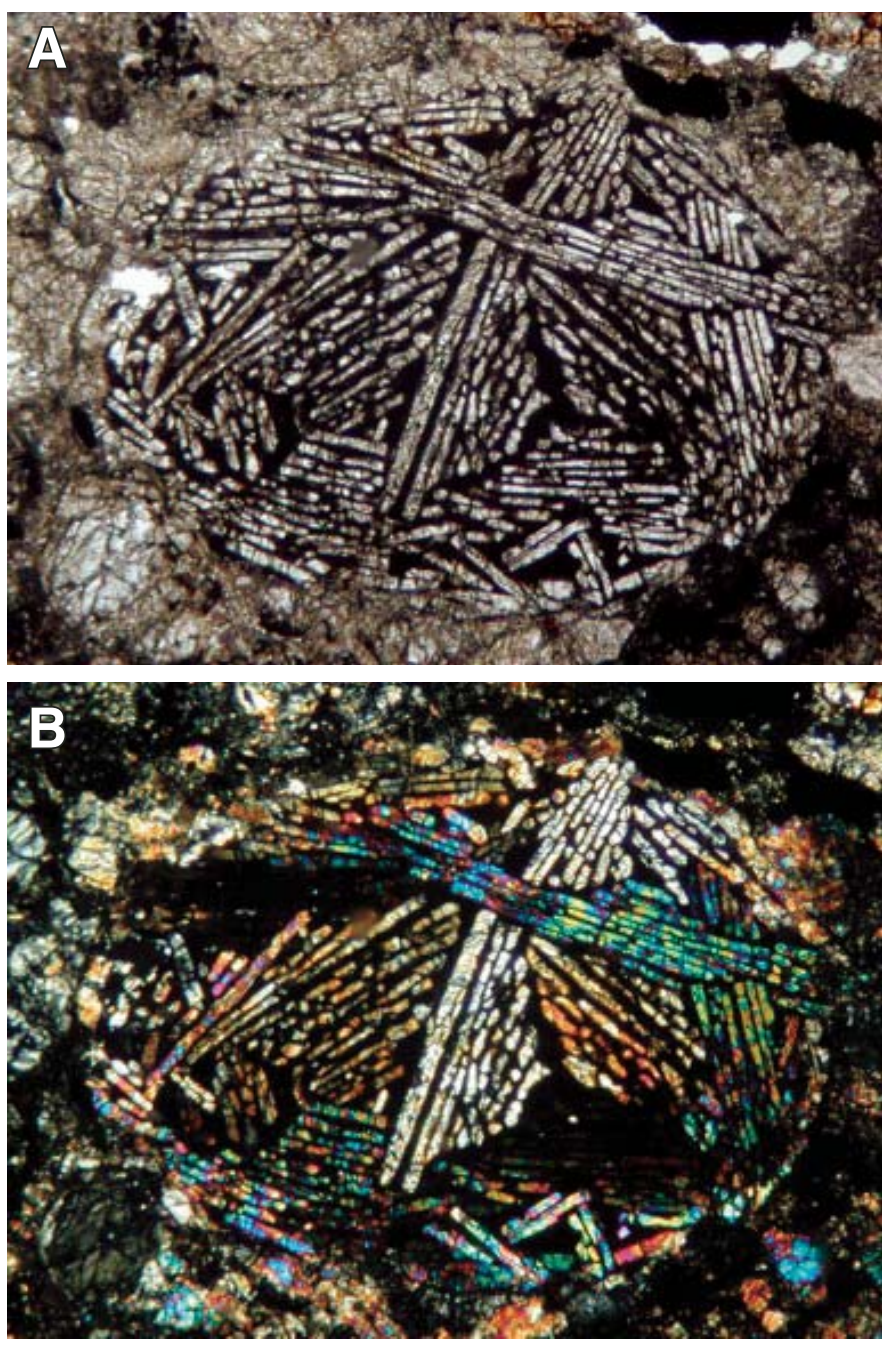

Figure 2. Winnebago meteorite chondrule photomicrographs of a thin section. Vertical dimension of the bean-shaped chondrule is $\sim 1 \mathrm{~mm}$. (A) Plane-polarized illumination. (B) Crossed nicols. Several sprays of olivine are each in optical continuity within a partially devitrified glassy matrix. These objects record the partial crystallization of a silicate liquid rich in olivine, but not necessarily peridotitic. Aggregates of such objects with their cohesive matrix form chondritic meteorites which may approximate the Earth's composition. 
The parent planet of the howardite, eucrite, and diogenite meteorites (HED), three related basaltic achondrite meteorite groups (Duke and Silver, 1967), provide an example of how early planetary differentiation proceeds in the silicate part of a planetesimal. That this planetesimal may still exist in part and be identifiable as the asteroid 4 Vesta was suggested by McCord et al. (1970) from remotely sensed spectral reflectance. The petrologic consequences of this suggestion were most thoroughly explored by Consolmagno and Drake (1977). Extensive dating of the eucrites by Rb-Sr (Papanastassiou and Wasserburg, 1968; Birck and Allègre, 1978), U-Pb (Unruh et al.,1977), and Sm-Nd (Lugmair, 1974; Hamet et al., 1978) methods establishes their magmatic petrogenesis to have occurred $\sim 4550 \mathrm{Ga}$ ago, $\sim 15$ m.y. after the solar system produced its first CAI solid objects. Patchett and Tatsumoto (1980) used this important constraint to calibrate the decay constant for the Lu-Hf chronometer by analysis of these same meteorites. The eucrites show textures and compositions consistent with an origin as the solidified products of magmatic liquid produced by low pressure partial melting of olivine+orthop

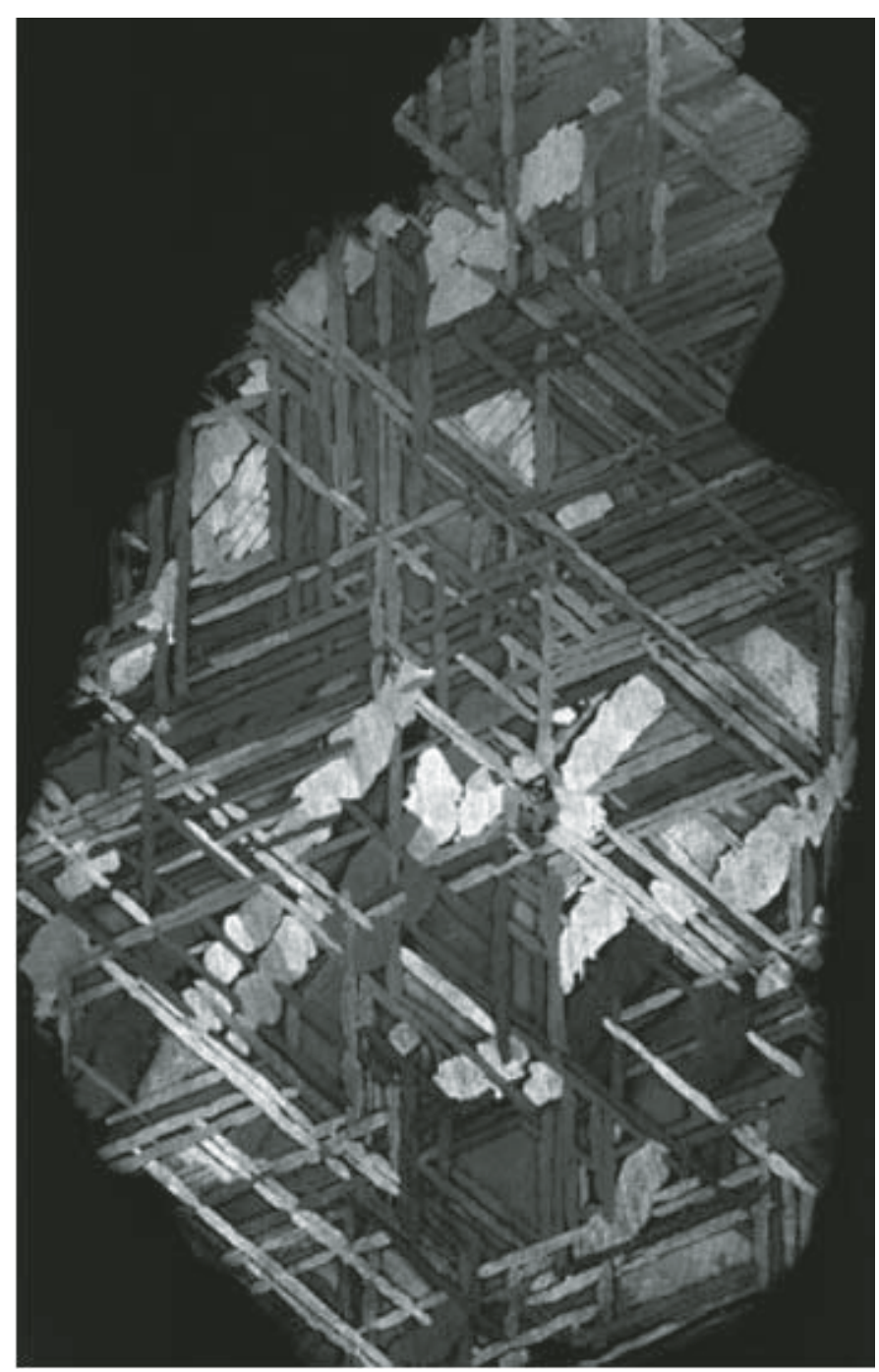

yroxene+plagioclase $+\mathrm{Cr}$-spinel source regions, the sort of mineralogy that could be the expression of primitive chondritic material after recrystallization at low pressure (Stolper, 1977). That liquid eucrites are more probably partial melts than crystallization residues follows from the fact that their compositions are coincident with the peritectic in the system involving olivine, orthopyroxene, and plagioclase as crystalline phases at low pressure (Stolper, 1975). There is no tendency for liquid compositions to cluster at a peritectic, as shown by eucrites, during fractional crystallization as there is during partial melting (Walker et al., 1972; Presnall, 1969). The diogenites are orthopyroxene-rich cumulus-textured rocks probably formed as complementary differentiates of crystallization of eucrite liquids. Howardites are breccias composed of complex mixtures of eucrite and diogenite-like lithologies. Collectively they form an ensemble of complementary rock types that indicate extensive partial melting and magmatic differentiation of the silicate part of a planetesimal from which metal had ”en abstracted to form a core (Stolper, 1975). A substantial part 证 the silicate portion of the planet must have been processed in this magmatic event because primitive undifferentiated materials are not recognized in the howardite breccias which sample several disparate regions of the eucrite parent planet, not including the core. Whether the partial melting ( $\sim 10 \%$ of source region) to form eucrite liquids was extensive enough to form a magma ocean on 4 Vesta is doubtful. Nevertheless the lesson from the eucrite parent planet is that extensive early differentiation was possible and did occur on some bodies in our solar system very soon after the accretion of the first solar system solids. The principal expression of differentiation is partial melting to a modest extent with eruption of the resultant liquids. The eruption provides a heat release valve to prevent thermal runaway with complete planetary meltdown. The parent objects of the chondrites escaped this extreme thermal processing so that mechanisms of heating like extinct radioactivity and/or T Tauri-like episodes of solar eruption that should have processed all materials are less likely determinants of melting than mechanisms that rely on object size to accumulate the heat supplied in some way. Like the

Figure 3. Widmanstaaten texture in polished and etched section of a coarse octahedrite meteorite. Kamacite and taenite iron of low and high $\mathrm{Ni}$ abundances respectively exsolve from one another along (111) crystallographic planes as the core of a small planetary object cooled slowly on the order of 10 s to 1000 s of ${ }^{\circ} \mathrm{C} /$ million years (Wood, 1964; Goldstein and Ogilvie, 1965). The ranges of cooling rates observed from specimens of coeval groups of iron meteorites (Yang et al., 2008) suggests their origin at a variety of depths, with a variety of cooling rates, within poorly-mantled protoplanetary cores that had been stripped of their silicate insulation by collisional processes after core formation. Otherwise their cooling rates would be slower. A more protracted crystallization experiment of this sort is probably in progress in Earth's inner core, except that kamacite and taenite are probably the hexagonal close pack (HCP) form at inner core pressures, the crystals are more likely to be significantly coarser, and to be more thoroughly equilibrated with the rest of the core than are individual meteorites with their individual planet's bulk core. Image courtesy of http://www .daviddarling.info/encyclopedia/W/Widmanstatten_pattern.html. 
mechanism of heating to form the chondrules (they are igneous objects; Fig. 2), the mechanism of heating to differentiate planetesimals several million years later than chondrule formation is a matter of ongoing enquiry. Even if we don't know how, we do know when and where (in some cases) these events happened. The currently flying NASA DAWN mission to asteroids Vesta and Ceres has produced preliminary news bulletins consistent with the identification of Vesta with the HED planet.

The eucrites are the largest class of differentiated achondrite meteorite, but they are not unique. The brachinites, winonaites, aubrites, ureilites, and other minor classes have related stories of early differentiation to tell. The octahedrite iron meteorites tell a remarkable story of geochemical differentiation by cooling and crystallization (Wasson et al., 1980; Cook et al., 2004) that may be a model for the evolution of our own core. We delay presentation of the shergottite, chassignite, and nakhlite meteorites for the section on Mars, from which planet we think they originate.

\section{APOLLO AND LUNA LUNAR SAMPLES}

The Earth's moon was visited and sampled for petrologic study in 6 manned missions from 1969 to 1972 by the NASA Apollo program. Two robotic sample return missions from the same era mounted by the Russian space program produced Luna samples. Collectively these sample returns and their study and the orbital information on gravity and remotely-determined chemistry retrieved by these missions gave us a new appreciation of the meaning of the lunar surface and its rock types. The moon was not an archive of cosmic debris, barely dented with a few mechanical disruptions of late meteorite cratering as thought by Urey. Nor was it an active planet like the Earth with a continuing process of surface renewal. What emerged was a picture more like the eucrite planet than like the Earth. The moon completely differentiated itself early, perhaps through a magma ocean stage, and then it became quiescent without much surface modification except for the odd meteorite impact after $2 \mathrm{Ga}$ of initial evolution.

Figure 4. Lunar highlands feldspathic rock 14310 with basaltic texture from the Fra Mauro Hills landing site of Apollo 14 mission. Although this plagioclase-rich rock is likely to have been processed through a cycle of impact melting (James, 1973), statistical study of rock and soil compositions from the lunar highlands indicates that basaltic rocks of about this composition are the low-pressure melts of plagioclasebearing peridotite and to be more representative of the lunar highlands crust than is anorthosite. Note orthopyroxene core to a composite pyroxene that zones to pigeonite in its rim. Modal and early-crystallizing orthopyroxene is characteristic of this suite of old lunar highlands rocks, of eucrite achondrite meteorites, and of the magmas that feed large layered intrusions like the Bushveld and Stillwater intrusions on Earth. This early-crystallizing orthopyroxene is uncharacteristic of the most voluminous current MORB volcanism on Earth, of later mare basalts on the moon, or of shergottites, nakhlites, and chassignites (SNCs) from Mars. Pressure of melt generation and alkali budgets in the source regions are responsible for this difference between types of basalt crystallization sequences. Crossed nicols photomicrograph. Long dimension of the dark orthopyroxene core is $\sim 2.5 \mathrm{~mm}$.
This is in contrast to Earth's continuing evolution through vigorous igneous reprocessing from within, well into the present era. Thus it is clear that all terrestrial planets do not share the same evolutionary history even when they are at comparable distances from the sun, and that some other determinant like planetary size is more important for evolution.

The moon presents to the solar system surfaces of disparate topography and ages. The rough high-standing, high-albedo terranes, the highlands, have higher crater counts and are therefore older than the younger smooth, low-standing, low-albedo subcircular basins, the maria (Latin for oceans, although they contain no liquid water). The distribution of these terranes is hemispherically asymmetric. The maria are predominantly on the side of the moon permanently facing Earth through tidal locking. The basins' low albedo is a consequence of their being filled by ferrous and titaniferous basaltic lava flows which are gravitationally uncompensated, representing "mascons" or excess mass concentrations in the gravity field. These flows occupy the low points in topography excavated by multi-ring impact basins whose formation at $~ 3.9-4 \mathrm{Ga}$ ago was a benchmark event in solar system history - the late heavy bombardment. Although there was some population of mare-like basalts before the formation of the multiringed basins, most older lunar volcanism found in the highlands (Fig. 4) is more plagioclase-rich and therefore of higher albedo.

The first lunar rocks and soils returned by Apollo 11 from Tranquility base of were predominantly titaniferous basalt

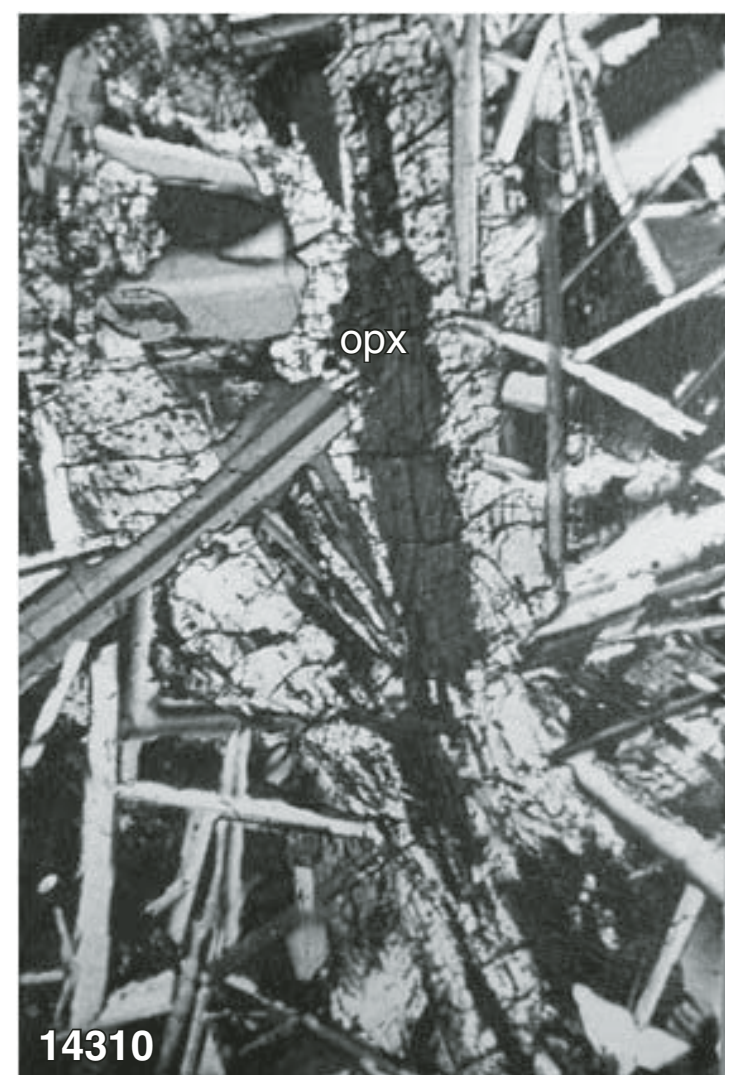


(LSAPT, 1970) dating to shortly after the late heavy bombardment. The holes were excavated and quickly filled with internally generated basaltic volcanism. The basalt characteristics were consistent with generation by internal partial melting of highly differentiated ferromagnesian materials bearing ilmenite (Walker et al., 1975), quite unlike the eucrite source regions, which could be minimally reprocessed chondrite (Stolper, 1977: Consolmagno and Drake, 1977). In the coarse-fine fraction of the soils was a population of plagioclase-rich rock fragments that seemed to bear no obvious relationship to the presumed titaniferous basalt bedrock of the landing site. A bright ray of impact-ejected debris from the light-colored highlands crossed the Apollo 11 landing site leading to identification of these plagioclase-rich particles with highland materials (Wood et al. 1970; Smith et al. 1970). A synthesis of this information, most enthusiastically pursued by Wood et al. (1970), was that early lunar history was one of a nearly full planetary meltdown — a magma ocean perhaps as much as several hundred $\mathrm{km}$ deep. Cooling and solidification of this ocean led to crystal separation by density; plagioclase flotation formed a surface layer of anorthosite, and olivine, pyroxene, and Fe-Ti-Cr oxide sank to form a complementary cumulate sequence sequestered at depth. Excavation of the multi-ringed basins in the plagioclase-rich flotation crust provided topographic collection points for eruptions of basalt generated by the subsequent partial melting of the differentiated, sometimes titaniferous, ferromagnesian cumulates (Fig. 5). This visionary synthesis explained much that was known about lunar geology and geochemistry at the time. The highlands-maria dichotomy was explained. The differentiated nature of the basalt source region was explained. Indeed the curious Eu depletions in mare basalts, and their inferred source regions, relative to the other rare earth elements, was a natural consequence of the Eu enrichments seen in the plagioclase particles from the highlands (Philpotts and Schnetzler, 1970). They were complementary reservoirs from sinking and flotation during magma ocean crystallization at low $\mathrm{pO}_{2}$ when $\mathrm{Eu}$ is predominantly $\mathrm{Eu}^{+2}$ and can enter plagioclase as a $\mathrm{Ca}$ proxy. Thus it was somewhat disappointing that Apollo 14-17 missions that directly sampled the light-colored highlands returned so little anorthosite, the presumed major ingredient of the highlands. Indeed, careful consideration of particle populations in returned samples from the highlands and of orbital XRF and $\gamma$-ray chemistry surveys suggests the highlands are much more like highAl basalt or plagioclase-rich norite than they are like anorthosite (Haskin et al., 1974). There is also a very complex array of additional rock types recognized among the highlands suites that have no simple connection to a global magma ocean's crystallization. Nevertheless the vision of a magma ocean style of lunar global differentiation has informed and motivated the past 40 years of Apollo sample research. The alternate view is that the highlands are largely comprised of a time series of internally generated, plagioclase-rich basaltic magmas, rather than a primordial global flotation crust of pure plagioclase (Walker, 1973; 1983). The highlands are a replay of the eucrite planet with, again, $\sim 10 \%$ of the planet winding up as aluminous basaltic crust, with a wrinkle that includes a later chapter of the petrological story containing exotic titaniferous internal volcanism from highly differentiated sources. Any anorthosites found in the highlands, as they are in modest percentages, can be internal differentiation products of non-global, non-primordial layered intrusions of a variety of ages and petrogeneses. Indeed the eucrite planet also seems to show some measure of plagioclase-rich and pyroxene-rich accumulates among the variants sampled. This view gets around some of the very awkward artifacts of mineral chemistry and nonprimordial sample age that are difficult to explain with a single magma ocean. This awkwardness was recently reemphasized by Borg et al. (2011). However, even if most of the rocks of the highlands are not direct flotation-crystallization products of a magma ocean, a magma ocean still could have existed. Indeed it remains a viable explanation for the differentiated character of the mare basalts' source regions, even if not for the individual rocks found in the highlands.

Whatever the merits of the magma ocean scenario, the petrology of Apollo samples clearly points to an initial differentiation
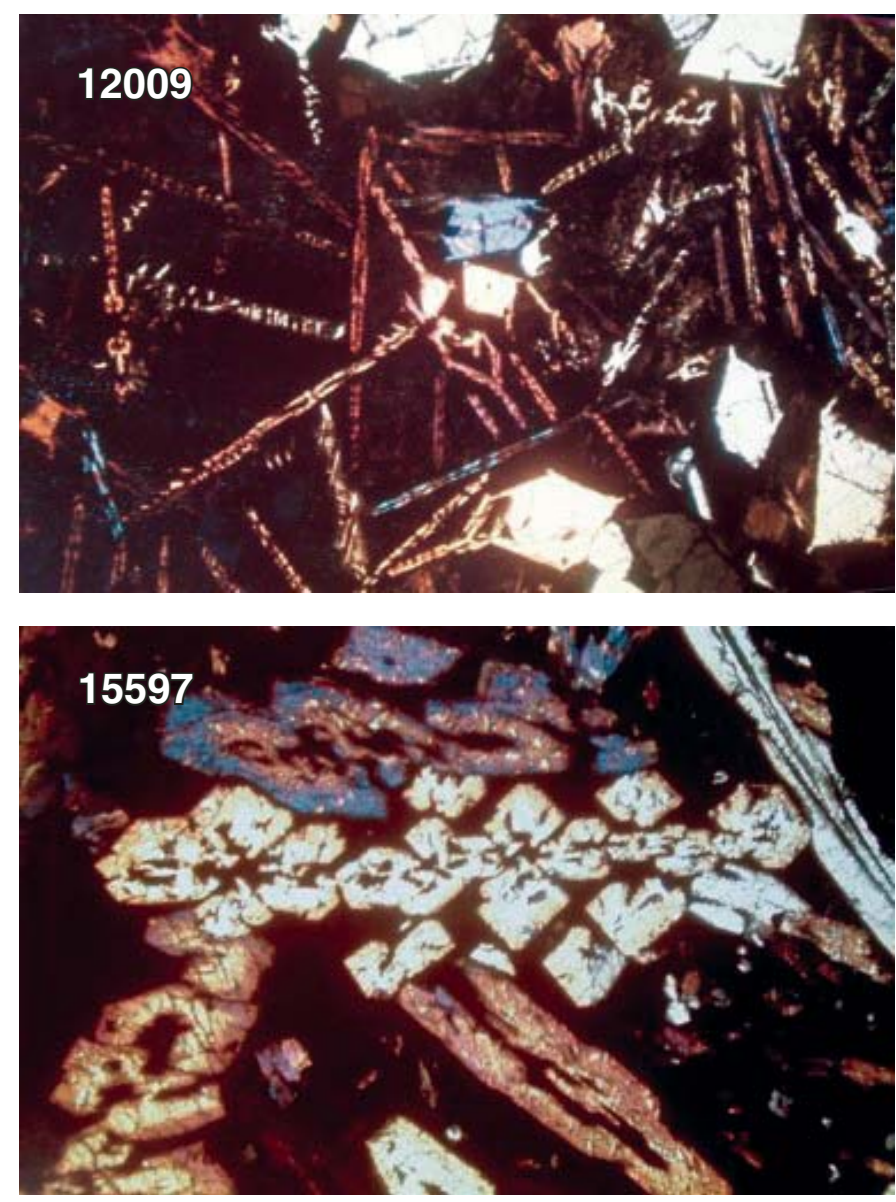

Figure 5. Lunar mare basalts. 12009 is an olivine-phyric picrite from the Ocean of Storms landing site of Apollo 12. 15597 is a zoned clinopyroxene vitrophyre from the Hadley Rille landing site of Apollo15. Photomicrographs of thin sections taken under crossed nicols illumination. Vertical dimension of each image $\sim 3 \mathrm{~mm}$. 
of profoundly igneous character rather like that experienced by the eucrite planet, and within the same time frame. That the record of these events is preserved at all is an indication that the initial differentiation was most of the story, with the Moon being slightly more persistent for a couple Ga than was the eucrite planet at generating small amounts of internal volcanism. This persistence may be related to the larger size of the Moon (Walker et al., 1979a). No extensive ongoing activity is recorded in either parent planet.

\section{SNCS AND MARS}

Mars' Tharsis ridge supports the largest volcano in the solar system: Olympus Mons. Orbital observations and robotic landings have provided ample evidence of the importance of basaltic volcanism in shaping the northern hemisphere of the planet. From crater chronology the northern basaltic plains and ridges may still be under construction even if their construction began a few Ga ago. The southern hemisphere by contrast presents heavily cratered and presumably ancient terrane dating to the time of the lunar highlands and the late heavy bombardment. Martian erosion, weathering, and volcanic resurfacing are insufficient to efface obvious signs of its ancient history even though extensive resurfacing is in slow progress.

A series of differentiated achondrite meteorites, shergottites, nakhlites, and chassignites (the SNCs), resemble partial cumulates from basaltic magma. These meteorites have crystallization ages less than $2 \mathrm{Ga}$ (Nyquist et al., 1979). They are clearly different from, and differently sourced from, the most populous class of ancient basaltic achondrites, the eucrites. From where do the SNCs come? Mars was proposed by Walker et al. (1979a) and Nyquist et al. (1979) for different reasons that were not taken very seriously at the time, because there was doubt that materials from the Moon, Mars, or any large terrestrial object, could be removed from their parent body without being destroyed. This objection was reinforced by the non-recognition of lunar samples in our meteorite collections (but it overlooked the shock damage to SNCs that is one of their distinguishing characteristics). If meteorites could not be excavated and survive as recognizable objects from a small, near body like the Moon (either eruptively, or ballistically through meteorite impact) and delivered to Earth, how could they be excavated from a still larger body without destruction and be delivered to Earth from much farther away? The objections to sourcing SNCs from Mars evaporated suddenly in 1983 with two discoveries. Lunar meteorites were indeed recognized by Marvin (1983) in the Antarctic meteorite collections being amassed! At the same time one of the Antarctic meteorites, ALHA84001, to all appearances a shergottite, was found to have an isotopic composition of gas bubbles trapped in its carapace of glass which matched that found by the Viking explorer in the Martian atmosphere (Bogard et al., 1984; Becker and Pepin 1984). SNCs are now widely accepted to be from Mars and therefore to provide samples for petrological study of Mars (McSween, 1994). The most populous group of SNCs, the sher- gottites, are generally coarse-grained igneous rocks with proportions and textures of clinopyroxene that suggests that they are partial accumulation products into liquids that were crystallizing clinopyroxene, plagioclase, and olivine. In most cases, the plagioclase is optically isotropic, indicating shock conversion to glass. Other indications of shock damage such as brecciation and planar deformation features are common. The indications from orbital and robotic lander observations of the importance of basic volcanism in covering large parts of Mars' surface were confirmed by the recognition that basalt-derived SNC meteorites were from Mars.

Stolper and McSween (1979) and Stolper et al. (1979) have provided a synthesis of SNC petrogenesis based on experimental study of the melting relations of a few of them and the application of some general geochemical considerations. The SNC's compositions are clearly not intimately related to low pressure liquid points of multiple crystal saturation (plagioclase, olivine, orthopyroxene) that both eucrites and lunar highlands basalts proved to be. They are more plausibly the product of modest pressures of partial melting from an olivine-pyroxene-rich source, implying some minimum size to the parent planet. It is possible to draw conclusions about the nature of the source regions for the liquids that could have given rise to the liquids from which, for example, the shergottites were accumulated. In contrast to the source regions for eucrites and for lunar basalts, SNC source regions are richer in alkali and other volatile components and clinopyroxene is more important than orthopyroxene. The source region has been thoroughly differentiated and retains little primitive character and seems to be metasomatized to some extent to explain its specific peculiarities compared to the more primitive source of the eucrites. The source regions also have been operating later in solar system history than either the eucrite planet or the moon in producing copious eruptive products. These characteristics fit in the planet-size-as-a-determinantof-the-complexity-and-duration-of-igneous-activity scale at the place appropriate for a parent planet the size of Mars (Walker et al., 1979a). It would be desirable for future missions to sample the southern highlands of Mars to either confirm or refute the proposition that they preserve the early differentiates of Mars. If they are not analogous to lunar highlands crust, then it would be highly instructive to learn what they are.

\section{EARTH, AND PLATE TECTONICS}

From the examples of early planetary differentiation and ongoing planetary evolution provided by the eucrites, the Apollo samples, and the SNCs, it would indeed be anomalous if basaltic volcanism were not an important agent of geochemical differentiation for the Earth (Basaltic Volcanism Study Project, 1981). It is a principal agent, but it is by no means the only agent of planetary differentiation on Earth. The crust of the ocean basins, roughly $2 / 3$ of the planet's surface area, is floored by basaltic volcanism of several sorts which we treat in detail below: mid-ocean-ridge basalts, ocean island basalts, and ocean plateau basalts. However 
the continental crust, a much-processed material compared to the previous planetary examples, is not basaltic and requires considerable ingenuity and persistence to understand its petrogenetic processes and its growth in time. The mechanics of spreading ridges, trenches, and subduction zones are key aspects of the plate tectonic revolution of the past 50 years that make possible the understanding in outline of how planetary differentiation works at present and has worked for some portion of the Earth's past (Wyllie, 1973). It is not clear that the Earth has always worked in this way, but unlike the previous planetary examples surveyed, the initial differentiation and continuing early operation of Earth's evolution is poorly recorded because so much has been overwritten by the ongoing activity.

The escape of heat from Earth's interior drives the convective overturn of the interior. Temperature excesses create buoyant forces that promote convective movements so as to relieve temperature imbalances. Sinking of cool material from the surface and the rise of hot materials from depth are partly organized around the architecture of the semi-rigid tectonic plates capping the Earth's surface which derive their lateral motions from the vertical buoyant flows. It is thought that the sinking flows associated with convergent plate margins are more effective at moving the plates than the rising flows associated with divergent plate margins or with interplate plume flow (Davies and Richards, 1992). Nevertheless the passive upwelling curtain flows beneath divergent plate margins are responsible for generation of the most important flux of magma on the present Earth. This flux erupts as largely submarine mid-ocean-ridge basalt (MORB). The melting mechanism producing the MORB flux has been known in outline since Verhoogen $(1954,1973)$ elucidated decompression melting. The mechanism arises from the difference in P-T trajectory between the adiabatic decompression experienced by a parcel of warm, buoyant material rising from depth and the slope of a melting curve for the same material. For silicates of low thermal expansion, rock rising from depth too rapidly to exchange heat with the surroundings lowers its adiabatic temperature with decompression only slightly, on the order of $0.5{ }^{\circ} \mathrm{C} / \mathrm{km}$. This temperature drop is 3-6 times less than the decrease of the melting curves with falling pressure, so that a material starting off solid and compressed may in the process of decompressing begin to melt, crossing a steeper melting curve even as its temperature falls. Its temperature falls both because the adiabatic temperature falls with decompression and because the melting process requires energy and uses a further temperature fall to turn sensible heat of the solids into the latent heat of melting. The process has been analyzed in detail by McKenzie and Bickle (1988) with the compositional dimensions most thoroughly explored by Klein and Langmuir (1987) and Langmuir et al. (1992). The phase relations for MORB system melting have been fully explored by Kinzler and Grove (1992a, 1992b).

Early investigations of MORB emphasized their tholeiitic character, their lack of wide compositional dispersion, and their obviously low pressure partial crystallization (Fig. 6) (Muir et al. 1964; Engel and Engel, 1964; Engel et al., 1965; Miyashiro et al.,
1969). Their emergence as a possible major rock type was in the context of the debate early in the time of our review period about so-called primary magmas. The concept of primary magmas arises in the context of the search for understanding the diversity of igneous rock types which are found in space and time. To Bowen (1928), using fractional crystallization to generate igneous lineages through cooling, a primary magma was one of sufficient abundance and wide enough distribution to plausibly give rise to a wider spectrum of derivative types. As his mechanism for diversifying eruptive products involved cooling, the primary material has to be supplied hotter than the derivatives. To the basalt mavens of the 1960 and 1970s (Yoder and Tilley, 1962; Cohen et al., 1967; DH Green and Ringwood, 1967a; O'Hara 1968a, 1968b; Presnall et al., 1979), the issues were a bit more complex. High eruption temperature and widespread abundance were no longer the only determinants of candidacy for primary status. The compositional details of the many variants of the types presented also had to be accommodated. The experimental details of which phases' crystallization and in which order

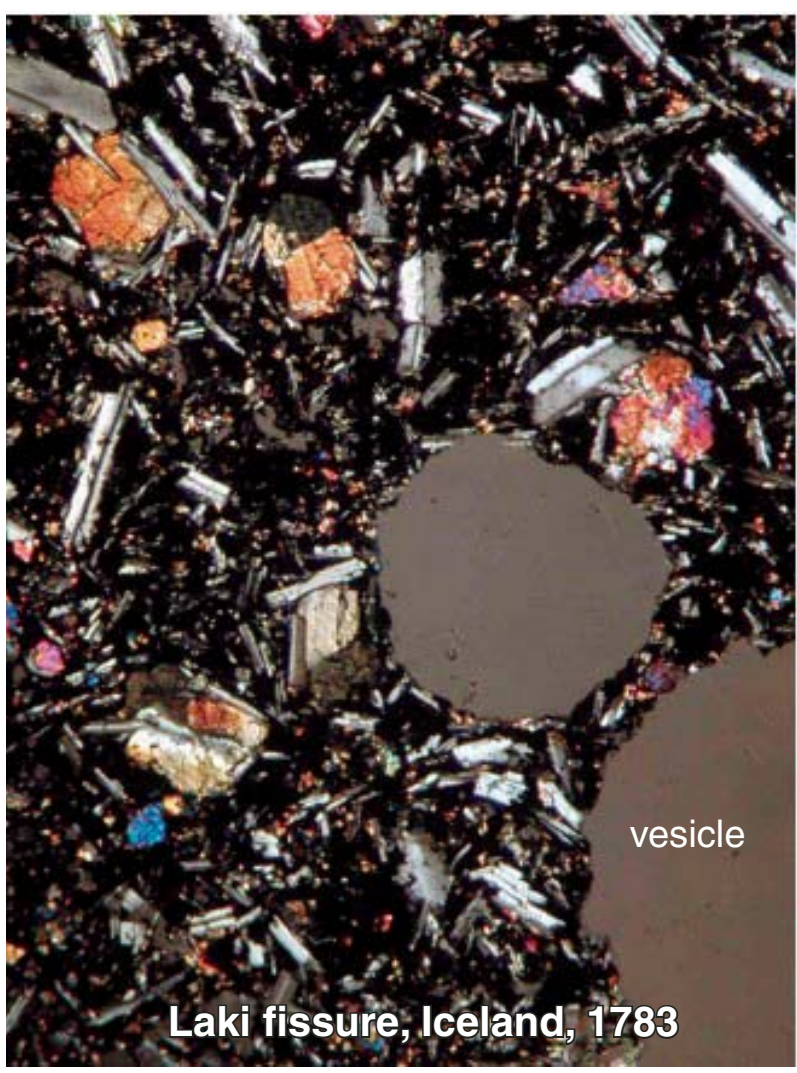

Figure 6. Photomicrograph in crossed nicols of vesicular tholeiitic basalt erupted from the Laki fissure, Iceland, in 1783. Plagioclase, olivine, and augite microphenocrysts are all present, whereas orthopyroxene is not. Aerosols and gas from this eruption had a considerable impact on the climate of the northern hemisphere, producing a virtually summerless year. Fortunately, most MORB tholeiites discharge under water. Horizontal dimension of the image is $5 \mathrm{~mm}$. 
had to be compatible collectively between the petrography, the chemistry, and the experimental demonstration of what would crystallize as temperature changes. If there were a lack of correspondence, then this could either be a show-stopper for a certain hypothesis or an illuminating idiosyncrasy offering penetrating insight. (It was often unclear which!) And this era was also one where pressure of crystallization to upper mantle depths became an experimentally accessible variable for study and incorporation into petrogenetic schemes (Boyd and England, 1960). So a primary magma also had to satisfy both high pressure generation constraints and low pressure crystallization observables. The studies of the 1960 and 1970s made much of the pressure variable as a guide for understanding basalt diversity and lineage. Thus the focus of those studies cited above was largely toward understanding the character of the melt produced at high pressure at depth which would then primarily be parental to the derivatives produced along an ascending cooling path to ultimately erupt or intrude within the geologically accessible crust.

The widespread occurrence and potential volumetric importance of MORB made them natural candidates for primary magmas in the old sense. Unfortunately there is little evidence accumulated that this voluminous rock type has produced much of a submarine lineage of descendent rock types, unlike the experience of dissecting central volcanoes on land (e.g., Carmichael, 1964). The lack of extensive dispersion of compositions characterizes MORB activity. The eventual recognition and dissection of ophiolite crustal sections as the solidified remnants of sub-ridge MORB plumbing systems have turned up little besides a small amount of plagiogranite and ilmenite gabbro differentiates among the sheeted dikes and isotropic gabbros. (Cann, 1970; Greenbaum, 1972; Coleman, 1977) Thus they fail as primary magmas in the old sense because they have neither given rise to lineages, nor do their variations take place under high temperature, high pressure fractionation conditions (O'Hara, 1968b). This is not to say that there is no compositional diversity among MORBs. And in fact there might have been more diversity if MORBs were not erupted through recharging magma chambers where extreme compositions tend to be blended away (Dungan and Rhodes, 1978; Walker et al., 1979b). This insight, following from that of O'Hara (1977), has been recently rediscovered by O'Neill and Jenner (2012). MORB clearly do show the petrographic imprint of low pressure partial crystallization, and their variations are quite understandable within the constraints of known low pressure, relatively low temperature phase relations (O'Hara, 1968b; Walker et al., 1979b; Tormey et al., 1987). And of course there is the plethora of MORB types distinguished on their trace element signatures (N-MORB, E-MORB, T-MORB, etc.).

Subsequent efforts to understand MORB variability and petrogenesis have been designed to filter out the variability introduced by the thermal adventures experienced by MORB parents after they separated from their source regions (Klein and Langmuir, 1987). The goal is to understand the source regions and generation mechanisms rather than the derivative types to which MORBs may have given rise-which are few. The physics and chemistry of the melting process are used to understand cumulative crustal thicknesses achieved, the melt fractions extracted, and the temperatures and pressures of melting. The synthesis of Langmuir et al. (1992) has been extremely successful in these objectives without dwelling on any possibility of MORBderivative magma types. The most important determinant of MORB variability is the background temperature of the mantle parcels rising beneath the ridge. Hotter materials melt to a larger extent, from greater depths, and produce thicker crusts. There are local variations introduced by variations in the constitution of the parcels. The view of Langmuir et al. (1992) that variations in mantle temperature are fundamental has been critically rejected by Niu and O'Hara (2008) who favor the perspective that the crustal thickness variations more directly reflect differences in parcel constitution. But in either rendition, the formation of MORB ocean crust seems to be an activity under which a line is drawn as an end in itself, except of course for the hydration, carbonation, weathering, and draping with sediment, with seamounts, and oceanic plateau volcanism in the inexorable trip toward consumption in convergent margins by subduction. Because there is such a large volume of ocean crust, the process of its formation is one of the most important expressions we have of ongoing planetary differentiation. We understand this formation process to be decompression partial melting of a small range of olivine-rich materials in the upper mantle, with or without recycled materials from older cycles of melting.

The voluminous steady output of MORB volcanism at divergent plate boundaries is supplemented at special times and places by episodic eruptions of rather stupendous volumes: the large igneous provinces (LIPs). Many of these LIPs in the Phanerozoic occur in ocean basins, e.g., Ontong-Java plateau, Kerguelen plateau, North Atlantic province. Provinces older than the Jurassic, e.g., Siberian and Parana traps, are restricted to continents by the absence of ocean basins old enough to hold them. That there were pre-Jurassic ocean basins is not in doubt, suggesting there may have been pre-Jurassic oceanic large igneous provinces that have been subducted without trace. There are both pre- and postJurassic large igneous provinces on continents, e.g., Columbia River, Karoo, and Keewenawan flood basalts, suggesting that these are erupted without regard to the placement of continents and oceans. Some such provinces may be involved in continental breakup. It is hard to be definite about the eruption rates of the oceanic plateaus because they are so poorly sampled or so fragmentary when just their edges are preserved on continents if they are involved in continental breakup. However, gross limits on plateau volumes and crude eruption window timescales suggest local effusion rates for million-year-scale bursts which rival the entire MORB flux. They typically have an abrupt start, large initial volumes, and a persistent trail of less voluminous eruptions after the first few million years confined to a geometric spatial track. These features are consistent with the arrival at the Earth's surface of a large plume head experiencing extensive decompression melting, followed by a tail of subsequent material following the track of the plume through the mantle. (See Campbell et al. 
[1989] for the Archean version in which the plume head is thermally diluted by entrained material, whereas the thermal intensity of the tail survives: heads it's basalt, tails it's komatiite.) The motion of the overlying lithosphere spreads the effusions from the head and tail of the plume spatially along the lithospheric motion like an overhead conveyor belt with respect to more static mantle sources beneath. This version of the tectonic cause of LIPs follows the suggestion of Morgan (1971) that one convective mode of Earth in addition to the convective motion of the plates, is the rise of deep plumes that support volcanic eruption. The coupling of the two modes leads as a natural consequence to such phenomena as age-progressive linear chains of oceanic volcanic islands.

Plumes have a wide and ingrained acceptance in the community based in part on the astonishing geometric regularity of the festoons of oceanic islands in the Pacific along flow lines away from the East Pacific Rise spreading center. But there is by no means universal acceptance of plumes. Objections to plumes have been consistently raised by Anderson (succinctly summarized most recently in 2012). Foulger (2010) has stated that there is a controversy over their existence. The arguments marshaled against plumes are based on mechanical objections and on the shabbiness of supporting evidence where it might be expected to be good, for instance in the seismic detection of deep plumesupporting thermal structure. Presnall and Gudfinnsson (2011) have examined the major element character of supposed plumederived oceanic volcanism and find no compelling case that, for instance, Hawaiian lavas are particularly hot or derived from particularly hot or deep precursors. They present a model in which various Hawaiian lavas can all be generated in various parts of the low velocity zone without plumes. The model also treats the high abundances of the compatible trace element $\mathrm{Ni}$, which is examined elsewhere in this paper. However it is not clear that this model can be successful in accounting for the differences in incompatible trace element abundances between ocean island volcanism and MORB, their ratio differences, and their isotopic differences that appear to be a distinguishing characteristic of a lot of ocean island volcanism, as reviewed most comprehensively and recently by Hofmann (2003). MORB and ocean island volcanism really do seem to be differently sourced from materials that have been geochemically distinct from one another for a long period of time. This is quite unlike the situation that might exist in the low velocity zone within the upper mantle, different parts of which should be difficult to isolate from one another in the presence of a partial melt. The proof or disproof of plumes will probably not follow from petrology, nor will mechanical objections prove insurmountable in the face of other compelling evidence for plume existence, if it is forthcoming. Mechanical objections to continental drift were eventually resolved with the advent of plate tectonics. But it is worth remembering that we no longer believe so firmly in the electromagnetic ether as we used to do.

Additional small burdens are added to oceanic crust in its progress toward consumption at trenches. These are basaltic volcano seamounts and ocean islands. These are widespread in space and time indicating that the mantle remains close to partial fusion temperatures over wide regions for long periods in time. These volcanic constructions often form linear oceanic island chains (just mentioned above in connection with plumes) when they are not entirely submarine. Their petrological character, although basaltic, may include more alkalic variants: basanites, oceanites and the like. They are not voluminous compared to either the oceanic crust or the LIP oceanic plateaus. Their generation scheme, as for the oceanic plateau basalts, is presumed to be decompression melting of mantle peridotite. The alkali-enriched character may indicate either less depletion in the source region than for MORBs or some salting of depleted peridotite with recycled material from older cycles of crust generation (Hofmann and White, 1982). And like the LIPs, alkali basaltic volcanism has a presence on the continents as well, suggesting that the formative process is not related to the distribution of continents, oceans, or plate boundaries.

One possible mechanism that may operate is to flux the required alkali ingredients early and deep in the melting process, and to have the early melt fractions be erupted less diluted by alkali-poor later melt fractions. This mechanism can operate without regard for surface tectonic environment, originating at depth with the advent of some threshold amount of appropriate flux. Carbonate has been shown experimentally to be an especially effective agent at inducing low temperature melting at pressure and to be better than water for this purpose (Dasgupta et al., 2007b). It is also effective at introducing alkali into the early melt fractions, the extreme examples of this proposition being carbonatite lavas (Wyllie and Huang, 1975). Dasgupta et al. (2007a, 2010) and Dasgupta and Hirschmann (2010) have explored the compositional consequences of melting extent and pressure on the details of alkali enrichment in basalts generated by carbonated fusion of peridotite. Dasgupta et al. (2006), Spandler et al. (2008), and Gerbode and Dasgupta (2010) have investigated the carbonated fusion of basaltic compositions for relevance to more geochemically extreme ocean island basalt.

The importance of volatile constituents for mobilizing special subsets of oceanic mantle ingredients is that they generate especially noticeable geochemical signals. This is also true for continental alkali volcanism in stable platforms and continental rifts. One aspect of well-studied examples of continental alkali volcanism is the attention they attract, which is out of proportion to their volumes. They are the locus of unusual minerals, unusual mineral chemistries, and sometimes economic resources. Thus they tend to be objects of unusually intensive study for their novelty. The classic potassic rocks of the Highwood mountains in Montana (Larsen et al., 1941a, 1941b) have been restudied by Henderson et al. (2012) using electron microprobe methods and accumulated experimental studies unavailable to Larsen and his colleagues. The impact that new tools and new theoretical and experimental background can have on the levels of insight achieved is well illustrated by this study. These hydrated, alkalirich rocks also illustrate the growing difficulty in establishing determinacy when the relatively free parameters of mixed volatile 
constituents are added to layers of complexity in the parameter space of compositions and processes that determine the narrative of petrogenesis. Henderson et al. use the mineral chemistry and zoning patterns to aid in the interpretation of the complex processes responsible for the various differentiation trends present in the rocks. It is clear that full, detailed mineralogical-petrological characterization of rock suites continues to provide a geological history record that is unavailable from geochemical analysis of bulk rock or mineral separates alone. The reliance on geochemistry without petrology is a somewhat distressing contraction of the available horizons in a substantial fraction of the current literature, to which the study of Henderson et al. provides some relief.

\section{SUBDUCTION AND ARC MAGMATISM}

Once formed and decorated, oceanic crust disappears down trenches on a few hundred million year time scale. The oldest ocean basins are Jurassic, and the only surviving slivers of older ocean crust are preserved as obducted ophiolite artifacts of ancient crustal collisions. The rest of the large volume of crust disappears into the Earth's interior at subduction zones along with the lithosphere on which it sits. Projecting the present rates of oceanic crustal production and consumption, it seems that a fairly significant fraction of the Earth's upper mantle must already have been processed by the melting and segregation events that supported this crust formation since the Proterozoic. This notion accords well with the recognition that the present upper mantle is in fact depleted in fusible components compared to some more-nearly chondritic or undepleted material. But as the material that is produced by fusion to form the oceanic crust is clearly being recycled into the mantle at trenches, the return flow is evidently not faithfully reincorporated into the MORB source regions in the mantle because those source regions still appear to be depleted. Some of the returned material may well be stored in a differentiated but inaccessible state within the mantle. But a portion of it is further digested through the complex processes that occur in conjunction with subduction zones: arc magmatism, erosion, sedimentation, orogenesis, metamorphism, granitic magmatism, and ore deposition. These processes all lead eventually to building continental crust rather than to refreshing the oceanic crustal source regions in their fusible components.

The first step in the reprocessing of MORB crust at subduction zones is manifest as an arc of regularly spaced volcanoes roughly parallel to the trench and of the order of $150 \mathrm{~km}$ behind the trench in the concave direction. This is the case whether the arc is built on either oceanic or continental crust. There seems to be a critical depth $(100-150 \mathrm{~km})$ to which slabs entering the mantle at trenches need to descend beneath the volcanic arcs before a volcanic response is triggered. Early treatments supposed that partial melting of tholeiitic basalt in the slab produced a horizontal ribbon-like band of molten andesitic material (T.H. Green and Ringwood, 1968) at the critical depth. The semi-regular spacing of the pipes feeding arc volcanoes above the planar descending slab prompted Marsh and Carmichael (1974) to model the system as a fluid mechanics instability, the spacing interval then being interpretable in terms of the viscosity and thickness contrasts of the ribbon of melts produced and their mantle/slab envelope. Presumably if the crust being remelted was MORB, reconstituted to eclogite at the pressures appropriate to the 100-150-km-deep ribbons of melt, then arc volcanism should reflect a garnet + clinopyroxene source region. Objections to this view included the difficulty in understanding how such large volumes of magma could be generated from the slab and the difficulty of understanding how a cold slab could possibly reheat to partial melting temperature, even fluxed by water, by the time of penetration of only $100-150 \mathrm{~km}$ back into the mantle. In addition, Grove et al. (1982) and Grove and Baker (1984) demonstrated that there was considerable internal complexity in the andesites of northern California that indicated the predominance of crustal open system processes in the petrogenesis of these andesites. Furthermore, the potential involvement of the slab sedimentary carapace in the process leading to granite formation can add additional layers to the petrogenetic process (Huang and Wyllie, 1973, 1981; Skora and Blundy, 2010). Whatever their origins in the mantle may have been, the current state of arcs could only be used circumspectly to infer their deep origins. Alternate views of the melt generation process, that avoided volume and thermal problems, invoked critical dewatering of the slab at some depth, with the fluid generated providing a flux for inducing melting within the overlying much warmer mantle wedge (Grove and Kinzler, 1986). This view took advantage of the much larger volume of potential source material in the wedge than in the slab and made the hydrous, explosive character of arc magmatism a natural consequence of its generation mechanism. The nature of the critical dewatering reactions and whether they are sourced primarily in the hydrated MORB crust of the slab or in the overlying subducted sediment package is a matter of on-going enquiry (Grove et al., 2012). Is it clay or amphibole or mica or chlorite or some other exotic Mg silicate hydrate that controls the release of flux?

Whatever the triggering mechanism for arc volcanism behind subduction zone, the products vary widely in composition between basalt and rhyolite, with an average composition perhaps of andesite or basaltic andesite rather like average continental crust. Other characteristics, besides diversity, that distinguish arc volcanism from MORB and plume volcanism are the depletions in $\mathrm{Nb}$ and $\mathrm{Ta}$ relative to other neighboring elements in the compatibility spectrum (Xiong, et al. 2011), the modest enrichment in light rare earth elements (LREE) and alkalis rather than depletions, and the widespread modal presence of hydrous minerals biotite and/or amphibole indicating the importance of water in the petrogenesis. The various trace element signatures may reflect the sourcing of material in slab crust or sediment (Johnson and Plank, 1999), differences in the accessory mineral assemblages of the residue of melting (Klimm et al., 2008), and/ or the nature of the liquid generated in the slab release: either aqueous fluid or silicate-rich melt (Kessel et al., 2005) The explosive eruption modes from central volcanoes rather than subdued fissure eruptions of MORBs and plumes are also distinguishable. 
In mature arcs developed on continental crust, long-lived plutonic sub-volcanic systems develop and show the calc-alkaline differentiation trends. These complexes have been exposed by erosion in, for example, the case of the Mesozoic activity of the Sierras and the Peninsular ranges of the Californias. They may be in existence now beneath currently active continental arcs. The plutonic systems form composite batholiths of incremental intrusion, differentiation, and zoned evolution that persist for $10 \mathrm{~s}$ of millions of years. Substantial silicic ignimbrite eruptions result when such plutonic chambers vent.

A central issue which needs to be resolved to reach an understanding of arc volcanism is: what materials feed the system from below the Mohorovičić discontinuity (MOHO)? Arc volcanism is presumably sourced in mantle peridotite; can some mechanism produce the full range of liquids from basalt to rhyolite present in arcs directly from peridotite? Or does the wide range in composition of liquids seen in arcs arise through crust-level differentiation processes from a limited range of materials crossing the MOHO from source mantle? This debate has swung back and forth several times during the past 50 years. Early views deriving the calc-alkaline trend of arc differentiates within orogenic crust were put forward by Kennedy (1955) and Osborn (1959). Wet sediments in orogenic piles might have their water thermally disproportionate by injection of hot mafic magma. Loss of hydrogen from the system through leakage would oxidize the magma causing the crystallization of magnetite-rich spinel. Fractionation of magnetite would suppress the expected residual concentration of $\mathrm{Fe}$ in derivative liquids characteristic of the tholeiitic trend of differentiation favored by Fenner (1929). A calc-alkaline trend of alkali and silica enrichment would develop instead. The search for additional effects expected from magnetite crystallization, such as V-depletion, was not successful.

The advent of piston-cylinder experimental apparatus for exploring melting relations at modest upper mantle pressures allowed Kushiro $(1969,1972,1973)$ to demonstrate that the addition of water to peridotite made the multiply-saturated melting products more silicic than they would be dry. This scheme is different from that advocated by T.H. Green and Ringwood (1968) for the calc-alkaline series where the silica enrichment arises from melting tholeiite rather than peridotite. Water enters silicate melts to a much greater extent than it does the minerals of peridotite olivine, pyroxene, plagioclase, spinel, etc. So the melting temperature at first melting decreases through freezing point depression. To the extent that water changes the arrangement of structural units in the melt, the stabilities of individual crystals vary. As plagioclase is highly polymerized and olivine is not, the depolymerizing effect of water on the liquid structure reduces the freezing point of olivine less than that of plagioclase. As a consequence of this differential freezing point effect, olivine has its compositional field of stability expanded relative to plagioclase and pyroxene. The multiply-saturated liquids of olivine-pyroxene-plagioclase-melt assemblages are more silicic wet than dry. Through the mechanism of variable water involvement, peridotite might be made to produce a series of partial melts of variable silica enrichment like that seen in arcs. If this mechanism is not fully responsible for the range of compositions seen all the way to rhyolite, perhaps it might be influential in shifting the center of gravity of the compositional distribution from the basalt expected as the melting product of peridotite to the andesite that is observed. The source of deep water to cause damp melting of peridotite may of course be found within the plate tectonic framework of subduction of wet crust and sediments releasing their moisture into the overlying wedge. Sisson and Grove (1993) have also used the damp suppression of plagioclase stability to improve the effectiveness of achieving calc-alkaline differentiation trends in liquids, of whatever origin, that differentiate within the crust.

Continuing investigation of the eruptive stratigraphy of arcs and the dissection of plutonic complexes in batholiths brought many investigators to the conclusion that whatever was entering the plumbing system below an arc, there was a lot of internal differentiation occurring within the arc itself that had nothing to do with variations of input on the bottom of the system. Various mechanisms of assimilation of crust, fractional crystallization, continuing recharge, spatial zonation, convective and gaseous transfers, and combinations of all of these became increasingly popular mechanisms to invoke for the detailed variations in rock type observed. Assimilative fractional crystallization (AFC) received much theoretical attention (e.g., O'Hara, 1977; DePaolo, 1981). Suggestions were even raised that thermal diffusion (the Soret effect) was able to play a role in enhancing the range of magmas produced in silicic chambers (e.g., Hildreth 1979; Shaw et al., 1976). This suggestion stimulated an experimental evaluation of whether there was any Soret activity in silicate liquids (Walker et al., 1981; Walker and DeLong, 1982). Did chemical fractionation of liquid spontaneously develop in a temperature gradient? To everyone's surprise the effect per degree turned out to be quite large and competitive with the per degree magnitude of crystal fractionation. Unfortunately the effect produces compositional arrays nothing like the arrays seen in the compositional dispersion of examples like the Bishop tuff that were postulated to be Soret-derived (Lesher and Walker, 1991). The Soret effect has proven to be quite revealing about the physical chemistry of silicate liquids even as it has proven not to be a major player in magmatic petrology. Nonetheless temperature-driven isotope fractionations in chemically zoned experimental analogs of large, hydrous, zoned magma chambers have been documented by Huang et al. (2009). Although this cannot be an unalloyed Soret process because more phases than just a single fluid are involved, the role of thermal gradients can clearly be more than to just introduce a crystallization gradient to which liquids respond by mass balance. The significance and applicability of the findings of Huang et al. are not yet fully established.

Following this interest in internal differentiation mechanisms for arcs, Plank and Langmuir (1988, 1993) changed the game entirely. Instead of worrying about the range of compositions present, they concentrated on stripping away the effects of secondary fractionations and isolating the most typical primitive compositions that would have been produced in the mantle for 
each arc or segment. They surveyed these primitive compositions for the known range of arcs globally and tried to isolate the parameters in control. They found that the thickness of crust onto which an arc is built was an important determinant of the chemistry of primitive arc lavas erupted. These primitive arc lavas are largely basalt or basaltic andesite. Their range of compositions makes sense in terms of the decompression melting taking place above a subducting slab once a melting instability is introduced. If the crust overlying a slab is thick continental crust, then the depth range over which decompression and melting can occur is restricted. Parcels rising from the wedge above the descending slab will run into crustal lithosphere and stop rising when the base of the lithosphere is encountered. Thin crust leaves a greater depth range over which partial melting can occur. Thus thin crust arcs show symptoms of larger degrees of partial melting than thick crust arcs. In this view of arcs, the feedstock passing the $\mathrm{MOHO}$ has some variations but all within the range of basaltic to basaltic andesite magma. These subtle variations do not extend to dacite or rhyolite, which presumably arise internally within the arc plumbing system through complex mechanisms.

\section{WHAT IF IT'S NOT ALL PERIDOTITE DOWN THERE?}

The supposition that the upper mantle is peridotite in bulk is based on several lines of evidence. Seismic velocities and densities of the upper mantle are consistent with peridotite, but the match is not unique. Compositional arrays of primitive meteorites and of ultrabasic terrestrial rocks are linear with an intersection in the region of peridotites (Jagoutz et al., 1979). The linearity of each array facilitates extension of each array even though the processes governing the variation in each array may be different. The intersection is presumed to be the part of the meteorite array that is the starting point for mantle processes, i.e., the mantle bulk composition. The intersection of the two arrays, meteorite and mantle, is higher than chondritic in $\mathrm{Mg} / \mathrm{Si}$ so that the implication is that primitive mantle is richer in olivine than any chondrite would be. The possible reasons for this enrichment will be examined separately below. The xenoliths disgorged from alkalic volcanic rocks like basanites and kimberlites have a population of peridotites that include garnet-bearing assemblages that record a pressure of recrystallization within the upper mantleclearly different from recognizable crustal xenoliths recording crustal pressures. Ophiolite sections complete enough to preserve the $\mathrm{MOHO}$ and the underlying harzburgite, often have large associated sections of olivine-orthopyroxene-clinopyroxeneplagioclase peridotite. As these sections occur as obducted slivers within orogenic belts, they are known as alpine peridotites. The lithologies seen overlap with some of the populations seen in xenoliths suites from alkalic volcanic rocks. And finally, phase equilibrium constraints indicate that the partial melting of such 4-phase peridotite would be expected to produce basaltic volcanism which is indeed the most voluminous melting product coming from the mantle. This suggests that 4 -phase peridotite is the most abundant feedstock. But it is by no means the only one, nor is the deep xenolith suite restricted to just peridotite. Eclogites, harzburgites, pyroxenites, and a variety of very high pressure assemblages that could be recycled subducted sedimentary crustal lithologies are also found. Likewise alpine peridotites often show varied lithologies like veins of dunite and pyroxenite within peridotite or serpentinized peridotite.

The variation of lithologies shown by xenoliths suites and alpine peridotites may become important out of proportion to their small abundance. If some of the variant lithologies are more fusible, then they will be disproportionately represented in the initial fusion products that may show characteristics that are inappropriate for 4-phase peridotite. Much attention has been given to pyroxenite lithologies in this regard. If pyroxenite has a lower $\mathrm{Mg} / \mathrm{Fe}$ than fertile peridotite because it is a reprocessed melting product of peridotite, then it may melt more readily than peridotite. Low modal olivine abundance may lead to early olivine exhaustion and therefore to elevated trace element signatures of elements like Ni that are especially compatible in olivine. Sobolev et al. $(2005,2007)$ have pointed to the very high $\mathrm{Ni}$ abundances in some Hawaiian plume basalts as evidence for the importance of recycled pyroxenite components in the ascending plume that is melting under Hawaii. The incorporation of recycled subducted oceanic crust into the source regions of plume basalts has been postulated previously on the basis of isotope and trace element signatures appropriate for altered oceanic crust (Hofmann and White, 1982). Thus the recycling of crustal lithologies back into the mantle may be a selective way of introducing special contaminants. These may be virtually invisible in the large extents of melting generally experienced at mid-ocean ridges. They become visible in special situations of lesser extents of melting, or in circumstances where the contaminants are more abundant such as in the plume incubator that is the subducted slab graveyard at the core-mantle boundary. It is possible also that they could be important and visible in arc volcanism where low degree flux melting of the wedge overlying the subducting slab operates. Straub et al. (2011) have suggested from examination of a variety of lavas, especially from the Mexican volcanic belt on thick continental crust, where high-Ni andesites are found, that the skewing of the melting of peroditite from basalt to andesite arises through the hybridization within the mantle of basaltic magma with the silicic melting products of the slab that locally generate olivine-free lithologies by reaction with the mantle. Their recognition of primitive $\mathrm{He}$ in the inclusions within high-Ni olivines suggests that the hybridization occurs in the mantle rather than being a straightforward consequence of contamination by the thick continental crust.

\section{GRANITES AND STILL MORE GRANITES}

A natural end member of terrestrial magmatic rock types is those that are most silica-rich: granite if plutonic and rhyolite if extrusive. Bowen (1928) also interpreted them as a lowtemperature end-member of a differentiation sequence from basalt through the operation of fractional crystallization. Bowen's 
views were not universally shared (Read, 1957) although most granites are now viewed as igneous rocks whether or not they are the products of fractional crystallization of basalt. A diversity of granite mineralogical types, settings, and trace element signatures is now recognized that point to several different parentages. That granites occupy the low melting points in their composition space (Tuttle and Bowen, 1958), the feature of such importance to Bowen, is a common thread in their genesis either by partial melting or crystallization or by some more complicated process. The great zoned batholithic/ignimbrite complexes of continental arcs already referred to in conjunction with the building of continental crust from arcs are the locus of extensive granite petrogenesis. The volumetric importance, endurance, diversity of rock types, and complexity of these systems set them apart from other modes of granite production. The fact that arc magmatism on oceanic plates does not generate such large amounts of silicic magma suggests that the continental crust itself contributes material to the construction of the batholiths and to the ignimbrite complexes that form upon continental crust. If it were simply continental crust remelting, then there remains the issue of where the heat to do the remelting came from. But there is considerable isotopic and trace element evidence that there are substantial contributions to the batholiths of material from the mantle that has not built up high ${ }^{87 / 86} \mathrm{Sr}$ and low ${ }^{143 / 144} \mathrm{Nd}$ representative of continental crust. In an arc built on continental crust, basalts and basaltic andesites from the mantle may have some tendency to pond at the MOHO or within the crust. They are denser than silicic crust. Already warm lower crust will have difficulty avoiding becoming partially melted and perhaps partly hybridized with the mantlederived magmas. Granite then can be an internal differentiation product of continental arc magmatic systems, being sourced in a combination of crustal and mantle igneous materials.

Chappell and White (1974) and White and Chappell (1983) studied the granites of the Lachlan fold belt in southeastern Australia and recognized that there were different sources of granite magmas, some of which seemed to be derived from the melting of pelitic sedimentary rocks-S-type granites-without mantle involvement. These rocks tend to be peraluminous, have cognate xenoliths of similar lithologies but enriched in mafic minerals, and have high $\mathrm{K}$ relative to $\mathrm{Na}$ and $\mathrm{Ca}$. The granites of continentcontinent collisional orogens that do not have well-developed magmatic arcs, like the Himalaya, also produce two-mica granites that appear to be the melting products of sedimentary rocks in the over-thickened crustal pile (Le Fort, 1981). This is consistent with the $\mathrm{S}$ designation for such rocks that are found in Australia where batholiths typical of continental arcs with mantle involvement are also developed. The S-type rocks are distinguished from metaluminous granites typical of continental arcs that have higher $\mathrm{Na}$ and $\mathrm{Ca}$ relative to $\mathrm{K}$ and cognate xenoliths as mafic as gabbro. The protolithic source rocks were suggested to be igneous-I-type granites more typical of batholiths. There has been considerable anxiety over these labels (Zen, 1988; Miller et al., 1990) and whether the source rocks can be confidently identified, but there do appear to be distinguishable end-members in the granite spectrum whether or not the protolithic designations are accurate in all cases.

Both I and S-type granites are found in collisional orogens. And yet there are still more granite types beyond those of collisional orogens, of perhaps diminished volumetric importance, that nevertheless indicate that granite production and occurrence is not a one or even a two-act show. The remaining grab-bag of types found outside orogens is designated A-type or anorogenic granite (Loiselle and Wones, 1979). These types collectively also tend to be more alkalic, have high $\mathrm{K} / \mathrm{Na}$, lower water fugacities, higher halogens, and higher emplacement temperatures than orogenic granites. Thus the occurrence of hypersolvus alkali feldspar perthites and anhydrous mafic minerals are more common than in orogenic granites. There is a typical association of A-type granites with tholeiitic to mildly alkaline basaltic volcanism. They often occur in lineaments, sometimes with a loose age progression e.g., the White Mountains of New Hampshire or the Cameroon line of west Africa (Eby, 1987; Fitton and Dunlop, 1985). A wide variety of mechanisms, usually invoking involvement of mafic and/or alkali magmas has been advocated for this diverse association (Eby, 1990). These mechanisms include remelting of crust into which basalt intrudes, fractionation of alkali parental magmas, and magmatism generated by rifting. It is highly probable that no one mechanism applies to all A-type granites.

\section{WHAT WAS THE CONTINENTAL GROWTH HISTORY?}

The plate tectonic cycle produces MORB crust at mid-ocean ridges and consumes it at the trenches to form arcs which become incorporated into continents (Condie, 1989). Those arcs become processed and reprocessed in time to show more-potassic granite at the surface. Parts of continents, the cratons, have been stable at the Earth's surface since the Proterozoic or earlier. And some parts of continents suffer partial subduction through collision and/or erosion by subduction. One of the headline discoveries of the past 20 years is that deep subduction with subsequent rebound of some of the subducted materials (including continental protoliths) to the surface can be recognized in ultra-highpressure metamorphic belts. Therefore it is worth asking whether the continental mass is in steady state, is growing, or is eroding. Part of the answer to these questions depends on the rates and even on the existence of plate tectonic operation in the distant past (Sleep, 2000). That tectonics has much to do with continental growth is a new insight highlighted by Bickford (1988) in his Geological Society of America centennial review. To the extent that plate tectonics is a reflection of lateral motions in the crust attending heat elimination from the Earth's interior, there is some expectation that the tectonic rates and their crust-building consequences might scale in some way with the heat production that occurs within the Earth. The heat budget from radioactive decay has declined through time in a predictable way, suggesting that crustal production rates in the past could have been faster. Additional parts of the answer also involve an evaluation of how much 
of the continental consolidation process involves the addition of new material and how much simply reworks and further differentiates existing continental materials. Does craton formation permanently enlist material into continents, or are some cratons not forever, being subject to subduction erosion?

Harrison (2009) has reviewed the large number of continental growth models. Most models generally show a change in behavior in the early Archean. Armstrong (1981) shows the continental mass to be at steady-state since the early Archean, reflecting more or less uniform continental freeboard with respect to sea level throughout the geological record. On the other hand a rather larger group of models show monotonic growth in continental crust mass within the geological record, starting from little or no crust at the end of the Hadean. The models beginning with late Hadean crustal accumulation largely reflect the absence of a preserved Hadean crustal rock record. The models differ considerably in the age at which half the mass of the continents is in place. These growth-since-the-Archean models collectively rely on isotopic systematics and other geochemical evidence for evolution of the continental compositions (McLennan and Taylor, 1991). They also are based on inferred arc growth rates in the Phanerozoic and by scaling of heat production to crust production rates. An outlier model of Fyfe (1978) has continental crust decreasing since the Archean based on a mass balance at arcs that implies net erosion of continents. Clearly there has been a wide exploration of parameter and constraint space in a fruitless search for consensus. Progress in choosing among the alternatives can be made if time-integrated information on geochemical reservoir separations could be obtained from appropriate samples as done by, for instance, Hawkesworth and Kemp (2006), Hawkesworth et al. (2010), or Condie et al. (2011). It would also be useful to know how far back in time the plate tectonic cycle, or something like it, has been in operation. Although the radioactive heat production rates are predictable and suggest things should have been hotter in the past and perhaps mantle convection more vigorous, the consequences of this for mantle temperature and rheology are not straightforward (Korenaga, 2006). Hargraves (1976) suggested that the higher heat production in the Archean would have things warm enough to suppress subduction and hence nobble the plate tectonic cycle. However Watson and Harrison (2005) advocate that detrital Hadean zircons from the Jack Hills in Australia record crystallization temperatures near $\sim 700^{\circ} \mathrm{C}$. These are the minimum melting temperatures experienced in wet subduction conditions on the present Earth, implying that something like current oceans, subduction, and plate tectonics has existed since a time only a few hundred million years from the Earth's formation. This raises the following question.

\section{HOW DIFFERENT WAS THE EARLY EARTH?}

That the Earth might have been quite a different place from today for its first couple billion years has been suggested by at least four different lines of evidence. The first is that heat production from radioactivity, the largest component of the Earth's present heat budget, must have been at least an order of magnitude greater in the Hadean and Archean. The Earth must have responded in some way to release this heat without a complete meltdown, because we do have at least a fragmentary geological record at least back to the late heavy bombardment $\sim 4 \mathrm{Ga}$ ago. One imagines that this record would not have survived a global meltdown, an almost mathematical certainty given the ancient radioactive heat budget, unless the Earth had additional response mechanisms to those that are operating now. The second evidence for differences in the Archean comes from the recognition during the review period of a new sort of ultramafic igneous rock type with inferred eruption temperatures unprecedently high for the modern Earth. The Archean mantle may have been as much as $\sim 400{ }^{\circ} \mathrm{C}$ hotter in places than it is today, reinforcing the inferences from radioactivity budget projected for the past (Green, 1975). These rocks, komatiites (Fig. 7), were first described from the Onverwaacht of the Barberton Mountain Land of South Africa (Viljoen and Viljoen, 1969). The experimental work showing the need for high melting temperature was performed by Green et al. (1975). Komatiites of similarly high eruption temperatures have now been found in other Archean cratons (Nesbitt, 1971; Pyke et al., 1973) and in a few restricted Phanerozoic large igneous province occurrences, to perhaps as young as Cretaceous (Echeverria, 1980). There is some suggestion that the eruption temperatures decrease with time (Herzberg and Gazel, 2009). The notion that the temperatures are particularly high is disputed by Grove and Parman (2004) on the grounds that the crystallization textures shown by the rocks indicate wet crystallization and that wet subduction rather than hot, dry plumes is a more fitting production scheme for komatiites. (The high eruption temperatures inferred for komatiites are only secure for dry conditions.) Grove and Parman advocate only modest difference from today for the Archean and for the ancient operation of subduction. Arndt et al. (2008) reject the wet melting scenario.

The third line of evidence that the Archean was different comes from the tectonic style of what is found in the fragmentary record. The Google Earth view of the Pilbara block of NW Australia in (Fig. 8) shows a particularly well exposed Archean terrane. These terranes are like no others in the geological record. The broad blob-like or eliptical areas of vaguely calc-alkaline light tan gneiss and migmatite are set apart from one another by keels of darker greenstone-grade metavolcanic and metasedimentary rocks. The tan terranes of gray gneiss of tonalite, trondjhemite, and granodiorite lithologies - the TTG association-appear to dome and possibly intrude the belts of greenstone. The age relations of the TTG materials and the greenstones are confusing in outcrop and unresolved by radiometric age dating, appearing to be largely synchronous over a range of ages. Possibly the TTG domes are the tops of diapirs formed from partially melting of foundered, subducted, or overthickened greenstones. This mode of genesis is broadly consistent with the experimental work of T.H. Green and Ringwood (1968), Lambert and Wyllie (1970), Stern and Wyllie (1978), Rapp et al. (1991) and Rapp and Watson (1995) suggesting that partial melting of basaltic lithologies at modest pressure and 

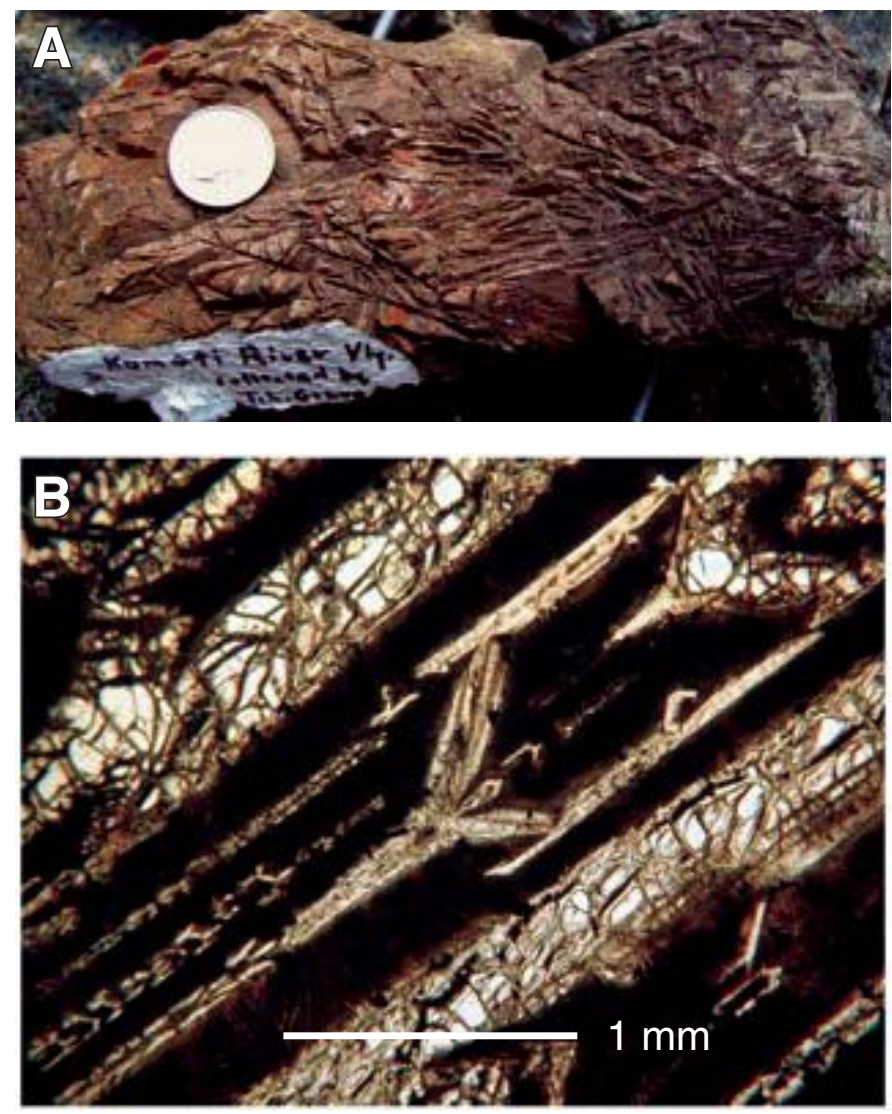

Figure 7. Komatiite: (A) hand specimen and (B) thin section. (A) Olivine plates intersecting the specimen's surface give characteristic spinifex texture. Hand specimen from Komatii River Valley, Barberton Mt. Land, S. Africa, courtesy of TL Grove. Dime for scale. (B) Thin section, plane-polarized illumination, of spinifex olivines in komatiite from Pike's Hill, Munro Twp., Ontario. water content is responsible. But we have no completely faithful modern analogs for this rock association, reinforcing the suggestion that the Earth's tectonic past was different (Hamilton, 1998; Bédard et al., 2003). The prevalence of tonalite and trondjhemite granitoid lithologies in the Archean, in contrast to the increasing abundance of K-rich granites subsequently, shows up in the compositions of sediments derived from the respective source terranes with time. The observation of increasing $\mathrm{K} / \mathrm{Na}$ in the sedimentary record is important to the McLennan and Taylor (1991) model of continental growth and again suggests that our geological past was different from the present.

The fourth line of evidence is that there appears to have been a qualitative change in Earth's surface atmospheric conditions near the Archean to Proterozoic boundary (Holland, 1984, 2002). Progressive oxygenation of the atmosphere, perhaps as a response to the rise of photosynthetic organisms, became apparent in the sedimentary rock record of the Proterozoic (Farquhar et al., 2000, 2010). The great oxygenation event has been recently been recognized as a turning point in the mineralogical evolution of our planet (Hazen et al., 2008, 2011; Hazen and Ferry, 2010). In the presence of an oxygenated atmosphere, minerals can form that were previously unstable in neutral or reducing atmospheres. Thus, bursts of new mineral species appear in the geological record. In like manner, new mineralogy develops in synchronization with the supercontinent-assembling episodes of the past. It is not a stretch to imagine that these changes could also rebound into the internal workings of our planet. The question is, how deep do such changes penetrate? Certainly shallow hydrothermal systems, including those involved in ore formation, have been involved in the change. Whether the lower crust or mantle see any of the surface effects remains to be studied. The concept of mineral evolution has yet to be fully explored, and if established,

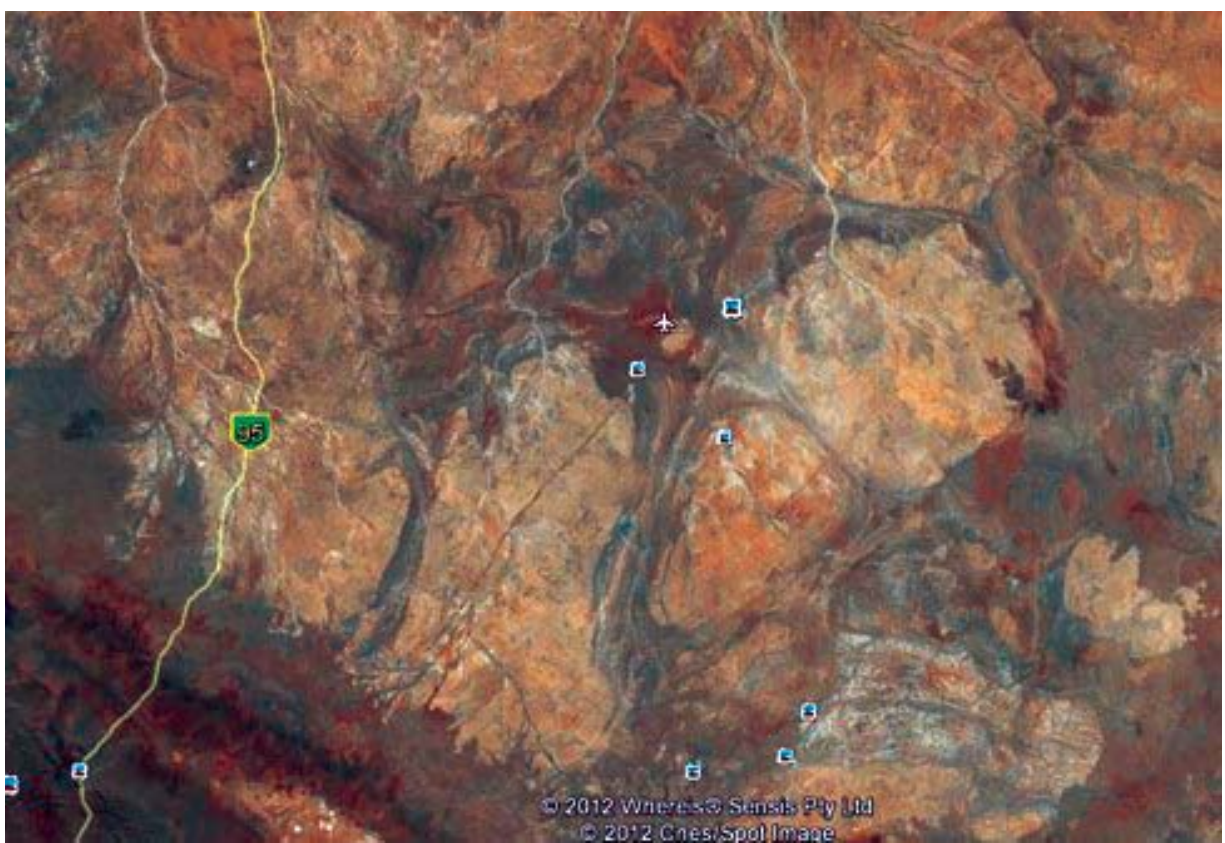

Figure 8. Google Earth view of Pilbara craton, NW Australia. Eliptical areas of tan-gray TTG gneiss surrounded and divided by plunging keels of darker greenstone belts. Marble Bar is a little north of the center of this image. This image not only illustrates the unique tectonic style of the Archean craton's TTG/greenstone association, but also illustrates how information has become so very much more accessible in the past 50 years. Any school child with an internet connection can be an explorer on a scale undreamed of 50 years ago using these new digital tools. 
would signal that the atmosphere, biosphere, hydrosphere, and lithosphere may have a more complex set of interconnections than previously imagined, except possibly by Lovelock (1995). The study of mineral evolution, its reality, and its possible symbiosis with life's evolution is just getting under way (Grew et al., 2011). Given the rather robust indications that our planet was a different place when it was young (Nisbet, 1987), the inference of Watson and Harrison (2005) that wet, cool subduction was operating within a couple 100 million years of planetary accretion, as it does today, is all the more remarkable. Unfortunately, the meager constraints we have at present are elastic enough to be accommodated by the extremes of "little crust" or a "full complement of continental crust" at the start of the Archean. It is hoped that this topic will receive the increased scrutiny it deserves in the next few decades.

\section{WHAT ARE CRATONS AND HOW DO THEY FORM?}

Archean rocks have their maximum exposure in cratonic cores of continental blocks that are tectonically coherent and apparently stable for long periods since their amalgamation. Part of their stability may be derived from their lithospheric keels (Jordan, 1988). But it is currently a matter left to resolve whether those keels provide much mechanical strength as well as the buoyancy required for stability. Their tectonic stability is in contrast to the orogenic belts which tend to be arranged between and along the margins of the cratons. Continental assembly is an exercise in collecting collisional damage zones on the margins of relatively rigid cratonic blocks. The cratons are the areas of principal exposure of the TTG/greenstone terranes. Nothing like them appears to be forming today. If the formation process is no longer active today, the uniformitarian approach is then difficult to apply in the Archean - even if the subduction process or something like plate tectonics were to have been operative then.

What processes might lead to 400-km-thick, stable, depleted lithosphere? Depleted lithosphere is buoyant compared to fertile lithosphere (Boyd, 1989), contributing to its resistance to subduction when accumulated under a continent. So the outstanding problem is to accumulate such a great thickness of lithosphere without accumulating the expected consequences of the formational depletion event in the crust-great thicknesses of effusive volcanic rock which do not appear to be present in the crustal record. One way the depletion without crustal effusion might be accomplished is to simply stack plates of oceanic lithosphere tectonically by abortive, flat subduction in a hotter Archean mantle. Each tier of the stack is depleted but the effusive complement of the depletion may be present as part of the stack or partially scraped away laterally in the subduction process. Either way, it is no longer fully visible in the crust. Aulbach (2012) has objected to this reconstruction because there is some consensus that the compositional dispersion in the cratonic, depleted mantle xenolith suite indicates melt extraction at rather higher pressures than the $<3 \mathrm{GPa}$ pressures typical of normal oceanic crust formation. This consensus is not exclusionary to the possibility that additional mechanisms of introducing compositional dispersion into xenoliths suites may be operating as reviewed below. Boyd (1989) tied the depletion to deep, hot komatiitic magmatism for the Kaapvaal xenoliths as did Bernstein et al. (1998) for east Greenland xenoliths. Such high extraction pressures $(\sim 5 \mathrm{GPa}$ and appropriately high temperatures) are more natural for plume basalts than for ridges. Plume basalts may have sufficiently hot petrogenesis to fit the xenolith constraints, but it becomes increasingly difficult to evade the expectation that there should be a lot of volcanism visible at the surface when the craton stabilizes. Aulbach (2012), favoring the plume interpretation, explains the paucity of volcanism as a consequence of it being sidetracked into plutonism and then removed by delamination. Eclogite residues from TTG production (and eclogites formed from komatiites that subcrete at some depth rather than erupt) are presumed capable of sinking through the buoyant depleted residuum. In this way the expected volcanism is transformed to eclogite which is lost to depth. It is possible to imagine related scenarios in which transformation to eclogite of the basic volcanism complementary to TTG magmatism induces wholesale foundering of significant amounts of depleted lithosphere. The complementary eclogite fraction delaminates at depth and then the now-buoyant residues from the delamination return to near the Earth's surface as depleted cratonic lithosphere harzburgites (Herzberg and Rudnick, 2012). Herzberg and Rudnick's model for Archean cratonization has parallels with the model of Hacker et al. (2011) for subsequent continental growth by relamination of deeply subducted continental materials. Buoyancy relations of subducted material make the parts which convert to eclogite vulnerable to unrestricted foundering into the mantle. This separation leaves the residual material from which the eclogite separates buoyant again. Rebound of this buoyant material, perhaps with decompression partial melting, could cause a relamination to form lower continental crust in a mode reminiscent of lithospheric keel formation during the hotter Archean. More or less metasomatism and/or refertilization of the lithosphere make recognition of the multiple processes responsible for the final state more challenging. (This is more or less the situation we previously encountered for the formation of lunar highlands crust: that it is probably a complex serial process rather than a single grand flotation product.) The serial operation of multiple processes obscures the operation of each of the processes until an appropriate set of discriminants can be found, which remains to be fully done. It is also possible that there is no single mode of craton (and/or continent) formation.

\section{WHY IS THE UPPER MANTLE OLIVINE-RICH PERIDOTITE?}

The Earth's mantle has a higher $\mathrm{Mg} / \mathrm{Si}$ than chondritic meteorites (Maaloe and Aoki, 1977: Jagoutz et al., 1979; McDonough, 2003). Deviations from chondritic when demonstrable for Earth are usually measured in ppm (Kleine et al., 2002; Boyet and Carlson, 2005), not in fractions of $1 / 2$. Removing Si through 
evaporation during accretion or early differentiation should have removed alkalies like $\mathrm{K}$ and $\mathrm{Rb}$ to a greater extent than observed. Removing Si through core formation is unlikely to account for the $\mathrm{Mg}$ excess. For core formation to have been reducing enough to sequester substantial $\mathrm{Si}$ in the core, virtually no Fe should remain oxidized in the silicate part of the Earth. But the Earth has roughly $1 \mathrm{Fe}^{+2}$ for every $9 \mathrm{Mg}$ in its silicate portion. Therefore it is more likely that there is some other fractionation mechanism that can grossly alter the $\mathrm{Mg} / \mathrm{Si}$ in various parts of the silicate Earth-which then becomes heterogeneous. The upper mantle, from which the samples come that give estimates of mantle composition, could be different from the lower mantle. If the Earth is roughly chondritic then the lower mantle would be expected to have lower $\mathrm{Mg} / \mathrm{Si}$ than the upper mantle. In modal terms, the upper mantle olivine/pyroxene is higher than expected for a chondritic Earth. This could be the result of olivine enrichment or of depletion in pyroxene-rich materials that are more fusible than olivine. Or there could be a complicated interplay between several mechanisms.

Resolutions of this discrepancy once it is recognized are to admit that the Earth is not chondritic (e.g., Campbell and O'Neill, 2012), or that Si was either lost through evaporation or core formation. Other resolutions have tended to explore mechanisms of internal differentiation for the mantle to render it heterogeneous with a more olivine-rich upper mantle. An example of one sort of resolution comes from the study of silicate liquid density as a function of pressure (Stolper et al., 1981; Rigden et al., 1988; Agee and Walker, 1988). The initial compressibility of silicate liquids that are produced by the melting of olivine-pyroxene-rich crystalline materials of the mantle is an order of magnitude larger than the compressibility of the crystals. The liquids are less dense than the crystalline feedstock at low pressure and thus volcanic liquids usually erupt through buoyancy. However the application of several GPa reverses the buoyancy relations and the more compressible liquids are no longer buoyant once some pressure threshold of 5-10 GPa (which is dependent on system compositional details) is exceeded. If Earth had an initial deep magma ocean stage, olivine flotation to the upper part of the system is a plausible consequence of the demonstrated density relations of silicate liquid and crystals at modest pressures to 10s of GPa. However, olivine accumulation might upset the chondritic Ni/Co observed in upper mantle rocks. Furthermore, it is difficult to imagine such initial differentiation stratigraphy being preserved in an Earth being stirred by vigorous solid state convection. The Earth also continues to undergo dynamic differentiating by partial melting that might also erode any initial stratigraphy.

A second sort of resolution to the conundrum of the olivinerichness of the upper mantle was provided by the newly determined melting relations of ultrabasic materials at 10 s of GPa in a new generation of solid media, multi-anvil devices (e.g., Herzberg, 1983; Ohtani, 1985; Takahashi and Scarfe, 1985). It was shown that the very broad melting interval of $\sim 500{ }^{\circ} \mathrm{C}$ shown by peridotites at low pressure collapsed to a separation of liquidus and solidus of less than $\sim 200{ }^{\circ} \mathrm{C}$ at pressures between 10 and
$20 \mathrm{GPa}$ as the liquidus crystals changed from olivines and pyroxenes to garnets and eventually perovskites at slightly higher pressures. These sorts of multiple-saturation-near-the-liquidus relations had been used previously in the study of basalt petrogenesis. Partial melting of 4-phase peridotite at cotectics of multiple saturation is a mechanism for generating parental basaltic liquids. Herzberg and O'Hara (1985) applied this reasoning to the peridotite phase relations and suggested that perhaps peridotite was a partial melt of the deep mantle where olivinepyroxene assemblages were being replaced by garnet-perovskitemagnesiowustite assemblages. Walker (1986) pointed out that the phase relations, if significant, were just as likely to indicate that the upper mantle was a crystallization residue rather than a partial melt; however the phase relations were not secure enough even in principle to strongly support either alternative.

More recent thinking about the peridotitic nature of the mantle has been focused on understanding the compositional spectrum present. Lherzolites and harzburgites typically found in oceanic regions show a systematic relation between $\mathrm{Mg \#}$ and modal olivine abundance suggestive of depletion by basaltic melt extraction. The depletion array is demonstrated by Boyd (1989) to be different in areas of cratonic lithosphere. The Mg\# is found to be systematically higher in cratons and almost invariant with modal olivine abundance. The complement to olivine in these depleted xenoliths is orthopyroxene rather than the normal mix of 2 pyroxenes and an aluminous phase. They are modally richer in orthopyroxene than expected when they are not extraolivine-rich. That they are "depleted" suggests that they might have achieved their compositions and compositional variations through the extraction of some substantial melt fraction. Boyd (1989) suggested that the coupled excesses in Mg\# and orthopyroxene could be achieved by extraction of komatiite instead of basalt. Basalt is more effective at leaving an olivine-rich residue because it extracts less olivine-rich material than does komatiite. Komatiite extraction is more effective at increasing modal orthopyroxene in the residue because it preferentially removes more olivine than basalt. In the case of the Kaapvaal craton source of many of Boyd's peridotite samples, this volcanism could have contributed to the stabilization of the craton. The olivine-richness of the specific samples involves removing melt components (basalt or komatiite) which are poorer in olivine than an already olivine-rich fertile mantle peridotite composition. The detailed nature of this depletion process has been most thoroughly explored by Walter (1998) and Walter (2003) based on new experimental study of peridotite melting at the high pressures where it would have occurred.

In contrast to Boyd's solution to the problem of peridotite variations, Kelemen et al. (1998) attribute the excesses of orthopyroxene in the high $\mathrm{Mg \#}$ harzburgites to refertilization of very badly depleted peridotite. The view of Kelemen et al. (1995) is that the depletion of peridotite by basalt extraction is not a spatially uniform process. Focused porous flow in the mantle leaves a residue of dunite in the tracks of the focused melt migration. More extensive melt extraction leaves more dunite behind as 
extreme residues of the peridotite that yielded the basalts. Bernstein et al. (2007) noted the small variation in $\mathrm{Mg} \#$ of depleted peridotite xenoliths worldwide and noted the average Mg\# corresponded to that at which orthopyroxene would be exhausted in the melting of fertile mantle. Thus extreme depletion to the extent of leaving dunite residues might be more than a spatially isolated occurrence during the extensive melting attending the formation of Archean cratons. This view is generically similar to Boyd's except there is no special modal orthopyroxene booster from komatiite extraction in Boyd's model. Kelemen et al. achieve their modal excess of orthopyroxene in the dunites ( = badly depleted peridotite) through a later secondary reaction process where silica-rich melts react with the dunite to form more orthopyroxene. The later melts responsible for this silica enrichment may be produced by partial melting of eclogites in a subduction zone/mantle wedge complex where continental growth is occurring. This is at minimum a complex two stage process, but the complexity implied does provide a mechanism for connecting continental growth with mantle depletion that offers more flexibility than simpler models. And perhaps this is part of the answer to the question of why is the upper mantle so olivine rich: there is no one answer. There undoubtedly was initial mantle stratigraphy, perhaps long erased. There were undoubtedly wholesale melting and crystallization processes. There were density relations calling for relative motions of the packages involved. Some of these melt transfers involved depleting the residual mantle and some of the melt transfers involved refertilization. "All of the above" is probably the answer with which we will have to be content for the present when pondering the processes responsible for the olivine-rich composition and compositional range of mantle peridotite.

\section{MANTLE PHASE CHANGE PETROLOGY}

That the Earth has a seismically detectable layered structure has been known in increasing detail since Oldham (1906) discovered the core. The milestone study of Birch (1952) summarized the state of knowledge about the seismic structure of the mantle and core and gave speculations on the mineralogical origins of the changes of seismic velocity with depth known at the time. A principal issue was whether the seismic velocity variations could be accommodated with uniform materials undergoing self compression and isochemical, compression-driven phase changes or whether chemical layering of material was also required. To evaluate the second possibility, a map of the possible mantle constituent phase changes must be understood. The period under review has seen an explosion of new mineral physics phase change petrology information and of seismological constraints on the phase and/or compositional changes that may be responsible for that layering. Dziewonski and Anderson (1981) and Anderson (1989) have given syntheses of the state of knowledge of these topics midway through the review period. Agee (1998) and Bina (1998) have subsequently reviewed these topics for the upper and lower mantles respectively.
The early $\mathrm{MOHO}$ controversy captures well the flavor of the interplay between mineralogy and composition as competing determinants of seismic transition structure of the silicate Earth. The MOHO is the seismic discontinuity that formally separates the crust and mantle. In the oceans its depth is at $\sim 6 \mathrm{~km}$ whereas under the continents it may be found at 30$70 \mathrm{~km}$. A phase change from basalt mineralogy of plagioclase feldspar plus augitic clinopyroxene to denser, compositionallyequivalent eclogite mineralogy of garnet plus omphacitic pyroxene has about the right jump in density and seismic velocity to be responsible for the MOHO (Lovering, 1958). But does the transition to denser eclogite mineralogy occur at a pressure that is appropriate for $6 \mathrm{~km}$ depth in the ocean basins? Or at 30$70 \mathrm{~km}$ under continents? Could it be both given appropriate shifts in basalt composition and P-T geotherms as imagined by Lovering? Is the lower continental crust basalt anyway, as presumably the ocean crust is? And is the phase transition narrow enough in pressure to be responsible for a seismically sharp reflection? These questions were approached experimentally in the 1960s with the newly available piston-cylinder technology (Boyd and England, 1960). Yoder and Tilley (1962) showed that Glenelg eclogite had fully reverted to basalt mineralogy at $10 \mathrm{kbar}$ whereas it remained garnet and clinopyroxene at $20 \mathrm{kbar}$. This clearly showed that at least this composition could not be compatible with the MOHO being the basalt to eclogite transition under the ocean basins because the seismic transition occurred at a depth that was still firmly in the gabbro-stable region. Yoder and Tilley also questioned that this transformation could be responsible for the transition under continents, even though the pressure range was roughly compatible with the seismic depth of the transition. The extent of complex solutions involved in the various minerals was expected to spread the transition over a considerable depth rather than forming a seismically sharp boundary. Considerably more detailed studies of the gabbro-eclogite transformation and its bandwidth by Cohen et al. (1967) and Green and Ringwood (1967b) showed a rather large stability field for eclogite facies in the pressure range of the continental MOHO. However the interest in interpreting the $\mathrm{MOHO}$ as this facies boundary was not revived because of concern that the bandwidth of the transition in pressure was too broad to be consistent with the sharpness of the seismic transition in depth. Attention was diverted instead into the variations of mineral chemistry for application in thermobarometry of granulite terranes. No study found a potential match for the MOHO under the oceans. Subsequent geological investigations of ophiolites have identified the MOHO as a chemical-lithological transition between gabbros and other magmatic cumulates and transposed harzburgite mantle residues from the melting process (Cann, 1970; Coleman, 1977). Thus the oceanic MOHO is a compositional transition rather than just an isochemical pressure-induced phase change.

The seismic transition zone between 400 and $700 \mathrm{~km}$ depth is a more rewarding field for study in terms of finding potential matches for phase changes in plausible peridotite mineralogy. That this region was anomalous and required phase and/or 
compositional changes to explain the rapid increase of seismic wave velocity was known since at least Birch's (1952) study. Bernal (1936) suggested that olivine, the most abundant constituent of peridotite, could undergo a phase transition to a denser, seismically faster spinel structure with increasing pressure. Thus early interest in finding explanations for the transition zone focused on evaluating whether or not the pressure range and sharpness of the phase transition were appropriate. Ringwood (1962, 1963) demonstrated experimentally that $\mathrm{Ni}$ and Co silicate olivines did collapse with pressure to spinel but at pressures too low to be relevant to the transition zone between 400 and $700 \mathrm{~km}$ depth. These lower-pressure analogs for the $\mathrm{Mg}$-silicate spinel appropriate to peridotite compositions were first explored because their experimental transition pressures were achievable with devices available at the time. Ringwood and Major (1966) eventually prepared $\mathrm{Mg}-\mathrm{Fe}$ silicate spinel solid solutions using an internally-heated Bridgman anvil apparatus at roughly 150-200 kbar although the pressures were poorly known. They also documented that the transition from olivine to spinel in Mg-rich olivines proceeded through an intermediate, distorted spinel form ( $\beta$ spinel) eventually designated wadsleyite when found as a mineral in the Peace River meteorite (Price et al., 1983). Thus interest in the Earth's transition region as the locus of the olivine-spinel phase transition in olivine was rewarded by a rough but plausible match in pressure, but tempered with the possibility that any straightforward phase change explanation would be complicated with additional phase transitions. Akimoto and Fujisawa (1966), in the same issue of Earth and Planetary Science Letters as Ringwood and Major, produced a P-X phase diagram at $800{ }^{\circ} \mathrm{C}$ for the Fe-rich half of the $\mathrm{Fe}-\mathrm{Mg}$ silicate olivines using a tetrahedral anvil apparatus. Clearly their pressure-temperature control was superior to that of Ringwood and Major because they demonstrated a coherent P-X loop topology and compositional separation between olivines and coexisting spinels. [It is difficult to overstate the importance of $\mathrm{Fe}-\mathrm{Mg}$ solution effects in silicate and oxide solutions, especially the compositional separations between phases that are inherent. The implications and the treatment of this exchange for the olivine solution series with coexisting magmatic liquids were given a substantial boost by Roeder and Emslie (1970).] The impact of this demonstration for the seismic transition zone from 400 to $700 \mathrm{~km}$ depth is that any phase transitions of this sort are not expected to be sharp but to be smeared by compositional effects. This is not necessarily a negative impact any more than the discovery of wadsleyite can be construed to be negative. After all, the transition zone is both stepped and smooth in structure over its large depth range. A double P-X loop topology for the Mg-rich end of the olivines at 1200 and $1600{ }^{\circ} \mathrm{C}$ was presented by Katsura and Ito (1989) using octahedral multi-anvil apparatus reinforcing these points. Anderson (1989) and Agee (1998) have provided good reviews and syntheses of these results and scrutinized the closeness of match between the experimental phase transitions and the seismic counterparts. The start of the transition zone at $410 \mathrm{~km}$ probably corresponds to the onset of olivine collapse to wadsleyite and the minor discontinuity at $510 \mathrm{~km}$ may cor- respond to the start of the transition of wadsleyite to spinel. However there seems to be more structure to the transition zone than just these two phase changes, neither of which provide a good explanation for the major, sharp jump in seismic velocities at 660 $\mathrm{km}$ depth marking the transition from the upper mantle to the lower mantle. A possible explanation for this deeper major transition is the discovery that $\mathrm{Mg}_{2} \mathrm{SiO}_{4}$ disproportionates into $\mathrm{MgSiO}_{3}$ perovskite plus $\mathrm{MgO}$ at pressures in excess of $22 \mathrm{GPa}$ (Liu, 1975, 1976, using diamond anvil cells; Ito, 1977, using split sphere sliding anvil device). We will examine this below in detail. However there is more to mantle peridotite than just olivine. And there is no a priori reason that the transition zone might not also be compositionally different from the mantle above it. A theme consistently advocated by Bass and Anderson (1984), Duffy and Anderson (1989), and Anderson (1989) is that the transition region of Earth is better matched in its seismic properties by garnet and metasilicate species like pyroxene and its pressure-derivative structures, than by orthosilicates like olivine and spinel. This would mean that some of the increase in seismic velocity, beyond that expected for a self-compressing homogeneous medium, could be accommodated by changes in material constitution.

It is worth emphasizing that the experimental exploration of mantle transition zone candidate phase changes proceeded in concert with the development of the technical capabilities to do the research. The development of three technologies during this review period was instrumental in the research effort. We have mentioned the development of piston-cylinder technology (Boyd and England, 1960) in regard to the studies of basalt melting and MOHO transitions. However to access transition zone pressures up to $300 \mathrm{kbar}$, different styles of device were needed. Diamond anvil cells provided many pioneering glimpses of new phase changes in this era. The review of the development process by Bassett (2009) is highly recommended for its historic $\equiv$ ight and for its appropriateness coming from one of the fields $\overline{\overline{k e}}$ ding founders. Likewise the review of the development of the various multi-anvil solid media devices by Liebermann (2011) is highly recommended for the same reasons. The bulk of the detailed studies of candidate transition zone mineral phase changes and their compositional dimensions were undertaken with multianvil devices. The two-stage octahedron within cube geometry of Kawai and Endo (1970) for this style of device has gained wide acceptance throughout both the earth science and materials community, often with simplifications to the anvil-driving structure (Ohtani et al., 1987; Walker et al., 1990).

The phase transitions in the next most abundant components of peridotite, the metasilicate pyroxenes, are numerous and of considerable interest in understanding the additional structure present in the transition zone-whether or not they are the major constituents there as advocated by Anderson (1989). $\mathrm{MgSiO}_{3}$ forms single-chain pyroxene structures at low pressures. Octahedral chain-linking sites for $\mathrm{Mg}$ reorient from the orthorhombic form to the monoclinic form at $\sim 10 \mathrm{GPa}$ near the melting point. However a more interesting reorganization of the $\mathrm{MgSiO}_{3}$ structure was shown experimentally by Kato and Kumazawa (1985) to be to 
non-cubic garnet (majorite) at pressures near $20 \mathrm{GPa}$ in the liquidus region. The pressure region of 15-20 GPa at temperatures well below the liquidus first produces disproportionation of pyroxene into stishovite and $\beta$-spinel (then $\gamma$-spinel) followed by a recombination to the ilmenite structure at $\sim 20 \mathrm{GPa}$ (Kawai et al., 1974; Akaogi et al., 1987). These transitions were shown in their Mg-Fe variational details by Ohtani et al. (1991). Evidently the prediction of J.B. Thompson noted by Birch (1952) that upper mantle silicates might begin to form dense mixed oxides like rutile-structured $\mathrm{SiO}_{2}$ and corundum is partly realized. Stishovite is rutile-structured $\mathrm{SiO}_{2}$ and ilmenite is layer-ordered corundum structure.

Ito and Yamada (1982) showed that $\mathrm{MgSiO}_{3}$ ilmenite gave way to $\mathrm{MgSiO}_{3}$ perovskite above $\sim 25 \mathrm{GPa}$. This perovskite occurrence was not surprising given the previous demonstrations of Liu $(1975,1976)$ and Ito (1977) that orthosilicate compositions like $\mathrm{Mg}_{2} \mathrm{SiO}_{4}$ disproportionate at these pressures to $\mathrm{MgO}$ in rock salt structure and to metasilicate $\mathrm{MgSiO}_{3}$ in a perovskite structure. The first surprising aspect of this discovery was that $\mathrm{Mg}$ and $\mathrm{Si}$ were not separating into oxides but were reamalgamating into a single phase with different higher coordinations with oxygen in the perovskite structure: not the Thompsonian expectation of mixed oxides which was previously observed at lower pressures. What was also surprising was that the boundary introducing perovskite at the expense of ilmenite $\mathrm{MgSiO}_{3}$ has a negative $\mathrm{P}-\mathrm{T}$ Clapeyron slope unlike almost all the other high-pressure phasechange boundaries. Ito and Takahashi (1989) examined the $\mathrm{MgSiO}_{3}$ boundary in some detail as well as the disproportionation boundary between $\mathrm{Mg}_{2} \mathrm{SiO}_{4}$ spinel and perovskite+periclase. The boundaries introducing perovskite from orthosilicate and metasilicate compositions both have negative slopes. Furthermore, the positions of these two different perovskite boundaries are very close to one another in $\mathrm{T}$ and $\mathrm{P}$. And even more surprising, there was almost no effect of $\mathrm{Mg}$-Fe substitution at the $\mathrm{Mg}$-rich end of the binary orthosilicate join on the transition pressure over the full range of temperature investigated. (This later result becomes clouded when alumina is involved in the transition [Wood and Rubie, 1996).])

What does all this mean? There are answers at several levels. The lack of $\mathrm{Mg}$-Fe variation on the pressure of transition is part and parcel of little if any $\mathrm{Mg}$-Fe partitioning between perovskite and its precursor orthosilicates. The pressure transition is almost degenerate in composition at the temperatures investigated. This has the effect of reducing the extent to which the seismic transition would be spread in depth by solution effects, rendering the sharpness of the seismic transition explicable. This is quite unlike the olivine to spinel transition with strong $\mathrm{Mg}$-Fe fractionation between the olivines and spinels in equilibrium with each other. (See Fei [1998] for a good review of Fe-Mg partitioning relations in these phases.) The fact that both ortho and metasilicate precursors share a very similar pressure threshold for achieving perovskites also contributes to the potential sharpness expected for the transition. That the pressure is a good match for the $660 \mathrm{~km}$ discontinuity depth encourages the view that perovskite formation is the threshold signal for entry into the lower mantle. It does not matter if both ortho and metasilicate constituents are present because they both form perovskite at quite similar pressures. The formation of perovskite instead of mixed $\mathrm{SiO}_{2}$ and $\mathrm{MgO}$ oxides is a measure of the great stability of the perovskite structure. This is of course also known from the very wide range of compounds that do form in this structure at a variety of pressures including atmospheric. The lack of Mg-Fe partitioning on the formation of perovskite is a related symptom of its great stability, which is independent of the details of the specific ingredient list. The successful explanation for the sharpness of the phase change and its insensitivity to composition comes with a price. There is then less opportunity to look for compositional discriminants in the structure of the base of the transition zone. Finally the negative P-T slopes of the perovskite-entry curves formally mean that the entropy (and heat capacity) of perovskite is greater than its precursors given that they are less dense. The greater heat capacity of perovskite can be understood in terms of its structure. Eight fully corner-shared $\mathrm{Si}-\mathrm{O}$ octahedra surround a larger 12-coordinated $\mathrm{Mg}$ cavity. The flexibility of the corner-shared Si-O-Si octahedral linkages means that individual bending modes between octahedra and torsion modes of vibration of columns of octahedral in all three dimensions (for the cubic perovskite forms) are available to absorb thermal energy. The higher heat capacity resulting from this structure means that, for the precursors and the perovskites to be at the same temperature at equilibrium and for a transfer of precursor to perovskite to occur, thermal energy must be added. The precursor-to-perovskite transition with increasing pressure should be endothermic, a proposition confirmed calorimetrically by Ito et al. (1990). In a convecting system, descending parcels of precursor approaching the perovskite-in boundary at the top of the lower mantle will fall to lower temperature as they begin phase conversion. This conversion of sensible to latent heat will return them to the stability field of the precursor and so the transformation to perovskite will be inhibited. The denser perovskite in the lower mantle then is able to buoyantly resist the further descent of the sinking parcel. Whether the parcel will stagnate and fail to penetrate into the lower mantle or simply slow its descent depends on the details of the phase change slope and the adiabatic descent path (Verhoogen, 1965). Ito et al. (1990) felt that this effect might be more than a speed bump to descending parcels attempting to sink across the $660 \mathrm{~km}$ discontinuity at the top of the upper mantle because the negative slope was close to the critical one for inhibiting convection. However, the experimental uncertainty and possibly local variations in the seismic transition did not preclude whole-mantle convection.

Sherman (1988) alerted the community to the possibility that electronic spin states of Fe might give an important twist to the physical and chemical properties of Fe-bearing minerals in the lower mantle. The expected smaller effective ionic radius of $\mathrm{Fe}^{+2}$ in a low spin state leads to the expectation that high pressures in the lower mantle might stabilize the low spin state which should then produce minerals of higher density. The expected transitions may not be sharp and first order. To the extent that Fe-Mg partitioning is governed by the relative ionic radii of $\mathrm{Fe}$ and $\mathrm{Mg}$, partitioning 
between mineral phases could shift with the spin transition. To the extent that magnetic moments are supported by the high spin configuration, magnetic collapse might be another symptom to aid recognition of the transition to the low spin state, if density changes are not resolvable. Significant interest in these potential transitions was most economically generated through the high resolution studies of X-ray emissions (XES) near the Fe-K $\beta$ line, a satellite of which is sensitive to local magnetic states. Supplementary studies of compressional and Mossbauer responses have added additional criteria for evaluating the effects encountered.

$\mathrm{Li}$ et al. (2004) used XES to show that Al-bearing Mg-Fe perovskites did in fact undergo a gradual diminution of spin state as pressure approached $100 \mathrm{GPa}$. Thus the most important mineral of the lower mantle was put into play as a potential spin transition host - in the pressure range of the lower mantle. However the very gradual nature of the magnetic transition observed by $\mathrm{Li}$ et al. (2004) for abundant perovskite does not encourage the expectation of a seismic transition. In fact, none is observed in the pressure range of the spin change. Li et al. (2006) went on to show that the transition in perovskite was quite gradual, not only because of the presence of a number of spin states but also because of the presence of a number of sites populated by a number of Fe valencies in the run up to $100 \mathrm{GPa}$. Subsequently Lin et al. (2008) explored the high-temperature domain in both perovskites and post-perovskites, confirmed the mixed states present and concluded that the perovskite to post-perovskite transition would be a more important influence on such properties as $\mathrm{Fe}-\mathrm{Mg}$ partitioning and radiative thermal conductivity than would be the spin state of $\mathrm{Fe}^{2+}$. In a companion paper, McCammon et al. (2008) showed that the intermediate spin state was stable in perovskites throughout the full range of lower mantle pressures, and that the intermediate spin state was stabilized by high temperature. This raised the possibility that slab and plume thermal anomalies would be more likely to be visible as seismic heterogeneities than would pressure-induced spin transitions appear as seismic discontinuities. Mao et al. (2011) showed no anomalies in the compression of iron-bearing perovskite across the spin transition but have made the suggestion that the transition to low spin state in Fe-bearing perovskites at deep lower mantle pressures could be responsible for some of the anomalously slow shear wave regions there. Clearly the spin transitions in perovskites are not expected to cause lower mantle seismic discontinuities of the sharp phase-change sort.

Badro et al. (2003) studied the second most important lower mantle mineral, ferropericlase, by XES in diamond anvil cells and found a spin transition in the 60-70 Gpa pressure range. The relative sharpness of the magnetic collapse in ferropericlase was in contrast to a gradual shift in perovskite. Badro et al. (2003) did not advocate any expectation of a seismically observable transition, because there was none observed. Instead they advocated, on the basis of a qualitative energy of partitioning model, that ferropericlase might be expected to drain coexisting perovskites of their $\mathrm{Fe}^{2+}$ upon achieving a low spin state. The qualitative model has since been shown to be faulty and no such partitioning swing has been confirmed. Shortly thereafter, Lin et al. (2005) investigated ferropericlase by XES and X-ray diffraction (XRD) compression studies in diamond anvil cells. They also recovered a relatively sharp magnetic collapse near 60-70 GPa, with a jump in the bulk modulus, but they reported no significant volume drop at the transition. Subsequently Crowhurst et al. (2008) reinterpreted the Lin et al. data to show a gradual anomalous volume drop with spin transition by readjusting the start of the transition pressure to more like $40 \mathrm{GPa}$. Crowhurst et al. (2008) also used impulsively stimulated scattering to show modulus softening across the spin transition, leading to the expectation that both compressional and shear velocities for this phase in the lower mantle would be anomalously slow. Ito (2012) has studied the same composition of ferropericlase $\left(\mathrm{Mg}_{0.83} \mathrm{Fe}_{0.17} \mathrm{O}\right)$ by multi-anvil XRD compression methods with Kawai geometry using sintered diamond anvils and found, in contrast to Lin et al. (2005), a noticeable but gradual volume drop across the transition seen in a similar pressure range as the transition seen by Lin et al. (2005). The bandwidth of the spin transition in ferropericlase, although sharper than for perovskite, is still not sharp enough to be responsible for any seismic transitions in the very deep mantle like $\mathrm{D}^{\prime \prime}$, although it may contribute to some broad, anomalous shear wave velocity gradients and shear wave anisotropy (Antonangeli et al., 2011) throughout the lower mantle.

The complacent state of mantle phase change petrology was jolted back into the spotlight in 2004 when two separate groups simultaneously reported that perovskite underwent a previously undocumented further phase change with pressure equivalent to depths not far above the core-mantle boundary. Such a phase change was anticipated from the seismic studies of the $\mathrm{D}^{\prime \prime}$ layer by Sidorin et al. (1998). Murakami et al. (2004) used laser-heated diamond anvil cells and synchrotron X-ray diffraction to demonstrate experimentally the growth of a new orthorhombic $\mathrm{Cmcm}$ form of $\mathrm{MgSiO}_{3}$ at $125 \mathrm{GPa}$ and $2500 \mathrm{~K}$. The new phase was isostructural with $\mathrm{CaIrO}_{3}$ having sheets of $\mathrm{SiO}_{6}$ octahedra separated by layers of $\mathrm{Mg}$ cations in 8-fold coordination cross linking the octahedral sheets. Within the octahedral sheets, parallel but alternately rotationally tilted columns of edge-shared octahedra were connected to each other by corner sharing (Fig. 9). This same structure was predicted by ab initio simulations to exist for $\mathrm{MgSiO}_{3}$ and was also confirmed experimentally by Oganov and Ono (2004) following the observation by Ono of a similar structure at lower pressure in $\mathrm{Fe}_{2} \mathrm{O}_{3}$. The successful prediction of this structure for $\mathrm{MgSiO}_{3}$ in the experimentally confirmed pressure field indicates that $a b$ initio calculations are ready to take a place in the petrologist's quantitative tool box. The convergence and agreement about the identity and threshold pressure for formation of the new phase across the two studies was remarkable. That it matched the hypothetical phase change projected by Sidorin et al. (1998) from their seismological study of D" at the base of the mantle was most gratifying. The structural anisotropy of the new post-perovskite phase provides an explanation for the seismic anisotropy found in $\mathrm{D}^{\prime \prime}$ if preferred orientation of the mineral grains can be achieved. 
The pressure sequence of structures assumed by $\mathrm{MgSiO}_{3}$ may be extrapolated with caution. At zero pressure, single chains of corner-shared $\mathrm{SiO}_{4}$ tetrahedra characterize the orthorhombic then monoclinic pyroxene structures. At pressures characteristic of the transition zone in Earth, pyroxene disproportionates at temperatures below the melting point into stishovite and spinels. At the base of the transition zone, both $\mathrm{Si}$ and $\mathrm{Mg}$ in the ilmenite structure are fully octahedral. Collapse to the perovskite structure increases $\mathrm{Mg}$ coordination to 8 (or 12 if cubic perovskite), $\mathrm{Si}$ remains 6-coordinated, and the $\mathrm{Si}$ octahedra are all corner shared. The next densification of structure achieved by the transformation to post-perovskite is through rearrangement of the $\mathrm{Si}$ corner-shared octahedral framework into sheets of edge and corner shared Si octahedra. Although Earth has little further pressure to apply to silicates in the mantle, it is worth considering what would be the mode of densification within a larger terrestrial silicate planet if one were to exist? Numerous terrestrial-like exoplanets significantly larger than Earth do exist in other solar systems (Hand, 2011). Several potential modes of densification are available beyond the simple expedient of self-compression in the same mineralogical structure. For instance the transfer from edge sharing of the silica octahedra that form sheets to face-sharing

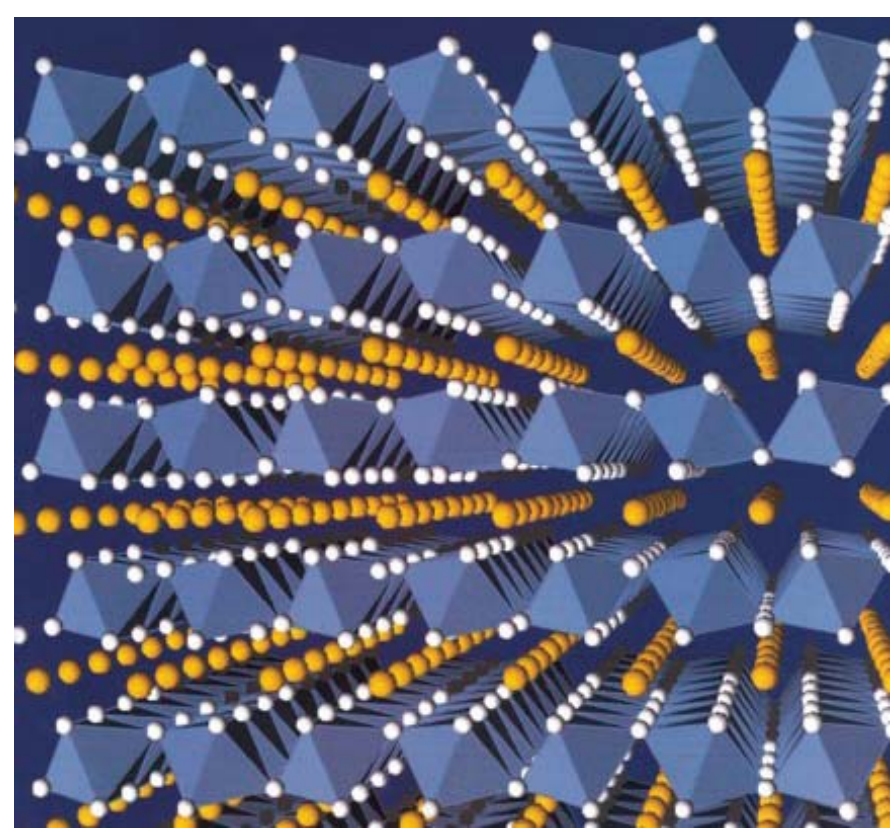

Figure 9. Postperovskite structure illustrated by Murakami et al. (2004), also discovered by Oganov and Ono (2004). Figure reused with publisher's permission. Horizontal blue sheets of $\mathrm{SiO}_{6}$ octahedral groups are edge-shared into the page and corner shared horizontally. Oxygens are white balls, $\mathrm{Mg}$ yellow. The edge-shared linkages are alternately twisted so that the $\mathrm{Si}-\mathrm{O}-\mathrm{Si}$ bonds through the corner share are not $180^{\circ}$. This distortional twist may be the precursor to the octahedral sheets breaking up into separate horizontal chains of faceshared octahedra within the plane of the image. Such an inversion to a denser $\mathrm{Mg}$ silicate structure may be realized in exoplanets larger than Earth. Structures of this type are known to exist at high pressures in the Ca-Sr-Pd oxides (Wang et al., 1999). chains of octahedra could be imagined. The crinkled nature of the sheets in the post-perovskite structure is a preliminary distortion that could lead to face-sharing of octahedra when the edge-shared links disengage. A number of high-pressure $\mathrm{Ca}-\mathrm{Sr}-$ Pd oxides have this basic face-shared, octahedral chain structure (Wang et al., 1999). Variants in the structure are introduced by having the octahedra alternate along the length of the chain with triangular prisms that are also 6-coordinated. This, of course, is not the only speculative suggestion that could be offered for "the next big phase change," which might occur given a sufficiently large silicate planet. It is offered with a sense of adventure but it is based on reasonable crystal chemistry and some non-geological precedents. It is highly likely that further structural modifications to denser phases than post-perovskite do come into play on super-Earths, whether or not the Ca-Sr-Pd oxides are an appropriate model. More layers in a planet provide more opportunities for additional modes of differentiation behavior.

\section{EARTH'S CORE-THE LAST (UNCROSSED) PETROLOGICAL FRONTIER}

The Earth's core is known through seismology to be layered into a solid inner core and a liquid outer core which is kept partially molten by alloying with light elements. Whatever the merits of the silicate magma ocean scenario for the early Earth may have been, there is currently a buried metal magma ocean surrounding the inner core. The fossil cores of small ancient planets have been sampled in our collections of iron meteorites. These extraterrestrial objects provide an extraordinary display, a virtual laboratory, of fractionation of trace elements through solid metal crystallization (Wasson et al., 1980; Pernicka and Wasson, 1987; Wasson, 1999). There is every reason to expect that such an experiment is in progress now in the Earth' core-but at a much higher pressure so that kamacite and taenite are not the relevant solid Fe polymorphs crystallizing (Fig. 3). This experiment has been in progress for a much longer time and at much higher temperature than for the iron meteorites, so that reequilibration between the liquid and a large fraction of the solid may have occurred, leading to a qualitatively different outcome than for the magmatic iron meteorites. The nature of the light elements in the liquid outer core is much debated around the leading possibilities of $\mathrm{S}, \mathrm{C}, \mathrm{H}, \mathrm{Si}$, and $\mathrm{O}$ or some mix of all of them. Phase relations for even binary systems with $\mathrm{Fe}$ at megabar pressures, that might be useful for constraining the light element possibilities or core dynamics, are unknown (at best). The identity and concentration of light elements in liquid metal has a profound effect upon the geochemical partitioning behavior of the system during solidification (Jones and Malvin, 1990). Thus it is difficult to anticipate exactly what fractionations in what order might be expected to be occurring in detail in the core. The modeling of core magnetodynamics is currently good enough to have predictive power (Glatzmaier and Roberts, 1995) for such effects as inner core super-rotation (Song and Richards, 1996). However, the controversy over the identity of the iron 
polymorph that constitutes the solid inner core (Boehler, 2000) have not fully abated, even though Asanuma et al. (2011) have shown the hexagonal close packed (HCP) form to be experimentally stable to inner core pressures for two plausible alloy compositions. It seems premature to offer speculation into the core's chemical dynamics when even the identity of the Fe polymorph of the inner core is still not known in a state where significant discrepancies between alternatives remain unresolved (Komabayashi and Fei, 2010). Instead we refer to Li and Fei (2003) as a guide to what might follow in future research to understand the core. And we can anticipate developments.

\section{CONCLUSIONS}

Many broad aspects of the Earth's petrological workings have become understood in the past 50 years. Many details and alternative views of specific issues remain unresolved. When will the planetary differentiation process stagnate? Do the mantle's deep phase changes also have a compositional dimension, delimiting regions of different compositions? Are there plumes? Will large exoplanets of terrestrial-like composition have new modes of layering and behavior? It would be surprising if a review in 50 years' time did not have a similar conclusion to this review: progress has been made, but the whole job is still not done.

\section{ACKNOWLEDGMENTS}

I thank ME Bickford for the invitation to participate in this celebration of GSA's 125th anniversary. I thank my colleagues D. Ebel, T.M. Harrison, P. Kelemen, J. Li, E.A. Mathez, and T.A. Plank for their guidance about the important issues of the past 50 years of petrology. I thank reviewers B.D. Marsh, S.A. Morse, and D.C. Presnall for their review comments and for their tolerance of the selectivity of this review, even if it was painful for them. I thank my sponsors over the years at NSF, NASA, and DOE who have enabled my participation in this field. I also thank my home institutions at Columbia University, the Department of Earth and Environmental Sciences and the Lamont-Doherty Earth Observatory, for providing a supportive environment from which to participate.

\section{REFERENCES CITED}

Agee, C.B., 1998, Phase transformations and seismic structure in the upper mantle and transition zone, in Hemley, R.J., ed., Ultrahigh-pressure mineralogy: physics and chemistry of the Earth's deep interior: Reviews in Mineralogy, v. 37, p. 165-203.

Agee, C.B., and Walker, D., 1988, Static compression and olivine flotation in ultrabasic silicate liquid: Journal of Geophysical Research, v. 93, p. 3437-3449, doi:10.1029/JB093iB04p03437.

Akaogi, M., Navrotsky, A., Yagi, T., Akimoto, S. 1987, Pyroxene-garnet transformation: thermochemistry and elasticity of garnet solid solutions, and application to a pyrolite mantle, in Manghnani, M.H., and Syono, Y., eds., High-Pressure Research in Mineral Physics: Tokyo, Terra Publications, p. 251-260.

Akimoto, S., and Fujisawa, H., 1966, Olivine-spinel transition in $\mathrm{Mg}_{2} \mathrm{SiO}_{4}$ $\mathrm{Fe}_{2} \mathrm{SiO}_{4}$ at $800^{\circ} \mathrm{C}$ : Earth and Planetary Science Letters, v. 1, p. 237-240, doi:10.1016/0012-821X(66)90076-8.
Amelin, Y., Connelly, J., Zartman, R.E., Chen, J.H., Gopel, C., and Neymark, L.A., 2009, Modern U-Pb chronometry of meteorites: advancing to higher time resolution reveals new problems: Geochimica et Cosmochimica Acta, doi:10.1016/j.gca.2009.01.040.

Anderson, D.L., 1989, Theory of the Earth: Blackwell Scientific Publications, Boston, $336 \mathrm{p}$.

Anderson, D.L., 2012, Questioning mantle plumes: Physics Today, v. 65, doi:10.1063/PT.3.1732.

Antonangeli, D., Siebert, J., Arachne, C.M., Farber, D.L., Bosak, A., Hoesch, M., Krisch, M., Ryerson, F.J., Fiquet, G., and Badro, J., 2011, Spin crossover in ferropericlase at high pressure: a seismically transparent transition?: Science, v. 331, p. 64-67, doi:10.1126/science.1198429.

Armstrong, R.L., 1981, Radiogenic isotopes: the case for crustal recycling on a near-steady-state no-continental growth Earth: Philosophical Transactions of the Royal Society of London Series A, v. 301, p. 443-471, doi:10.1098/rsta.1981.0122.

Arndt, N., Lesher, C.M., and Barnes, S.J., 2008, Komatiite: Cambridge, 488 p. Asanuma, H., Ohtani, E., Sakai, T., Terasaki, H., Kamada, S., Hirao, N., and Ohishi, Y., 2011, Static compression of $\mathrm{Fe}_{0.83} \mathrm{Ni}_{0.09} \mathrm{Si}_{0.08}$ to $374 \mathrm{GPa}$ and $\mathrm{Fe}_{0.93} \mathrm{Si}_{0.07}$ to $252 \mathrm{GPa}$ : implications for the Earth's inner core: Earth and Planetary Science Letters, v. 310, p. 113-118, doi:10.1016/j .eps1.2011.06.034.

Aulbach, S., 2012, Craton nucleation and formation of thick lithospheric roots: Lithos, doi:10.1016/j.lithos.2012.02.011.

Badro, J., Fiquet, G., Guyot, F., Rueff, J.-P., Struzhkin, V.V., Vanko, G., and Monaco, G., 1993, Iron partitioning in Earth's mantle: Toward a deep lower mantle discontinuity: Science, v. 300, p. 789-791, doi:10.1126/ science. 1081311 .

Basaltic Volcanism Study Project, 1981, Basaltic Volcanism on the Terrestrial Planets: New York, Pergamon Press, Inc., 1286 p.

Bass, J.D., and Anderson, D.L., 1984, Composition of the upper mantle: geophysical tests of two petrological models: Geophysical Research Letters, v. 11, p. 229-232, doi:10.1029/GL011i003p00229.

Bassett, W.A., 2009, Diamond anvil cell, 50th birthday: High Pressure Research, v. 29, p. 163-186, doi:10.1080/08957950802597239.

Becker, R.H., and Pepin, R.O., 1984, The case for Martian origin of Shergottites: nitrogen and noble gases in EETA 79001: Earth and Planetary Science Letters, v. 69, p. 225-242, doi:10.1016/0012-821X(84)90183-3.

Bédard, J., Brouilette, P., Madore, L., and Berclaz, A., 2003, Archaean deformation and cratonization in the northern Superior province, Canada: and evaluation of plate tectonic versus vertical tectonic models: Precambrian Research, v. 127, p. 61-87, doi:10.1016/S0301-9268(03)00181-5.

Bernal, J.D., 1936, Geophysical discussion: Observatory, v. 59, p. 268.

Bernstein, S., Kelemen, P.B., and Brooks, K.C., 1998, Depleted spinel harzburgite xenoliths in Tertiary dikes from east Greenland: restites from high degree melting: Earth and Planetary Science Letters, v. 154, p. 221-235, doi:10.1016/S0012-821X(97)00175-1.

Bernstein, S., Kelemen, P.B., and Hanghoj, K., 2007, Consistent Mg\# in cratonic mantle reflects Archean mantle melting to the exhaustion of orthopyroxene: Geology, v. 35, p. 459-462, doi:10.1130/G23336A.1.

Best, M.G., 2003, Igneous and Metamorphic petrology, 2nd ed.: Blackwell Science Ltd., 729 p.

Bickford, M.E., 1988, The formation of continental crust: Part 1. A review of some principles; Part 2. An application to the Proterozoic evolution of southern North America: Geological Society of America Bulletin, v. 100, p. 1375-1391, doi:10.1130/0016-7606(1988)100<1375:TFOCCP>2.3.CO;2.

Bina, C.R., 1998, Lower mantle mineralogy and the geophysical perspective, in Hemley, R.J., Ultrahigh-pressure mineralogy: physics and chemistry of the Earth's deep interior: Reviews in Mineralogy, v. 37, p. 205-239.

Birch, F., 1952, Elasticity and constitution of the Earth's interior: Journal of Geophysical Research, v. 57, p. 227-286, doi:10.1029/JZ057i002p00227.

Birck, J.L., and Allègre, C.J., 1978, Chronology and chemical history of the parent body of basaltic achondrites studied by the $\mathrm{Rb}-\mathrm{Sr}$ method: Earth and Planetary Science Letters, v. 39, p. 37-51, doi:10.1016/0012 $-821 \mathrm{X}(78) 90139-5$.

Boehler, R., 2000, High-pressure experiments and the phase diagram of lower mantle and core materials: Reviews of Geophysics, v. 38, p. 221-245, doi:10.1029/1998RG000053.

Bogard, D.D., Nyquist, L.E., and Johnson, P., 1984, Noble gas contents of Shergottites and implications for the Martian origin of SNC meteorites: Geochimica et Cosmochimica Acta, v. 48, p. 1723-1739, doi:10.1016/0016 -7037(84)90028-0. 
Borg, L.E., Connelly, J.N., Boyet, M., and Carlson, R.W., 2011, Chronological evidence that the Moon is either young or that it did not have a global magma ocean: Nature, v. 477, p. 70-72, doi:10.1038/nature10328.

Boyd, F.R., 1989, Compositional distinction between oceanic and cratonic lithosphere: Earth and Planetary Science Letters, v. 96, p. 15-26, doi:10.1016/0012-821X(89)90120-9.

Boyd, F.R., and England, J.L., 1960, Apparatus for phase equilibrium measurements at pressures to 50 kilobars and temperatures to $1750{ }^{\circ} \mathrm{C}$ : Journal of Geophysical Research, v. 65, p. 741-748, doi:10.1029/JZ065i002p00741.

Boyet, M., and Carlson, R.W., 2005, ${ }^{142} \mathrm{Nd}$ evidence for early ( $>4.53$ by ago) global differentiation of the silicate earth: Science, v. 309, p. 576-581, doi:10.1126/science.1113634.

Bowen, N.L., 1928, The evolution of the igneous rocks: Princeton, New Jersey, Princeton University Press, $334 \mathrm{p}$.

Campbell, I.H., and O'Neill, H.S.C., 2012, Evidence against a chondritic Earth: Nature, v. 483, p. 553-558, doi:10.1038/nature10901.

Campbell, I.H., Griffiths, R.W., and Hill, R.I., 1989, Melting in an Archean mantle plume: heads its basalts, tails its komatiites: Nature, v. 339, p. 697-699, doi:10.1038/339697a0.

Cann, J.R., 1970, A new model for the structure of the ocean crust: Nature, v. 226 , p. $928-930$, doi:10.1038/226928a0.

Carmichael, I.S.E., 1964, Petrology of Thingmuli, a Tertiary volcano in eastern Iceland: Journal of Petrology, v. 5, p. 435-460, doi:10.1093/ petrology/5.3.435.

Chappell, B.W., and White, A.J.R., 1974, Two contrasting granite types: Pacific Geology, v. 8, p. 173-174.

Clayton, R.N., 2008, Oxygen isotopes in the early solar system-a historical perspective: Reviews in Mineralogy and Geochemistry, v. 68, p. 5-14, doi:10.2138/rmg.2008.68.2.

Clayton, R.N., Grossman, L., and Mayeda, T.K., 1973, A component of primitive nuclear composition in carbonaceous meteorites: Science, v. 182, p. 485-488, doi:10.1126/science.182.4111.485.

Clayton, R.N., Onuma, N., Grossman, L., and Mayeda, T.K., 1977, Distribution of the presolar component in Allende and other carbonaceous chondrites: Earth and Planetary Science Letters, v. 34, p. 209-224, doi:10.1016/0012 $-821 \mathrm{X}(77) 90005-\mathrm{X}$

Cohen, L.H., Ito, K., and Kennedy, G.C., 1967, Melting and phase relations in an anhydrous basalt to 40 kilobars: American Journal of Science, v. 265, p. 475-518, doi:10.2475/ajs.265.6.475.

Coleman, R.G., 1977, Ophiolites: Berlin, Heidelberg, New York, SpringerVerlag, $299 \mathrm{p}$.

Condie, K.C., 1989, Plate tectonics and continental evolution, 3rd ed.: New York, Pergamon, $476 \mathrm{p}$.

Condie, K.C., Bickford, M.E., Aster, R.C., Belusova, E., and Scholl, D.W., 2011, Episodic zircon ages, Hf isotopic composition, and the preservation of continental crust: Geological Society of America Bulletin, v. 123, p. 951-957, doi:10.1130/B30344.1.

Connolly, J.A.D., 2005, Computation of phase equilibria by linear programming: a tool for geodynamic modeling and its application to subduction zone decarbonation: Earth and Planetary Science Letters, v. 236, p. 524541, doi:10.1016/j.eps1.2005.04.033.

Consolmagno, G.J., and Drake, M.J., 1977, Composition and evolution of the eucrite parent body: Geochimica et Cosmochimica Acta, v. 41, p. 12711282, doi:10.1016/0016-7037(77)90072-2.

Cook, D.L., Walker, R.J., Horan, M.F., Wasson, J.T., and Morgan, J.W., 2004, Pt-Re-Os systematic of group IIAB and IIIAB iron meteorites: Geochimica et Cosmochimica Acta, v. 68, p. 1413-1431, doi:10.1016/j .gca.2003.09.017.

Crowhurst, J.C., Brown, J.M., Goncharov, A.F., and Jacobsen, S.D., 2008, Elasticity of $(\mathrm{Mg}, \mathrm{Fe}) \mathrm{O}$ through the spin transition of iron in the lower mantle: Science, v. 319, p. 451-453, doi:10.1126/science.1149606.

Dasgupta, R., and Hirschmann, M.M., 2010, The deep carbon cycle and melting in Earth's interior: Earth and Planetary Science Letters, doi:10.1016/j .eps1.2010.06.039.

Dasgupta, R., Hirschmann, M.M., and Stalker, K., 2006, Immiscible transition from carbonate-rich to silicate-rich melts in the $3 \mathrm{GPa}$ melting interval of eclogite $+\mathrm{CO}_{2}$ and genesis of silica undersaturated ocean island lavas: Journal of Petrology, v. 47, p. 647-671, doi:10.1093/petrology/egi088.

Dasgupta, R., Hirschmann, M.M., and Smith, N.D., 2007a, Partial melting experiments of peridotite $+\mathrm{CO}_{2}$ at $3 \mathrm{GPa}$ and genesis of alkalic ocean island basalts: Journal of Petrology, v. 48, p. 2093-2124, doi:10.1093/ petrology/egm053.
Dasgupta, R., Hirschmann, M.M., and Smith, N.D., 2007b, Water follows carbon: $\mathrm{CO}_{2}$ incites deep silicate melting and dehydration beneath mid-ocean ridges: Geology, v. 35, p. 135-138, doi:10.1130/G22856A.1.

Dasgupta, R., Jackson, M.G., and Lee, C.-T.A., 2010, Major element chemistry of ocean island basalts - conditions of mantle melting and heterogeneity of mantle source: Earth and Planetary Science Letters, v. 289, p. 377-392, doi:10.1016/j.epsl.2009.11.027.

Davies, G.F., and Richards, M.A., 1992, Mantle convection: The Journal of Geology, v. 100, p. 151-206, doi:10.1086/629582.

DePaolo, D.J., 1981, Trace element effects of combined wallrock assimilation and fractional crystallization: Earth and Planetary Science Letters, v. 53, p. 189-202, doi:10.1016/0012-821X(81)90153-9.

Duffy, T.S., and Anderson, D.L., 1989, Seismic velocity in mantle minerals and the mineralogy of the upper mantle: Journal of Geophysical Research, v. 94, B2, p. 1895-1912, doi:10.1029/JB094iB02p01895.

Duke, M.B., and Silver, L.T., 1967, Petrology of eucrites, howardites, and diogenites: Geochimica et Cosmochimica Acta, v. 31, p. 1637-1665, doi:10.1016/0016-7037(67)90112-3.

Dungan, M.A., and Rhodes, J.M., 1978, Residual glasses and melt inclusions in basalts from DSDP legs 45 and 46: evidence for magma mixing: Contributions to Mineralogy and Petrology v. 67, p. 417-431, doi:10.1007/ BF00383301.

Dziewonski, A.M., and Anderson, D.L., 1981, Preliminary reference Earth model: Physics of the Earth and Planetary Interiors, v. 25, p. 297-356, doi:10.1016/0031-9201(81)90046-7.

Eby, G.N., 1987, The Monteregian Hills and White Mountain alkaline igneous provinces, eastern North America, in Fitton, J.G., and Upton, B.G.J., eds., Alkaline Igneous Rocks: Geological Society of London Special Publication 30, p. 433-447.

Eby, G.N., 1990, The A-type granitoids: A review of their occurrence and chemical characteristics and speculations on their petrogenesis: Lithos, v. 26, p. 115-134, doi:10.1016/0024-4937(90)90043-Z.

Echeverria, L.M., 1980, Tertiary or Mesozoic komatiites from Gorgona Island, Colombia: field relations and geochemistry: Contributions to Mineralogy and Petrology v. 73, p. 253-266, doi:10.1007/BF00381444.

Engel, A.E.J., and Engel, C.G., 1964, Composition of basalts from the mid-Atlantic Ridge: Science, v. 144, p. 1330-1333, doi:10.1126/ science.144.3624.1330.

Engel, A.E.J., Engel, C.G., and Havens, R.G., 1965, Chemical characteristics of oceanic basalts and the upper mantle: Bulletin of the Geological Society of America v. 76, p. 719-734, doi:10.1130/0016-7606(1965)76[719 :CCOOBA $2.0 . \mathrm{CO} ; 2$.

Farquhar, J., Bao, H., and Thiemens, M.H., 2000, Atmospheric influence of Earth's earliest sulfur cycle: Science, v. 289, p. 756-758, doi:10.1126/ science. 289.5480 .756

Farquhar, J., Wu, N.P., Canfield, D.E., and Oduro, H., 2010, Connections between sulfur cycle evolution, sulfur isotopes, sediments, and base metal deposits: Economic Geology and the Bulletin of the Society of Economic Geologists, v. 105, p. 509-533, doi:10.2113/gsecongeo.105.3.509.

Fei, Y., 1998, Solid solutions and element partitioning at high pressures and temperatures, in Hemley, R.J., ed., Ultrahigh-pressure mineralogy: physics and chemistry of the Earth's deep interior: Reviews in Mineralogy, v. 37 , p. $344-367$.

Fenner, C.N., 1929, The crystallization of basalts: American Journal of Science, v. 18 , p. 225-253, doi:10.2475/ajs.s5-18.105.225.

Fitton, J.G., and Dunlop, H.M., 1985, The Cameroon line, West Africa, and its bearing on the origin of oceanic and continental alkali basalt: Earth and Planetary Science Letters, v. 72, p. 23-38, doi:10.1016/0012 $-821 X(85) 90114-1$.

Foulger, G.R., 2010, Plates vs. plumes: a geological controversy: WileyBlackwell, $364 \mathrm{p}$

Fyfe, W.S., 1978, The evolution of Earth's crust: modern plate tectonics to ancient hot spot tectonics?: Chemical Geology, v. 23, p. 89-114, doi:10.1016/0009-2541(78)90068-2.

Gerbode, C., and Dasgupta, R., 2010, Carbonate-fluxed melting of MORB-like pyroxenite at $2.9 \mathrm{GPa}$ and genesis of HIMU ocean island basalts: Journal of Petrology, v. 51, p. 2068-2088, doi:10.1093/petrology/egq049.

Ghiorso, M.S., and Sack, R.O., 1995, Chemical mass transfer in magmatic processes IV: A revised and internally consistent thermodynamic model for the interpolation and extrapolation of liquid-solid equilibria in magmatic systems at elevated temperatures and pressures: Contributions to Mineralogy and Petrology, v. 119, p. 197-212, doi:10.1007/BF00307281. 
Gill, R., 2010, Igneous rocks and processes: a practical guide: Wiley-Blackwell, $440 \mathrm{p}$.

Glatzmaier, G.A., and Roberts, P.H., 1995, A three-dimensional self-consistent computer simulation of a geomagnetic field reversal: Nature, v. 377, p. 203-209, doi:10.1038/377203a0.

Goldstein, J.I., and Ogilvie, R.E., 1965, The growth of the Widmanstaatten pattern in metallic meteorites: Geochimica et Cosmochimica Acta, v. 29, p. 893-920, doi:10.1016/0016-7037(65)90085-2.

Gray, C.M., and Compston, W., 1974, Excess ${ }^{26} \mathrm{Mg}$ in the Allende meteorite: Nature, v. 251, p. 495-497, doi:10.1038/251495a0.

Green, D.H., 1975, Genesis of Archaean peridotitic magmas and constraints on Archaean thermal gradients and tectonics: Geology, v. 3, p. 15-18, doi:10.1130/0091-7613(1975)3<15:GOAPMA >2.0.CO;2.

Green, D.H., and Ringwood, A.E., 1967a, The genesis of basaltic magmas: Contributions to Mineralogy and Petrology v. 15, p. 103-190, doi:10.1007/ BF00372052.

Green, D.H., and Ringwood, A.E., 1967b, An experimental investigation of the gabbro to eclogite transformation and its petrological applications: Geochimica et Cosmochimica Acta, v. 31, p. 767-833, doi:10.1016/S0016 -7037(67)80031-0.

Green, D.H., Nicholls, I.A., Viljoen, M., and Viljoen, R., 1975, Experimental demonstration of peridotitic liquids in earliest Archaean magmatism: Geology, v. 3, p. 11-14, doi:10.1130/0091-7613(1975)3<11:EDOTEO>2.0.CO;2.

Green, T.H., and Ringwood, A.E., 1968, Genesis of the calc-alkaline igneous rock suite: Contributions to Mineralogy and Petrology v. 18, p. 105-162, doi:10.1007/BF00371806

Greenbaum, D., 1972, Magmatic processes at ocean ridges: evidence from the Troodos massif, Cyprus: Nature, v. 238, p. 18-21.

Grew, E.S., Bada, J.L., and Hazen, R.M., 2011, Borate minerals and the origin of the RNA world: Origins of Life and Evolution of the Biosphere, v. 41, p. 307-316, doi:10.1007/s11084-010-9233-y.

Grossman, L., 1972, Condensation in the primitive solar nebula: Geochimica et Cosmochimica Acta, v. 36, p. 597-619, doi:10.1016/0016 -7037(72)90078-6.

Grossman, L., 1975, Petrography and mineral chemistry of inclusions Carich in the Allende meteorite: Geochimica et Cosmochimica Acta, v. 39, p. 433-454, doi:10.1016/0016-7037(75)90099-X.

Grove, T.L., and Baker, M.B., 1984, Phase equilibrium controls on the tholeiitic versus the calc-alkaline differentiation trends: Journal of Geophysical Research, v. 89, p. 3253-3274, doi:10.1029/JB089iB05p03253.

Grove, T.L., and Kinzler, R.J., 1986, Petrogenesis of andesites: Annual Review of Earth and Planetary Sciences, v. 14, p. 417-454, doi:10.1146/annurev. ea.14.050186.002221.

Grove, T.L., and Parman, S.W., 2004, Thermal evolution of the Earth as recorded by komatiites: Earth and Planetary Science Letters, v. 219, p. 173-187, doi:10.1016/S0012-821X(04)00002-0.

Grove, T.L., Gerlach, D.C., and Sando, T.W., 1982, Origin of calc-alkaline series lavas at Medicine Lake volcano by fractionation, assimilation and mixing: Contributions to Mineralogy and Petrology, v. 80, p. 160-182, doi:10.1007/BF00374893.

Grove, T.L., Till, C.B., and Krawczynski, 2012, The role of $\mathrm{H}_{2} \mathrm{O}$ in subduction zone magmatism: Annual Review of Earth and Planetary Sciences, v. 40, p. 413-439, doi:10.1146/annurev-earth-042711-105310.

Hacker, B.R., Kelemen, P.B., and Behn, M.D., 2011, Differentiation of continental crust by relamination: Earth and Planetary Science Letters, v. 307, p. 501-516, doi:10.1016/j.epsl.2011.05.024.

Hamet, J., Nakamura, N., Unruh, D.M., and Tatsumoto, M., 1978, Origin and history of the accumulate eucrite, Moama, as inferred from REE abundances, $\mathrm{Sm}-\mathrm{Nd}$ and $\mathrm{U}-\mathrm{Pb}$ systematic, in Proceedings, 9th Lunar and Planetary Science Conference, p. 1115-1136.

Hamilton, W.B., 1998, Archean magmatism and deformation were not products of plate tectonics: Precambrian Research, v. 91, p. 143-179, doi:10.1016/ S0301-9268(98)00042-4.

Hand, E., 2011, Super-Earths give theorists a super headache: Nature, v. 480, p. 302, doi:10.1038/480302a.

Hargraves, R.B., 1976, Precambrian geologic history: Science, v. 193, p. $363-$ 371, doi:10.1126/science. 193.4251 .363

Harrison, T.M., 2009, The Hadean crust: evidence from >4 Ga zircons: Annual Review of Earth and Planetary Sciences, v. 37, p. 479-505, doi:10.1146/ annurev.earth.031208.100151.

Haskin, L.A., Helmke, P.A., Blanchard, D.P., Jacobs, J.W., and Telander, K., 1974, Major and trace element abundances in samples from the lunar highlands, in Proceedings, 4th Lunar and Planetary Science Conference, p. $1275-1296$.

Hawkesworth, C.J., and Kemp, A.L.S., 2006, Using hafnium and oxygen isotopes in zircons to unravel the record of continental evolution: Chemical Geology, v. 226, p. 144-162, doi:10.1016/j.chemgeo.2005.09.018.

Hawkesworth, C.J., Dhuime, B., Pietranik, A.B., Kemp, A.J.S., and Storey, A.J.S., 2010, The generation and evolution of continental crust: Journal of the Geological Society, v. 167, p. 229-248, doi:10.1144/0016 $-76492009-072$.

Hazen, R.M., and Ferry, J.M., 2010, Mineral evolution: mineralogy in the fourth dimension: Elements, v. 6, p. 9-12, doi:10.2113/gselements.6.1.9.

Hazen, R.M., Papineau, D., Bleeker, W., Downs, R.T., Ferry, J.M., McCoy, T.J., Sverjensky, D.A., and Yang, H., 2008, Mineral evolution: American Mineralogist v. 93, p. 1693-1720, doi:10.2138/am.2008.2955.

Hazen, R.M., Bekker, A., Bish, D.L., Bleeker, W., Downs, R.T., Farquhar, J., Ferry, J.M., Grew, E.S., Knoll, A.H., Papineau, D.F., et al., 2011, Needs and opportunities in mineral evolution research: American Mineralogist v. 96, p. 953-963, doi:10.2138/am.2011.3725.

Henderson, C.M.B., Richardson, F.R., and Charnock, J.M., 2012, The Highwood mountains potassic igneous province, Montan $\equiv$ eral fractionation trends and magmatic processes revisited: Minil $\overline{\bar{r}}$ agazine (London), v. 76, p. 1005-1051, doi:10.1180/minmag.2012.076.4.16.

Herzberg, C.T., 1983, Liquidus and solidus temperatures and mineralogies for anhydrous garnet lherzolite to $15 \mathrm{GPa}$ : Physics of the Earth and Planetary Interiors, v. 32, p. 193-202, doi:10.1016/0031-9201(83)90139-5.

Herzberg, C.T., and Gazel, E., 2009, Petrological evidence for secular cooling in mantle plumes: Nature, v. 458, p. 619-622, doi:10.1038/nature07857.

Herzberg, C.T., and O'Hara, M.J., 1985, Origin of mantle peridotite and komatiite by partial melting: Geophysical Research Letters, v. 12, p. 541-544, doi:10.1029/GL012i009p00541.

Herzberg, C.T., and Rudnick, R., 2012, Formation of cratonic lithosphere: an integrated thermal and petrological model: Lithos, doi:10.1016/j lithos.2012.01.010.

Hess, H.H., 1960, Stillwater Igneous Complex, Montana: A Qualitative Mineralogical Study: Geological Society of America Memoir 80, 230 p.

Hess, P.C., 1989, Origin of igneous rocks: Cambridge, Massachusetts, Harvard University Press, $336 \mathrm{p}$.

Hildreth, W., 1979, The Bishop tuff: Evidence for the origin of Compositional zonation in silicic magma chambers, in Chapin, C.E., and Elston, W.E., eds., Ash-Flow Tuffs: Geological Society of America Special Paper 180, p. 43-75.

Hofmann, A.W., 2003, Sampling mantle heterogeneity through oceanic basalts: Isotopes and trace elements: Treatise on Geochemistry, Elsevier, v. 2, no. 03 , p. 1-44.

Hofmann, A.W., and White, W.M., 1982, Mantle plumes from ancient oceanic crust: Earth and Planetary Science Letters, v. 57, p. 421-436, doi:10.1016/0012-821X(82)90161-3

Holland, H.D., 1984, The chemical evolution of the atmosphere and ocean: Princeton, New Jersey, Princeton University Press, Princeton Series in Geochemistry, 598 p.

Holland, H.D., 2002, Volcanic gases, black smokers, and the great oxidation event: Geochimica et Cosmochimica Acta, v. 66, p. 3811-3826, doi:10.1016/S0016-7037(02)00950-X.

Huang, F., Lundstrom, C.C., Glessner, J., Ianno, A., Boudreau, A., Li, J., Ferre, E.C., Marshak, S., and DeFrates, J., 2009, Chemical and isotopic fractionation of wet andesite in a temperature gradient: experiments and models suggesting a new mechanism of magma differentiation: Geochimica et Cosmochimica Acta, v. 73, p. 729-749, doi:10.1016/j.gca.2008.11.012.

Huang, W.L., and Wyllie, P.J., 1973, Melting relations of muscovite-granite to $35 \mathrm{kbar}$ as a model for fusion of metamorphosed subducted oceanic sediments: Contributions to Mineralogy and Petrology, v. 42, p. 1-14, doi:10.1007/BF00521643

Huang, W.L., and Wyllie, P.J., 1981, Phase relations of S-type granite with $\mathrm{H}_{2} \mathrm{O}$ to 35 kbar: muscovite granite from Harney Peak, South Dakota: Journal of Geophysical Research, v. 86, p. 10515-10529, doi:10.1029/ JB086iB11p10515.

Ito, E., 1977, Absence of oxide mixture in high-pressure phases of $\mathrm{Mg}$ silicates: Geophysical Research Letters, v. 4, p. 72-74, doi:10.1029/ GL004i002p00072.

Ito, E., 2012, Development of the Kawai-type multi-anvil apparatus (KMA) and its application to high pressure Earth science: Journal of Physics, Conference Series, v. 377, doi:10.1088/1742-6596/377/1/012001. 
Ito, E., and Takahashi, E., 1989, Postspinel transformations in the system $\mathrm{Mg}_{2} \mathrm{SiO}_{4}-\mathrm{Fe}_{2} \mathrm{SiO}_{4}$ and some geophysical implications: Journal of Geophysical Research, v. 94, p. 10637-10646, doi:10.1029/JB094iB08p10637.

Ito, E., and Yamada, H., 1982, Stability relations of silicate spinels ilmenites and perovskites, in Manghani, M.H., and Akimoto, S., eds., High Pressure Research in Geophysics: New York, Academic Press, p. 405-420.

Ito, E., Akaogi, M., Topor, L., and Navrotsky, A., 1990, Negative pressure-temperature slopes for reactions forming $\mathrm{MgSiO}_{3}$ perovskite from calorimetry: Science, v. 249, p. 1275-1278, doi:10.1126/science.249.4974.1275.

Jagoutz, E., Palme, H., Baddenhausen, H., Blum, K., Cendales, K., Driebus, G., Spettel, B., Lorenz, V., and Wanke, H., 1979, The abundances of major, minor, and trace elements in the Earth's mantle from primitive ultramafic nodules, in Proceedings, $10^{\text {th }}$ Lunar and Planetary Science Conference, p. 2031-2050.

James, O.B., 1973, Crystallization history of lunar feldspathic basalt 14310: U.S. Geological Survey Professional Paper 841, p. 1-29.

Johannsen, A., 1939, A descriptive petrography of the igneous rocks, 2nd ed., V 1-4: Chicago, Illinois, University of Chicago Press.

Johnson, M.C., and Plank, T., 1999, Dehydration and melting experiments constrain the fate of subducted sediments: Geochemistry, Geophysics, Geosystems, v. 1, doi:10.1029/1999GC000014.

Jones, J.H., and Malvin, D.J., 1990, A nonmetal interaction model for the segregation of trace metals during solidification of Fe-Ni-S, Fe-Ni-P, and Fe-Ni-S-P alloys: Metal: Trans. B, v. 21B, p. 697-706, doi:10.1007/ BF02654248.

Jordan, T.H., 1988, Structure and formation of the continental tectosphere: Journal of Petrology Special Volume, p. 11-38.

Kato, T., and Kumazawa, M., 1985, Garnet phase of $\mathrm{MgSiO}_{3}$ filling the pyroxene-limenite gap at very high temperature: Nature, v. 316, p. 803-805, doi:10.1038/316803a0.

Katsura, T., and Ito, E., 1989 , The system $\mathrm{Mg}_{2} \mathrm{SiO}_{4}-\mathrm{Fe}_{2} \mathrm{SiO}_{4}$ at high pressures and temperatures: precise determination of stabilities of olivine, modified spinel, nd spinel: Journal of Geophysical Research, v. 94, B11, p. 15663 15670, doi:10.1029/JB094iB11p15663.

Kawai, N., and Endo, S., 1970, The generation of hydrostatic ultrahigh pressure by a split sphere apparatus: The Review of Scientific Instruments, v. 4, p. $425-428$.

Kawai, N., Tachimori, M., and Ito, E., 1974, A high pressure hexagonal form of $\mathrm{MgSiO}_{3}$ : Proceedings of the Japan Academy, v. 50, p. 378-380.

Kelemen, P.B., Shimizu, N., and Salters, V.J.M., 1995, Extraction of mid-ocean ridge basalt from the upwelling mantle by focused flow of melt in dunite channels: Nature, v. 375, p. 747-753, doi:10.1038/375747a0.

Kelemen, P.B., Hart, S.R., and Bernstein, S., 1998, Silica enrichment in the continental upper mantle via melt/rock reaction: Earth and Planetary Science Letters, v. 164, p. 387-406, doi:10.1016/S0012-821X(98)00233-7.

Kennedy, G.C., 1955, Some aspects of the role of water in rock melts, in Poldervaart, A. ed., Crust of the Earth (A Symposium): Geological Society of America Special Paper 62, p. 489-503.

Kessel, R., Schmidt, M.W., Ulmer, P., and Pettke, T., 2005, Trace element signature of subduction zone fluids, melts and supercritical liquids at 120 180 km depth: Nature, v. 437, p. 724-727, doi:10.1038/nature03971.

Kinzler, R.J., and Grove, T.L., 1992a, Primary magmas of mid-ocean ridge basalts, I: Experiments and methods: Journal of Geophysical Research, v. 97, p. 6885-6906, doi:10.1029/91JB02840.

Kinzler, R.J., and Grove, T.L., 1992b, Primary magmas of mid-ocean ridge basalts, 2: Applications: Journal of Geophysical Research, v. 97, p. 69076926, doi:10.1029/91JB02841.

Klein, E.M., and Langmuir, C.H., 1987, Global correlation of ocean ridge basalt chemistry with axial depth and crustal thickness: Journal of Geophysical Research, v. 92, p. 8089-8115, doi:10.1029/JB092iB08p08089.

Kleine, T., Munker, C., Mezger, K., and Palme, H., 2002, Rapid accretion and early core formation on asteroids and the terrestrial planets from Hf-W chronometry: Nature, v. 418, p. 952-955, doi:10.1038/nature00982.

Klimm, K., Blundy, J., and Green, T.H., 2008, Trace element partitioning and accessory phase saturation during $\mathrm{H}_{2} \mathrm{O}$-saturated melting of basalt with implications for subduction zone chemical fluxes: Journal of Petrology, v. 49, p. 523-553, doi:10.1093/petrology/egn001.

Komabayashi, T., and Fei, Y., 2010, Internally consistent thermodynamic data base for iron to the Earth's core conditions: Journal of Geophysical Research, v. 115, p. B03202, doi:10.1029/2009JB006442.

Korenaga, J., 2006, Archaean geodynamics and the thermal evolution of Earth, in Benn, K., Mareschal, J.C., and Condie, K., eds., Archean geodynamic processes: Washington D.C., American Geophysical Union Geophysical Monograph 164, p. 7-32.

Kushiro, I., 1969, The system forsterite-diopside-silica with and without water at high pressures: American Journal of Science, v. 267A, p. 269-294.

Kushiro, I., 1972, The effect of water on the composition of magmas formed at high pressures: Journal of Petrology, v. 13, p. 311-334, doi:10.1093/ petrology/13.2.311.

Kushiro, I., 1973, Origin of some magmas in oceanic and circum oceanic regions: Tectonophysics, v. 17, p. 211-222, doi:10.1016/0040-1951(73)90003-6.

Lambert, I.B., and Wyllie, P.J., 1970, Melting in the deep crust and upper mantle and the nature of the low velocity layer: Physics of the Earth and Planetary Interiors, v. 3, p. 316-322, doi:10.1016/0031-9201 (70)90068-3.

Langmuir, C.H., Klein, E.M., and Plank, T., 1992, Petrological systematics of mid-ocean ridge basalts: constraints on melt generation beneath oceanic ridges, in Morgan, J.P., Blackman, D.K., and Sinton, J.M., eds., Mantle Flow and Melt Generation at Mid-Ocean Ridges: Washington, D.C., American Geophysical Union Geophysical Monograph 71, p. 183-280.

Larimer, J.W., and Anders, E., 1970, Chemical fractionations in meteoritesIII: Major element fractionations in chondrites: Geochimica et Cosmochimica Acta, v. 34, p. 367-387, doi:10.1016/0016-7037(70)90112-2.

Larsen, E.S., Hurlbut, C.S., Jr., Buie, B.F., and Burgess, C.H., 1941a, Igneous rocks of the Highwood Mountains Montana. Part VI. Mineralogy: Bulletin of the Geological Society of America, v. 52, p. 1841-1856.

Larsen, E.S., Hurlbut, C.S., Jr., Burgess, C.H., and Buie, B.F., 1941b, Igneous rocks of the Highwood Mountains Montana. Part VII. Petrology: Bulletin of the Geological Society of America, v. 52, p. 1857-1868.

Lee, T., Papanastassiou, D.A., and Wasserburg, G.J., 1976, Demonstration of ${ }^{26} \mathrm{Mg}$ excess in Allende and evidence for ${ }^{26} \mathrm{Al}$ : Geophysical Research Letters, v. 3, p. 109-112, doi:10.1029/GL003i002p00109.

Le Fort, P., 1981, Manaslu leucogranite: a collision zone signature of the Himalaya model for its genesis and emplacement: Journal of Geophysical Research, v. 86B, p. 10545-10568, doi:10.1029/JB086iB11p10545.

Lesher, C.E., and Walker, D., 1991, Thermal diffusion in petrology, in Ganguly, J., ed., Diffusion, atomic ordering, and mass transport: Advances in Physical Geochemistry 8, p. 396-351.

Lewis, R.S., Ming, T., Wacker, J.F., Anders, E., and Steel, E., 1987, Interstellar diamonds in meteorites: Nature, v. 326, p. 160-162, doi:10.1038/326160a0.

Li, J., and Fei, Y., 2003, Experimental constraints on core composition, in Carlson, R.W., ed., The mantle and core, Treatise on Geochemistry (H.D. Holland and K.K. Turekian, eds.): Oxford, UK: Elsevier-Pergamon, v. 2, no. 14 , p. $521-546$.

Li, J., Struzhkin, V.V., Mao, H.-k., Shu, J., Hemley, R.J., Fei, Y., Mysen, B., Dera, P., Prakapenka, V., and Shen, G., 2004, Electronic spin state of iron in lower mantle perovskite: Proceedings of the National Academy of Sciences of the United States of America, v. 101, p. 14027-14030, doi:10.1073/pnas.0405804101.

Li, J., Sturhahn, W., Jackson, J.M., Struzhkin, V.V., Lin, J.F., Zhao, J., Mao, H.K., and Shen, G., 2006, Pressure effect on the electronic structure of iron in $(\mathrm{Mg}, \mathrm{Fe})(\mathrm{Si}, \mathrm{Al}) \mathrm{O}_{3}$ perovskite: a combined synchrotron Mossbauer and X-ray emission spectroscopy study up to $100 \mathrm{GPa}$ : Physics and Chemistry of Minerals, v. 33, p. 575-585, doi:10.1007/s00269-006-0105-y.

Liebermann, R.C., 2011, Multi-anvil, high pressure apparatus: a half century of development and progress: High Pressure Research, p.1-40, http://dx.doi .org/10.1080/08957959.2011.618698.

Lin, J.-F., Struzhkin, V.V., Jacobsen, S.D., Hu, M.Y., Chow, P., Kung, J., Liu, H., Mao, H.-K., and Hemley, R.J., 2005, Spin transition of iron in magnesiowustite in the Earth's lower mantle: Nature, v. 436, p. 377-380, doi:10.1038/nature 03825

Lin, J.-F., Watson, H., Vanko, G., Alp, E.E., Prakapenka, V.B., Dera, P., Struzhkin, V.V., Kubo, A., Zhao, J., McCammon, C., and Evans, W.E., 2008 , Intermediate-spin ferrous iron in lowermost mantle post-perovskite and perovskite: Nature Geoscience, doi:10.1038/ngeo310.

Liu, L., 1975, The post-oxide phases of forsterite and enstatite: Geophysical Research Letters, v. 2, p. 417-419, doi:10.1029/GL002i010p00417.

Liu, L., 1976, The post-spinel phases of forsterite: Nature, v. 262, p. 770-772, doi:10.1038/262770a0.

Loiselle, M.C., and Wones, D.R., 1979, Characteristics and origin of anorogenic granites: Geological Society of America Abstracts with Programs, v. 11, p. 468.

Longhi, J., 1991, Comparative liquidus equilibria of hypersthene-normative basalts at low pressure: American Mineralogist v. 76, p. 785-800. 
Lord, H.C., III, 1965, Molecular equilibria and condensation in a solar nebula and cool stellar atmospheres: Icarus, v. 4, p. 279-288, doi:10.1016/00191035(65)90005-9.

Lovelock, J., 1995, The Ages of Gaia: A Biography of Our Living Earth: W.W. Norton \& Co., $288 \mathrm{p}$.

Lovering, J.F., 1958, The nature of the Mohorovičić discontinuity: Transactions, American Geophysical Union, v. 39, p. 947-955, doi:10.1029/ TR039i005p00947.

LSAPT (Lunar Sample Analysis Planning Team), 1970, Summary of Apollo 11 Lunar Science Conference: Science, v. 167, p. 449-451, doi:10.1126/ science.167.3918.449.

Lugmair, G.W., 1974, Sm-Nd ages: a new dating method: Meteoritics, v. 9, p. 369.

Maaloe, S., and Aoki, K., 1977, The major element composition of the upper mantle estimated from the composition of lherzolites: Contributions to Mineralogy and Petrology v. 63, p. 161-173, doi:10.1007/BF00398777.

Mao, Z., Lin, J.F., Scott, H.P., Watson, H.C., Prakapenka, V.B., Xiao, Y., Chow, P., and McCammon, C., 2011, Iron-rich perovskite in the Earth's lower mantle: Earth and Planetary Science Letters, v. 309, p. 179-184, doi:10.1016/j.epsl.2011.06.030.

Marsh, B.D., and Carmichael, I.S.E., 1974, Benioff zone magmatism: Journal of Geophysical Research, v. 79, p. 1196-1206, doi:10.1029/ JB079i008p01196.

Marvin, U.B., 1983, The discovery and initial characterization of Alan Hills 81005: the first lunar meteorite: Geophysical Research Letters, v. 10, p. 775-778, doi:10.1029/GL010i009p00775.

Marvin, U.B., Wood, J.A., and Dickey, J.S., 1970, Ca-Al-rich phases in the Allende meteorite: Earth and Planetary Science Letters, v. 7, p. 346-350, doi:10.1016/0012-821X(69)90048-X.

Mason, B., 1962, Meteorites: New York and London, John Wiley \& Sons, 274 p.

McCammon, C., Kantor, I., Nariygina, O., Roquette, J., Ponkratz, U., Sergueev, I., Mezouar, M., Prakapenka, V., and Dubrovinsky, L., 2008, Stable intermediate-spin ferrous iron in lower mantle perovskite: Nature Geoscience, doi:10.1038/ngeo309.

McCord, T.B., Adams, J.B., and Johnson, T.V., 1970, Asteroid Vesta: spectral reflectivity and compositional implications: Science, v. 168, p. 14451447, doi:10.1126/science.168.3938.1445

McDonough, W.F., 2003, Compositional model for the Earth's core: Treatise on Geochemistry, v. 2, no. 15, p. 547-568, doi:10.1016/B0-08-043751 $-6 / 02015-6$.

McKenzie, D., and Bickle, M.J., 1988, The volume and composition of melt generated by extension of the lithosphere: Journal of Petrology, v. 29, p. 625-679, doi:10.1093/petrology/29.3.625.

McLennan, S.M., and Taylor, S.R., 1991, Sedimentary rocks and crustal evolution: tectonic setting and secular trends: The Journal of Geology, v. 99, p. 1-21, doi:10.1086/629470.

McSween, H.Y., 1994, What have we learned about Mars from the SNC meteorites?: Meteoritics, v. 29, p. 757-779.

Messenger, S., Keller, L.P., Stadermann, F.J., Walker, R.J., and Zinner, E., 2003, Samples of stars beyond the solar system: silicate grains in interplanetary dust: Science, v. 300, p. 105-108, doi:10.1126/science.1080576.

Miller, C.F., Wooden, J.F., Bennett, V.C., Wright, J.E., Solomon, G.C., and Hurst, R.W., 1990, Petrogenesis of the composite peraluminous-metaluminous Old Woman-Piute Range batholith, southeastern California; isotopic constraints, in Anderson, J.L., ed., The Nature and Origin of Cordilleran Magmatism: Geological Society of America Memoir 174, p. 99-109.

Miyashiro, A., Shido, F., and Ewing, M., 1969, Diversity and origin of abyssal tholeiite from the mid-Atlantic ridge near $24^{\circ}$ and $30^{\circ}$ north latitude: Contributions to Mineralogy and Petrology v. 23, p. 38-52, doi:10.1007/ BF00371331.

Morgan, W.J., 1971, Convection plumes in the lower mantle: Nature, v. 230, p. 42-43, doi:10.1038/230042a0.

Muir, I.D., Tilley, C.E., and Schoon, J.H., 1964, Basalts from the northern part of the rift zone of the mid-Atlantic ridge: Journal of Petrology, v. 5, p. 409-434, doi:10.1093/petrology/5.3.409.

Murakami, M., Hirose, K., Kawamura, K., Sata, N., and Ohishi, Y., 2004 Post-perovskite phase transition in $\mathrm{MgSiO}_{3}$ : Science, v. 304, p. 855-858, doi:10.1126/science.1095932

Nagashima, K., Krot, A.N., and Yurimoto, H., 2004, Stardust silicates from primitive meteorites: Nature, v. 428, p. 921-924, doi:10.1038/ nature 02510
Nesbitt, R.W., 1971, Skeletal crystal forms in the ultramafic rocks of the Yilgarn block, western Australia: evidence for an Archean ultramafic liquid: Geological Society of Australia Special Publication, v. 3, p. 331-347.

Nguyen, A.N., and Zinner, E., 2004, Discovery of ancient silicate stardust in a meteorite: Science, v. 303, p. 1496-1499, doi:10.1126/science.1094389.

Niu, Y., and O'Hara, M.J., 2008, Global correlations of ocean ridge basalt chemistry with axial depth: a new perspective: Journal of Petrology, v. 49, p. 633-664, doi:10.1093/petrology/egm051.

Nisbet, E.G., 1987, The young Earth: an introduction to Archaean geology: London, Allen and Unwin, 402 p.

Nyquist, L., Wooden, J., Bansal, B., Weismann, H., McKay, G., and Bogard, D., 1979, Rb-Sr age of the Shergotty achondrite: implications for metamorphic resetting of isochron ages: Geochimica et Cosmochimica Acta, v. 43, p. 1057-1074, doi:10.1016/0016-7037(79)90094-2.

Oganov, A.R., and Ono, S., 2004, Theoretical and experimental evidence for a post-perovskite phase of $\mathrm{MgSiO}_{3}$ in Earth's D" layer: Nature, v. 430, p. $445-448$, doi: 10.1038 /nature 02701 .

O'Hara, M.J., 1968a, The bearing of phase equilibrium studies in synthetic and natural systems on the origin and evolution of basic and ultrabasic rocks: EarthScience Reviews, v. 4, p. 69-133, doi:10.1016/0012-8252(68)90147-5.

O'Hara, M.J., 1968b, Are ocean floor basalts primary magmas?: Nature, v. 220, p. 683-686, doi:10.1038/220683a0.

O'Hara, M.J., 1977, Geochemical evolution during fractional crystallization of a periodically refilled magma chamber: Nature, v. 266, p. 503-507, doi:10.1038/266503a0.

Ohtani, E., 1985, The primordial terrestrial magma ocean and its implication for stratification of the mantle: Physics of the Earth and Planetary Interiors, v. 38, p. 70-80, doi:10.1016/0031-9201(85)90123-2.

Ohtani, E., Okada, Y., Kagawa, N., and Nagata, Y., 1987, Development of a new guide block system and high-pressure high temperature generation, 28th High Pressure Conference of Japan, 4-6 November, Kobe, Japan.

Ohtani, E., Kagawa, N., and Fujino, K., 1991, Stability of majorite (Mg,Fe) $\mathrm{SiO}_{3}$ at high pressures and $1800{ }^{\circ} \mathrm{C}$ : Earth and Planetary Science Letters, v. 102, p. 158-166, doi:10.1016/0012-821X(91)90005-3.

Oldham, R.D., 1906, The constitution of the interior of the Earth as revealed by earthquakes: Quarterly Transactions of the Geological Society of London, v. 62 , p. $459-486$

O'Neill, H.S.C., and Jenner, F.E., 2012, The global pattern of trace-element distributions in ocean floor basalts: Nature, v. 491, p. 698-704, doi:10.1038/ nature 11678.

Osborn, E.F., 1959, Role of oxygen pressure in the crystallization and differentiation of basaltic magma: American Journal of Science, v. 257, p. 609647, doi:10.2475/ajs.257.9.609.

Papanastassiou, D.A., and Wasserburg, G.J., 1968, Initial strontium isotopic abundances and the resolution of small time differences in the formation of planetary objects: Earth and Planetary Science Letters, v. 5, p. 361376, doi:10.1016/S0012-821X(68)80066-4.

Park, Y., and Means, W.D., 1996, Direct observation of deformation processes in crystal mushes: Journal of Structural Geology, v. 18, p. 847-858, doi:10.1016/S0191-8141(96)80017-4.

Patchett, P.J., and Tatsumoto, M., 1980, Lu-Hf total-rock isochron for the eucrite meteorites: Nature, v. 288, p. 571-574, doi:10.1038/288571a0.

Pernicka, E., and Wasson, J.T., 1987, Ru, Re, Os, Pt, and Au in iron meteorites: Geochimica et Cosmochimica Acta, v. 51, p. 1717-1726, doi:10.1016/0016-7037(87)90350-4.

Philpotts, A.R., and Ague, J.J., 2009, Principles of igneous and metamorphic petrology, 2nd ed.: New York, Cambridge University Press, 684 p.

Philpotts, J.A., and Schnetzler, C.C., 1970, Apollo 11 lunar samples: K, Rb, $\mathrm{Sr}, \mathrm{Ba}$, and rare earth concentrations in some rocks and separate phases: Proceedings, Apollo 11 Lunar Science Conference: Geochimica et Cosmochimica Acta, Suppl. 1, p. 1178-1194.

Plank, T., and Langmuir, C.H., 1988, An evaluation of the global variations in the major element chemistry of arc basalts: Earth and Planetary Science Letters, v. 90, p. 349-370, doi:10.1016/0012-821X(88)90135-5.

Plank, T., and Langmuir, C.H., 1993, Tracing trace elements from sediment input to volcanic output at subduction zones: Nature, v. 362, p. 739-743, doi:10.1038/362739a0.

Presnall, D.C., 1969, The geometrical analysis of partial fusion: American Journal of Science, v. 267, p. 1178-1194, doi:10.2475/ajs.267.10.1178.

Presnall, D.C., and Gudfinnsson, G.H., 2011, Oceanic volcanism from the low-velocity zone without mantle plumes: Journal of Petrology, v. 52, p. 1533-1546, doi:10.1093/petrology/egq093. 
Presnall, D.C., Dixon, J.R., O’Donnell, T.H., and Dixon, S.A., 1979, Generation of mid-ocean ridge tholeiites: Journal of Petrology, v. 20, p. 3-35, doi:10.1093/petrology/20.1.3.

Price, G.D., Putnis, A., Agrell, S.O., and Smith, D.G.W., 1983, Wadsleyite, natural $\beta-(\mathrm{Mg}, \mathrm{Fe})_{2} \mathrm{SiO}_{4}$ from the Peace River meteorite: Canadian Mineralogist, v. 21, p. 29-35.

Pyke, D.R., Naldrett A.J., and Eckstran, 1973, Archean ultramafic flows in Munro township, Ontario: Geological Society of America Bulletin, v. 84, p. 955-978, doi:10.1130/0016-7606(1973)84<955:AUFIMT>2.0.CO;2.

Rapp, R.P., and Watson, E.B., 1995, Dehydration melting of metabasalt at 8-32 kilobars: Implications for continental growth and crust-mantle recycling: Journal of Petrology, v. 36, p. 891-931, doi:10.1093/ petrology/36.4.891.

Rapp, R.P., Watson, E.B., and Miller, C.F., 1991, Partial melting of amphibolites/ eclogite and the origin of Archean trondjhemites and tonalites: Precambrian Research, v. 51, p. 1-25, doi:10.1016/0301-9268(91)90092-O.

Read, H.H., 1957, The granite controversy: geological addresses illustrating the evolution of a disputant: T. Murby publishing, $430 \mathrm{p}$.

Rigden, S.M., Ahrens, T.J., and Stolper, E.M., 1988, Shock compression of molten silicate: results for a model basaltic composition: Journal of Geophysical Research, v. 93, p. 367-382, doi:10.1029/JB093iB01p00367.

Ringwood, A.E., 1962, Prediction and confirmation of the olivine to spinel transition in $\mathrm{Ni}_{2} \mathrm{SiO}_{4}$ : Geochimica et Cosmochimica Acta, v. 26, p. 457-469, doi:10.1016/0016-7037(62)90090-X.

Ringwood, A.E., 1963, Olivine-spinel transformation in cobalt orthosilicate: Nature, v. 198, p. 79-80, doi:10.1038/198079a0.

Ringwood, A.E., and Major, A., 1966, Synthesis of $\mathrm{Mg}_{2} \mathrm{SiO}_{4}-\mathrm{Fe}_{2} \mathrm{SiO}_{4}$ spinel solid solutions: Earth and Planetary Science Letters, v. 1, p. 241-245, doi:10.1016/0012-821X(66)90077-X.

Roeder, P.L., and Emslie, R.F., 1970, Olivine-liquid equilibrium: Contributions to Mineralogy and Petrology v. 29, p. 275-289, doi:10.1007/BF00371276.

Shaw, H.R., Smith, R.L., and Hildreth, W., 1976, Thermogravitation mechanisms for chemical variations in zoned magma chambers: Geological Society of America Abstracts with Programs, v. 8, p. 1102.

Sherman, D.M., 1988, High-spin to low-spin transition of iron(II) oxides at high pressures: possible effects on the physics and chemistry of the lower mantle, in Ghose, S., Coey, J.M.D., and Salje, E., eds., Structural and magnetic phase transitions in minerals, vol 7: Berlin, Heidelberg, New York, Springer, p. 113-128.

Sidorin, I., Gurnis, M., Helmberger, D.V., and Ding, X., 1998, Interpreting $\mathrm{D}^{\prime \prime}$ seismic structure using synthetic waveforms computed from dynamic models: Earth and Planetary Science Letters, v. 163, p. 31-41, doi:10.1016/S0012-821X(98)00172-1.

Simon, S.B., 2012, The enduring legacy of the Allende meteorite: Elements, v. 8, p. $172-174$

Sisson, T.W., and Grove, T.L., 1993, Experimental investigation of the role of $\mathrm{H}_{2} \mathrm{O}$ in calc-alkaline differentiation and subduction zone magmatism: Contributions to Mineralogy and Petrology v. 113, p. 143-166, doi:10.1007/BF00283225.

Skora, S., and Blundy, J., 2010, High-pressure hydrous phase relations of radiolarian clay and implications for the involvement of subducted sediment in arc magmatism: Journal of Petrology, v. 51, p. 2211-2243, doi:10.1093/ petrology/egq054.

Sleep, N.H., 2000, Evolution of the mode of convection within terrestrial planets: Journal of Geophysical Research, v. 105, E7, p. 17563-17578, doi:10.1029/2000JE001240.

Smith, J.V., Anderson, A.T., Newton, R.C., Olsen, E.J., Wyllie, P.J., Crewe, A.V., Isaacson, M.S., and Johnson, D., 1970, Petrologic history of the Moon inferred from petrography, mineralogy, and petrogenesis of Apollo 11 rocks: Proceedings, Apollo 11 Lunar Science Conference, p. 897-925.

Sobolev, A.V., Hofmann, A.W., Sobolev, S.V., and Nikogosian, I.K., 2005, An olivine-free mantle source of Hawaiian shield basalts: Nature, v. 434, p. 590-597, doi:10.1038/nature03411.

Sobolev, A.V., Hofmann, A.W., Kuzmin, D.V., Yaxley, G.M., Arndt, N.T., Chung, S.-L., Danyushevsky, L.V., Elliot, T., Frey, F.A., Garcia, M.O., Gurenko, A.A., Kamenetsky, V.S., Kerr, A.C., Krivolutskaya, N.A., Matvienkov, V.V., Nikogosian, I.K., Rocholl, A., Sigurdsson, I.A., Sushchevskaya, N.M., and Teklay, M., 2007, The amount of recycled crust in sources of mantle-derived melts: Science, v. 316, p. 412-417.

Song, X., and Richards, P.G., 1996, Seismological evidence for differential rotation of the Earth's inner core: Nature, v. 382, p. 221-224, doi:10.1038/382221a0.
Spandler, C., Yaxley, G., Green, D.H., and Rosenthal, A., 2008, Phase relations and melting of anhydrous K-bearing eclogite from 1200 to $1600^{\circ} \mathrm{C}$ and 3 to 5 GPa: Journal of Petrology, v. 49, p. 771-795, doi:10.1093/petrology/ egm039.

Stern, C.R., and Wyllie, P.J., 1978, Phase compositions through crystallization intervals in basalt-andesite- $\mathrm{H}_{2} \mathrm{O}$ at $30 \mathrm{kbar}$ with implications for subduction zone magmatism: American Mineralogist, v. 63, p. 641-663.

Stolper, E.M., 1975, Petrogenesis of eucrite, howardite, and diogenite meteorites: Nature, v. 258, p. 220-222, doi:10.1038/258220a0.

Stolper, E.M., 1977, Experimental petrology of eucrite meteorites: Geochimica et Cosmochimica Acta, v. 41, p. 587-611, doi:10.1016/0016-7037 (77)90300-3.

Stolper, E.M., and McSween, H.Y., 1979, Petrology and origin of the shergottite meteorites: Geochimica et Cosmochimica Acta, v. 43, p. 1475-1498, doi:10.1016/0016-7037(79)90142-X.

Stolper, E.M., Walker, D., Hager, B.H., and Hays, J.F., 1981, Melt segregation from partially molten source region: the importance of melt density and source region size: Journal of Geophysical Research, v. 86, p. 6261-6271, doi:10.1029/JB086iB07p06261.

Stolper, E.M., McSween, H.Y., and Hays, J.F., 1979, A petrogenetic model of the relationships among achondritic meteorites: Geochimica et Cosmochimica Acta, v. 43, p. 589-602, doi:10.1016/0016-7037(79)90167-4.

Straub, S.M., Gomez-Tuena, A., Stuart, F.M., Zellmer, G.F., Espinasa-Perena, R., Cai, M.Y., and Iizuka, Y., 2011, Formation of hybrid arc andesites beneath thick continental crust: Earth and Planetary Science Letters, v. 303, p. 337-347, doi:10.1016/j.eps1.2011.01.013.

Takahashi, E., and Scarfe, C.M., 1985, Melting of peridotite to $14 \mathrm{GPa}$ and the genesis of komatiite: Nature, v. 315, p. 566-568, doi:10.1038/315566a0.

Thiemens, M.H., 1999, Mass-independent isotope effects in planetary atmospheres and the early Solar system: Science, v. 283, p. 341-345, doi:10.1126/science.283.5400.341.

Thiemens, M.H., and Heidenreich, J.E., III, 1983, The mass-independent fractionation of oxygen-a novel isotope effect and its possible cosmochemical implications: Science, v. 219, p. 1073-1075, doi:10.1126/ science.219.4588.1073.

Tormey, D.R., Grove, T.L., and Bryan, W.B., 1987, Experimental petrology of normal MORB near the Kane Fracture Zone: $22^{\circ}-25^{\circ} \mathrm{N}$, mid-Atlantic ridge: Contributions to Mineralogy and Petrology v. 96, p. 121-139, doi:10.1007/BF00375227.

Tuttle, O.F., and Bowen, N.L., 1958, Origin of granite in the light of experimental studies in the system $\mathrm{NaAlSi}_{3} \mathrm{O}_{8}-\mathrm{KAlSi}_{3} \mathrm{O}_{8}-\mathrm{SiO}_{2}-\mathrm{H}_{2} \mathrm{O}$ : Geological Society of America Memoir 74, $153 \mathrm{p}$.

Unruh, D.M., Nakamura, N., and Tatsumoto, M., 1977, History of the Pasamonte achondrite: relative susceptibility of the $\mathrm{Sm}-\mathrm{Nd}, \mathrm{Nd}-\mathrm{Sr}$, and $\mathrm{U}-\mathrm{Pb}$ systems to metamorphic events: Earth and Planetary Science Letters, v. 37 , p. $1-12$, doi:10.1016/0012-821X(77)90141-8.

Urey, H.C., 1952, The planets, their origin and development: Yale University Press, $245 \mathrm{p}$.

Van Schmus, W.R., and Wood, J.A., 1967, A chemical-petrologic classification for the chondritic meteorites: Geochimica et Cosmochimica Acta, v. 31, p. 747-765, doi:10.1016/S0016-7037(67)80030-9.

Verhoogen, J., 1954, Petrological evidence on temperature distribution in the mantle of the earth: Transactions, American Geophysical Union, v. 35, p. 85-92, doi:10.1029/TR035i001p00085.

Verhoogen J., 1965, Phase changes and convection in the Earth's mantle: Philosophical Transactions of the Royal Society of London, A 258, p. 276-283.

Verhoogen, J., 1973, Possible temperatures in the oceanic upper mantle and the formation of magma: Geological Society of America Bulletin, v. 84, p. 515-522, doi:10.1130/0016-7606(1973)84<515:PTITOU>2.0.CO;2.

Viljoen, M.J., and Viljoen, R.P., 1969, Evidence for the existence of a mobile extrusive peridotite magma from the Komatii formation of the Onverwacht Group: Geological Society of South Africa Special Publication, v. 2 , p. $87-112$.

Walker, D., 1983, Lunar and terrestrial crust formation: Proceedings, 14th Lunar and Planetary Science Conference, Pt. 1: Journal of Geophysical Research, v. 88, p. B17-B25, doi:10.1029/JB088iS01p00B17.

Walker, D., 1986, Melting equilibria in multicomponent systems and liquidus/ solidus convergence in mantle peridotite: Contributions to Mineralogy and Petrology v. 92, p. 303-307, doi:10.1007/BF00572158.

Walker, D., and DeLong, S.E., 1982, Soret separation of MORB magma: Contributions to Mineralogy and Petrology v. 79, p. 231-240, doi:10.1007/ BF00371514. 
Walker, D., Longhi, J., and Hays, J.F., 1972, Experimental petrology and origin of Fra Mauro rocks and soils: Proceedings, 3rd Lunar and Planetary Science Conference, p. 797-817.

Walker, D., Grove, T.L., Longhi, J., Stolper, E.M., and Hays, J.F., 1973, Origin of lunar feldspathic rocks: Earth and Planetary Science Letters, v. 20, p. 325-336, doi:10.1016/0012-821X(73)90006-X

Walker, D., Longhi, J., Stolper, E.M., Grove, T.L., and Hays, J.F., 1975, Origin of titaniferous lunar basalt: Geochimica et Cosmochimica Acta, v. 39, p. 1219-1235, doi:10.1016/0016-7037(75)90129-5.

Walker, D., Kirkpatrick, R.J., Longhi, J., and Hays, J.F., 1976, Crystallization history of lunar picritic basalt sample 12002: phase-equilibria and cooling rate studies: Geological Society of America Bulletin, v. 87, p. 646-656, doi:10.1130/0016-7606(1976)87<646:CHOLPB>2.0.CO;2.

Walker, D., Stolper, E.M., and Hays, J.F., 1979a, Basaltic volcanism: the importance of planet size, in Proceedings, 10th Lunar and Planetary Science Conference, 19-23 March, 1979, Houston, Texas: New York, Pergamon Press, Inc., v. 2, p. 1995-2015.

Walker, D., Shibata, T., and DeLong, S.E., 1979b, Abyssal tholeiites from the Oceanographer Fracture Zone: phase equilibria and mixing: Contributions to Mineralogy and Petrology v. 70, p. 111-125, doi:10.1007/ BF00374440.

Walker, D., Lesher, C.E., and Hays, J.F., 1981, Soret separation of lunar liquid: Proceedings, 12th Lunar and Planetary Science Conference, p. 991-999.

Walker, D., Carpenter, M.A., and Hitch, C.M., 1990, Some simplifications to multianvil devices for high pressure experiments: American Mineralogist v. 75 , p. 1020-1028.

Walter, M.J., 1998, Melting of garnet peridotite and the origin of komatiite and depleted lithosphere: Journal of Petrology, v. 39, p. 29-60, doi:10.1093/ petroj/39.1.29.

Walter, M.J., 2003, Melt extraction and compositional variation in mantle lithosphere: Treatise on Geochemistry, v. 2, p. 363-394, doi:10.1016/B0-08 -043751-6/02008-9.

Wang, Y., Walker, D., Chen, B.-H., and Scott, B.A., 1999, High-pressure synthesis of one-dimensional alkaline earth palladates: Journal of Alloys and Compounds, v. 285, p. 98-104, doi:10.1016/S0925-8388(99)00008-0.

Wark, D.A., and Lovering, J.F., 1977, Marker events in the early evolution of the solar system: evidence from the rims on Ca-Al-rich inclusions in carbonaceous chondrites: Proceedings, 8th Lunar and Planetary Science Conference: New York, Pergamon Press, p. 95-112.

Wasson, J.T., 1999, Trapped melt in IIIAB irons; solid/liquid elemental partitioning during the fractionation of the IIIAB magma: Geochimica et Cosmochimica Acta, v. 63, p. 2875-2889, doi:10.1016/S0016-7037(99)00283-5.
Wasson, J.T., Willis, J., Wai, C.M., and Kracher, A., 1980, Origin of iron meteorite groups IAB and IIICD: Z. Naturforschung, v. 35a, p. 781-795.

Watson, E.B., and Harrison, T.M., 2005, Zircon thermometer reveals minimum melting conditions on earliest: Earth Science, v. 308, p. 841-844.

White, A.J.R., and Chappell, B.W., 1983, Granitoid types and their distribution in the Lachlan fold belt, southeastern Australia, in Roddick, J.A., ed., Circum-Pacific plutonic terranes: Geological Society of America Memoir 159 , p. 21-34.

Wood, B.J., and Rubie, D.C., 1996, The effect of alumina on phase transformations at the 660-kilometer discontinuity from Fe-Mg partitioning experiments: Science, v. 273, p. 1522-1524, doi:10.1126/science.273.5281.1522.

Wood, J.A., 1964, The cooling rates and parent bodies of several iron meteorites: Icarus, v. 3, p. 429-459, doi:10.1016/0019-1035(64)90004-1.

Wood, J.A., Dickey, J.S., Jr., Marvin, U.B., and Powell, B.N., 1970, Lunar anorthosites and a geophysical model of the moon: Proceedings, Apollo 11 Lunar Science Conference, p. 965-988.

Wyllie, P.J., 1973, Experimental petrology and plate tectonics-a preview: Tectonophysics, v. 17, p. 189-209, doi:10.1016/0040-1951(73)90002-4.

Wyllie, P.J., and Huang, W.-L., 1975, Peridotite, kimberlite, and carbonatite explained in the system $\mathrm{CaO}-\mathrm{MgO}-\mathrm{SiO}_{2}-\mathrm{CO}_{2}$ : Geology, v. 3, p. 621-624, doi:10.1130/0091-7613(1975)3<621:PKACEI $>2.0$. CO;2.

Xiong, X., Keppler, H., Audetat, A., Ni, H., Sun, W., and Li, Y., 2011, Partitioning of $\mathrm{Nb}$ and $\mathrm{Ta}$ between rutile and felsic melt and the fractionation of $\mathrm{Nb} / \mathrm{Ta}$ during the partial melting of hydrous metabasalt: Geochimica et Cosmochimica Acta, v. 75, p. 1673-1692, doi:10.1016/j.gca.2010.06.039.

Yoder, H.S., Jr., and Tilley, C.E., 1962, Origin of basalt magmas: an experimental study of natural and synthetic rock systems: Journal of Petrology, v. 3, p. 342-532, doi:10.1093/petrology/3.3.342.

Yang, J., Goldstein, J.I., and Scott, E.D., 2008, Metallographic cooling rates and origin of IVA iron meteorites: Geochimica et Cosmochimica Acta, v. 72, p. 3043-3061, doi:10.1016/j.gca.2008.04.009.

Zen, E., 1988, Phase relations of peraluminous granitic rocks and their petrogenetic implications: Annual Review of Earth and Planetary Sciences, v. 16, p. 21-51, doi:10.1146/annurev.ea.16.050188.000321.

Zinner, E., 1998, Stellar nucleosynthesis and the isotopic composition of presolar grains from primitive meteorites: Annual Review of Earth and Planetary Sciences, v. 26, p. 147-188, doi:10.1146/annurev.earth.26.1.147.

Manuscript Accepted by the Society 6 December 2012 